\title{
Spirocyclizations involving oxonium ylides derived from cyclic $\alpha$-diazocarbonyl compounds: an entry into 6-oxa-2-azaspiro[4.5]decane scaffold
}

\author{
Dmitry Dar'in, ${ }^{* a}$ Grigory Kantin, ${ }^{a}$ Olga Bakulina, ${ }^{a}$ Anna Inyutina, ${ }^{a}$ Evgeny Chupakhin, ${ }^{a, b}$ \\ and Mikhail Krasavin**a,
}

${ }^{a}$ Saint Petersburg State University, Saint Petersburg, 199034 Russian Federation ${ }^{b}$ Immanuel Kant Baltic Federal University, Kaliningrad 236041 Russian Federation

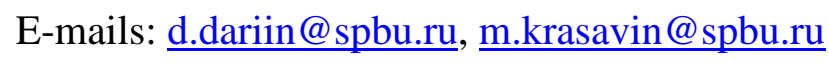

http://www.krasavin-group.org/

\section{Table of Contents}

I Crystallographic data for compounds $2 \mathrm{c}, 2 \mathrm{k}, \mathbf{2 r}, \mathbf{2 w},(S / R, S / R)-6 \mathbf{v}^{\text {maj }}$ and I. $(R / S, S / R)-6 v^{\min }$ S2

II. References S9

III. Copies of ${ }^{1} \mathrm{H},{ }^{13} \mathrm{C}$ NMR, ${ }^{19} \mathrm{~F}$ and NOESY spectra S10 
Crystallographic data for compounds $2 \mathrm{c}, 2 \mathrm{k}, 2 \mathrm{r}, 2 \mathrm{w},(S / R, S / R)-6 \mathrm{v}^{\mathrm{maj}}$ and $(R / S, S / R)-6 \mathrm{v}^{\mathrm{min}}$

X-ray Single Crystal analyses were performed on Agilent Technologies «Xcalibur» and «Supernova» diffractometers with monochromated MoK $\alpha$ or $\mathrm{CuK} \alpha$ radiation, respectively. Crystal growth was performed by slow evaporation of solution in $\mathrm{MeOH} / \mathrm{DCM}$ mixture $(2: 1)$ at $5{ }^{\circ} \mathrm{C}$. Crystals were measuring at the temperature of $100 \mathrm{~K}$ The structures has been solved by the Superflip ${ }^{1}$ and ShelXS ${ }^{2}$ structure solution programs using Charge Flipping and Direct Methods, respectively, and refined with the $\mathrm{ShelXL}^{3}$ refinement incorporated in the OLEX2 program package $^{4}$. CCDC \# 2032237 (2c), CCDC \# 2032235 (2k), CCDC \# 2032236 (2r), CCDC \#

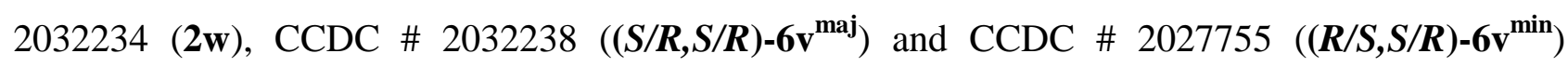
contain the supplementary crystallographic data for this paper. These data can be obtained free of charge from The Cambridge Crystallographic Data Centre via http://www.ccdc.cam.ac.uk. 


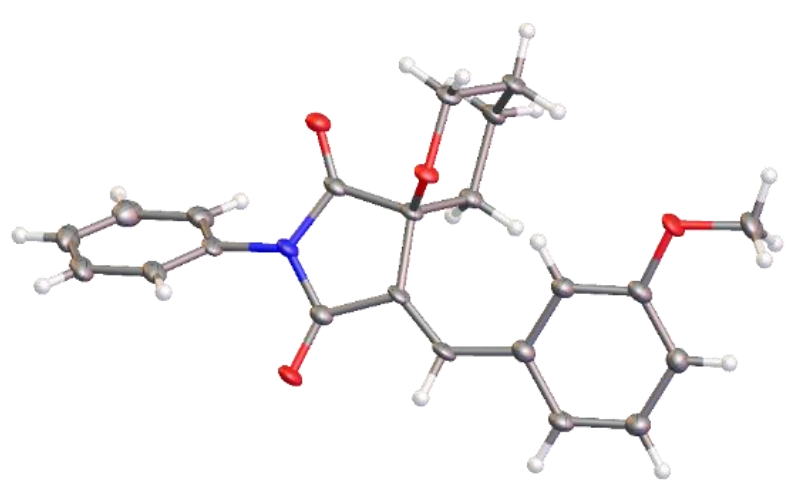

Figure S1. ORTEP representation of compound 2c (thermal ellipsoids are shown at $50 \%$ probability).

\begin{tabular}{|c|c|}
\hline \multicolumn{2}{|c|}{ Table S1. Crystal data and structure refinement for $\mathbf{2 c}$} \\
\hline Empirical formula & $\mathrm{C} 22 \mathrm{H} 21 \mathrm{NO} 4$ \\
\hline Formula weight & 363.40 \\
\hline Temperature/K & $100.00(10)$ \\
\hline Crystal system & monoclinic \\
\hline Space group & $\mathrm{P} 21 / \mathrm{n}$ \\
\hline $\mathrm{a} / \AA$ & $16.2411(4)$ \\
\hline $\mathrm{b} / \AA \AA$ & $5.5813(2)$ \\
\hline $\mathrm{c} / \AA \AA$ & $20.3860(5)$ \\
\hline$\alpha /^{\circ}$ & 90 \\
\hline$\beta /{ }^{\circ}$ & $106.766(3)$ \\
\hline$\gamma /{ }^{\circ}$ & 90 \\
\hline Volume $/ \AA^{3}$ & 1769.36(9) \\
\hline $\mathrm{Z}$ & 4 \\
\hline$\rho_{\text {calc }} \mathrm{g} / \mathrm{cm}^{3}$ & 1.364 \\
\hline$\mu / \mathrm{mm}^{-1}$ & 0.764 \\
\hline $\mathrm{F}(000)$ & 768.0 \\
\hline Crystal size $/ \mathrm{mm}^{3}$ & $0.12 \times 0.09 \times 0.04$ \\
\hline Radiation & $\mathrm{Cu} \mathrm{K \alpha}(\lambda=1.54184)$ \\
\hline $2 \Theta$ range for data collection ${ }^{\circ}$ & 6.162 to 141.092 \\
\hline Index ranges & $-19 \leq \mathrm{h} \leq 19,-6 \leq \mathrm{k} \leq 6,-24 \leq 1 \leq 24$ \\
\hline Reflections collected & 11704 \\
\hline Independent reflections & $3366[$ Rint $=0.0482$, Rsigma $=0.0459]$ \\
\hline Data/restraints/parameters & $3366 / 0 / 245$ \\
\hline Goodness-of-fit on $\mathrm{F}^{2}$ & 1.056 \\
\hline Final $\mathrm{R}$ indexes $[\mathrm{I}>=2 \sigma(\mathrm{I})]$ & $\mathrm{R} 1=0.0596, \mathrm{wR} 2=0.1552$ \\
\hline Final R indexes [all data] & $\mathrm{R} 1=0.0715, \mathrm{wR} 2=0.1662$ \\
\hline Largest diff. peak/hole / e $\AA^{-3}$ & $0.65 /-0.40$ \\
\hline \multicolumn{2}{|c|}{ CCDC 2032237} \\
\hline
\end{tabular}




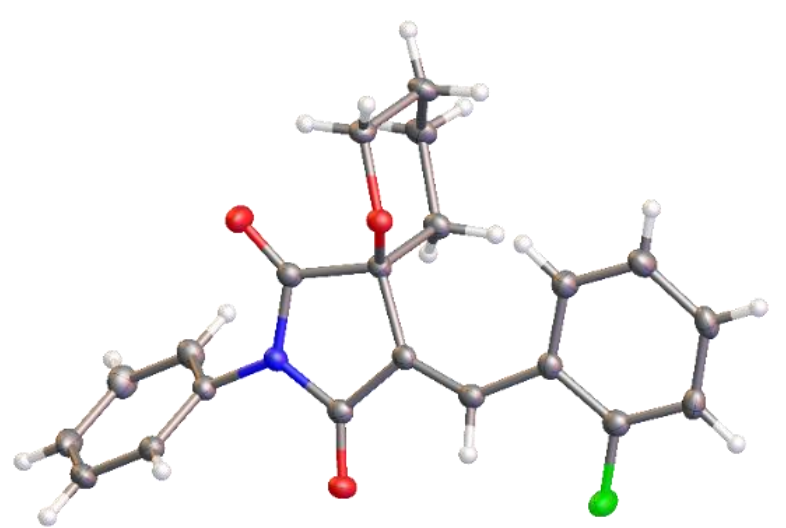

Figure S2. ORTEP representation of compound 2k (thermal ellipsoids are shown at $50 \%$ probability).

\begin{tabular}{|c|c|}
\hline \multicolumn{2}{|c|}{ Table S2. Crystal data and structure refinement for $\mathbf{2 k}$} \\
\hline Empirical formula & $\mathrm{C} 21 \mathrm{H} 18 \mathrm{NO} 3 \mathrm{~F}$ \\
\hline Formula weight & 351.36 \\
\hline Temperature/K & $100.00(10)$ \\
\hline Crystal system & triclinic \\
\hline Space group & $\mathrm{P}-1$ \\
\hline $\mathrm{a} / \AA ̊$ & $8.86500(10)$ \\
\hline $\mathrm{b} / \AA$ & $9.2249(2)$ \\
\hline $\mathrm{c} / \AA$ & $11.4276(2)$ \\
\hline$\alpha /{ }^{\circ}$ & $109.772(2)$ \\
\hline$\beta /{ }^{\circ}$ & $94.3680(10)$ \\
\hline$\gamma /{ }^{\circ}$ & $104.3340(10)$ \\
\hline Volume $/ \AA^{3}$ & $838.85(3)$ \\
\hline $\mathrm{Z}$ & 2 \\
\hline$\rho_{\text {calc }} \mathrm{g} / \mathrm{cm}^{3}$ & 1.391 \\
\hline$\mu / \mathrm{mm}^{-1}$ & 0.830 \\
\hline $\mathrm{F}(000)$ & 368.0 \\
\hline Crystal size $/ \mathrm{mm}^{3}$ & $0.18 \times 0.1 \times 0.05$ \\
\hline Radiation & $\mathrm{Cu} \mathrm{K} \alpha(\lambda=1.54184)$ \\
\hline $2 \Theta$ range for data collection $/{ }^{\circ}$ & 8.352 to 154.506 \\
\hline Index ranges & $-10 \leq \mathrm{h} \leq 11,-11 \leq \mathrm{k} \leq 11,-14 \leq 1 \leq 14$ \\
\hline Reflections collected & 28581 \\
\hline Independent reflections & $3493[$ Rint $=0.1138$, Rsigma $=0.0470]$ \\
\hline Data/restraints/parameters & $3493 / 0 / 235$ \\
\hline Goodness-of-fit on $\mathrm{F}^{2}$ & 1.100 \\
\hline Final $\mathrm{R}$ indexes $[\mathrm{I}>=2 \sigma(\mathrm{I})]$ & $\mathrm{R} 1=0.0471, \mathrm{wR} 2=0.1350$ \\
\hline Final R indexes [all data] & $\mathrm{R} 1=0.0500, \mathrm{wR} 2=0.1380$ \\
\hline Largest diff. peak/hole / e $\AA^{-3}$ & $0.33 /-0.29$ \\
\hline \multicolumn{2}{|c|}{ CCDC 2032235} \\
\hline
\end{tabular}




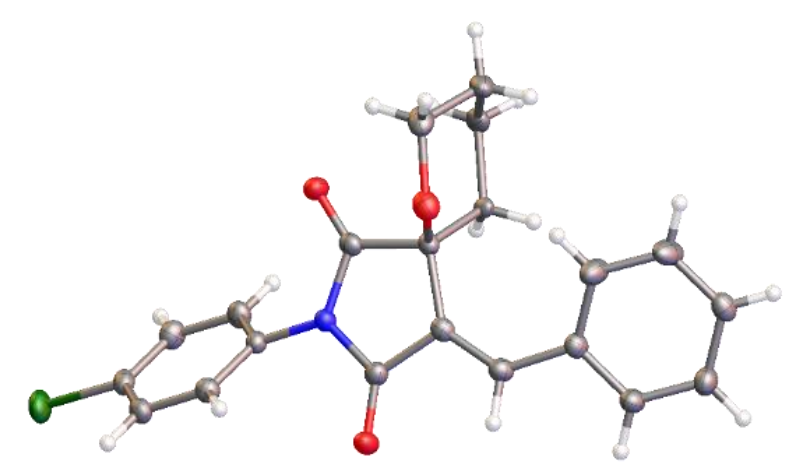

Figure S3. ORTEP representation of compound 2r (thermal ellipsoids are shown at $50 \%$ probability).

\begin{tabular}{|c|c|}
\hline \multicolumn{2}{|c|}{ Table S3. Crystal data and structure refinement for $\mathbf{2 r}$} \\
\hline Empirical formula & $\mathrm{C} 21 \mathrm{H} 18 \mathrm{ClNO} 3$ \\
\hline Formula weight & 367.81 \\
\hline Temperature/K & $100.00(10)$ \\
\hline Crystal system & monoclinic \\
\hline Space group & $\mathrm{P} 21 / \mathrm{n}$ \\
\hline $\mathrm{a} / \AA$ & $5.62620(10)$ \\
\hline $\mathrm{b} / \AA$ & $12.0230(3)$ \\
\hline $\mathrm{c} / \AA \AA$ & $25.1409(6)$ \\
\hline$\alpha /^{\circ}$ & 90 \\
\hline$\beta /{ }^{\circ}$ & $92.578(2)$ \\
\hline$\gamma /{ }^{\circ}$ & 90 \\
\hline Volume $/ \AA^{3}$ & 1698.91(7) \\
\hline $\mathrm{Z}$ & 4 \\
\hline$\rho_{\text {calc }} \mathrm{g} / \mathrm{cm}^{3}$ & 1.438 \\
\hline$\mu / \mathrm{mm}^{-1}$ & 2.172 \\
\hline $\mathrm{F}(000)$ & 768.0 \\
\hline Crystal size $/ \mathrm{mm}^{3}$ & $0.11 \times 0.08 \times 0.06$ \\
\hline Radiation & $\mathrm{Cu} \mathrm{K \alpha}(\lambda=1.54184)$ \\
\hline $2 \Theta$ range for data collection $/{ }^{\circ}$ & 7.04 to 154.22 \\
\hline Index ranges & $-7 \leq \mathrm{h} \leq 4,-15 \leq \mathrm{k} \leq 15,-31 \leq 1 \leq 31$ \\
\hline Reflections collected & 22343 \\
\hline Independent reflections & $3530[$ Rint $=0.0487$, Rsigma $=0.0256]$ \\
\hline Data/restraints/parameters & $3530 / 0 / 235$ \\
\hline Goodness-of-fit on $\mathrm{F}^{2}$ & 1.170 \\
\hline Final $R$ indexes $[\mathrm{I}>=2 \sigma(\mathrm{I})]$ & $\mathrm{R} 1=0.0552, \mathrm{wR} 2=0.1234$ \\
\hline Final R indexes [all data] & $\mathrm{R} 1=0.0572, \mathrm{wR} 2=0.1243$ \\
\hline Largest diff. peak/hole / e $\AA^{-3}$ & $0.47 /-0.33$ \\
\hline \multicolumn{2}{|c|}{ CCDC 2032236} \\
\hline
\end{tabular}




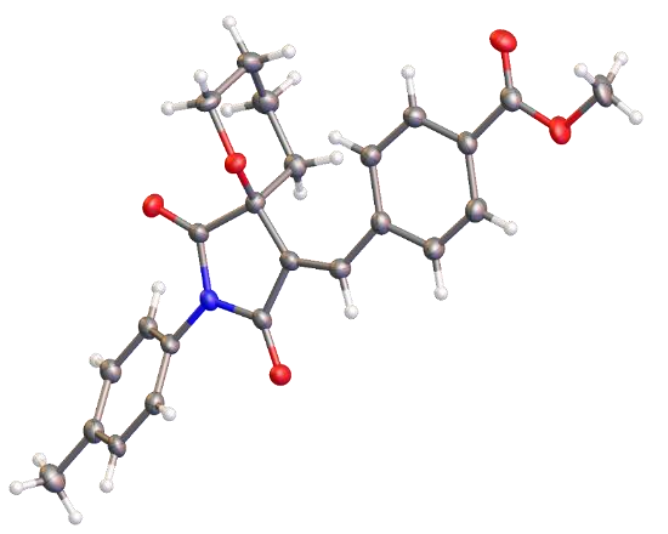

Figure S4. ORTEP representation of compound $\mathbf{2 w}$ (thermal ellipsoids are shown at $50 \%$ probability).

\begin{tabular}{|c|c|}
\hline \multicolumn{2}{|c|}{ Table S4. Crystal data and structure refinement for $\mathbf{2 w}$} \\
\hline Empirical formula & $\mathrm{C} 24 \mathrm{H} 23 \mathrm{NO} 5$ \\
\hline Formula weight & 405.43 \\
\hline Temperature/K & $100.00(10)$ \\
\hline Crystal system & triclinic \\
\hline Space group & $\mathrm{P}-1$ \\
\hline $\mathrm{a} / \AA$ & $12.0824(3)$ \\
\hline $\mathrm{b} / \AA \AA$ & $13.2365(3)$ \\
\hline $\mathrm{c} / \AA \AA$ & $14.8059(3)$ \\
\hline$\alpha /^{\circ}$ & $64.555(2)$ \\
\hline$\beta /{ }^{\circ}$ & $71.958(2)$ \\
\hline$\gamma /{ }^{\circ}$ & $74.726(2)$ \\
\hline Volume $/ \AA^{3}$ & 2009.49(9) \\
\hline $\mathrm{Z}$ & 4 \\
\hline$\rho_{\text {calc }} \mathrm{g} / \mathrm{cm}^{3}$ & 1.340 \\
\hline$\mu / \mathrm{mm}^{-1}$ & 0.769 \\
\hline $\mathrm{F}(000)$ & 856.0 \\
\hline Crystal size $/ \mathrm{mm}^{3}$ & $0.9 \times 0.6 \times 0.4$ \\
\hline Radiation & $\mathrm{Cu} \mathrm{K} \alpha(\lambda=1.54184)$ \\
\hline $2 \Theta$ range for data collection $/^{\circ}$ & 6.786 to 155.408 \\
\hline Index ranges & $-15 \leq \mathrm{h} \leq 15,-16 \leq \mathrm{k} \leq 14,-18 \leq 1 \leq 18$ \\
\hline Reflections collected & 81542 \\
\hline Independent reflections & $8372[$ Rint $=0.0863$, Rsigma $=0.0366]$ \\
\hline Data/restraints/parameters & $8372 / 0 / 545$ \\
\hline Goodness-of-fit on $\mathrm{F}^{2}$ & 1.021 \\
\hline Final $\mathrm{R}$ indexes $[\mathrm{I}>=2 \sigma(\mathrm{I})]$ & $\mathrm{R} 1=0.0471, \mathrm{wR} 2=0.1418$ \\
\hline Final R indexes [all data] & $\mathrm{R} 1=0.0871, \mathrm{wR} 2=0.1737$ \\
\hline Largest diff. peak/hole / e $\AA^{-3}$ & $0.23 /-0.27$ \\
\hline
\end{tabular}




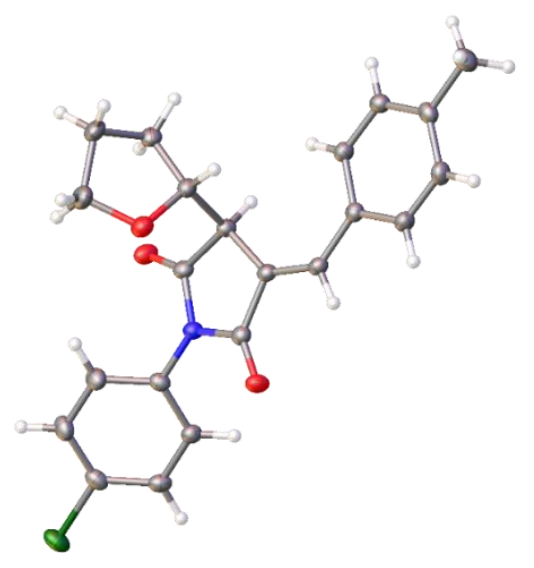

Figure S5. ORTEP representation of compound $(\boldsymbol{S} / \boldsymbol{R}, \boldsymbol{S} / \boldsymbol{R})-\mathbf{6} \mathbf{v}^{\text {maj }}$ (thermal ellipsoids are shown at 50\% probability).

\begin{tabular}{|c|c|}
\hline \multicolumn{2}{|c|}{ Table S5. Crystal data and structure refinement for $(S / R, S / R)-6 v^{\text {maj }}$} \\
\hline Empirical formula & $\mathrm{C} 22 \mathrm{H} 20 \mathrm{ClNO} 3$ \\
\hline Formula weight & 381.84 \\
\hline Temperature/K & $100.00(10)$ \\
\hline Crystal system & monoclinic \\
\hline Space group & $\mathrm{P} 21 / \mathrm{n}$ \\
\hline $\mathrm{a} / \AA$ & $8.7458(2)$ \\
\hline $\mathrm{b} / \AA$ & $19.7502(4)$ \\
\hline $\mathrm{c} / \AA$ & $11.0676(2)$ \\
\hline$\alpha /^{\circ}$ & 90 \\
\hline$\beta /{ }^{\circ}$ & $104.068(2)$ \\
\hline$\gamma /{ }^{\circ}$ & 90 \\
\hline Volume $/ \AA^{3}$ & $1854.38(7)$ \\
\hline $\mathrm{Z}$ & 4 \\
\hline$\rho_{\text {calc }} \mathrm{g} / \mathrm{cm}^{3}$ & 1.368 \\
\hline$\mu / \mathrm{mm}^{-1}$ & 2.009 \\
\hline $\mathrm{F}(000)$ & 800.0 \\
\hline Crystal size $/ \mathrm{mm}^{3}$ & $0.14 \times 0.12 \times 0.05$ \\
\hline Radiation & $\mathrm{Cu} \mathrm{K} \alpha(\lambda=1.54184)$ \\
\hline $2 \Theta$ range for data collection $/{ }^{\circ}$ & 8.954 to 140.972 \\
\hline Index ranges & $-10 \leq \mathrm{h} \leq 10,-24 \leq \mathrm{k} \leq 21,-13 \leq 1 \leq 13$ \\
\hline Reflections collected & 22048 \\
\hline Independent reflections & $3556[$ Rint $=0.0503$, Rsigma $=0.0297]$ \\
\hline Data/restraints/parameters & $3556 / 0 / 245$ \\
\hline Goodness-of-fit on $\mathrm{F}^{2}$ & 1.050 \\
\hline Final $R$ indexes $[\mathrm{I}>=2 \sigma(\mathrm{I})]$ & $\mathrm{R} 1=0.0406, \mathrm{wR} 2=0.1018$ \\
\hline Final R indexes [all data] & $\mathrm{R} 1=0.0441, \mathrm{wR} 2=0.1042$ \\
\hline Largest diff. peak/hole / e $\AA^{-3}$ & $0.28 /-0.46$ \\
\hline \multicolumn{2}{|c|}{ CCDC 2032238} \\
\hline
\end{tabular}




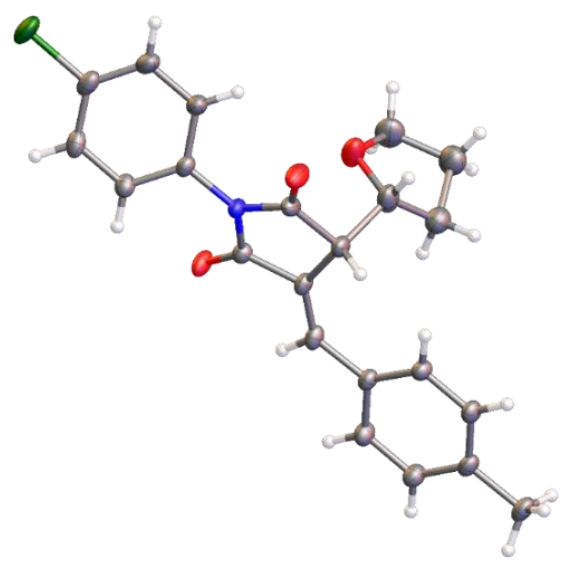

Figure S6. ORTEP representation of compound $(\boldsymbol{R} / \mathbf{S}, \mathbf{S} / \boldsymbol{R})-\mathbf{6} \mathbf{v}^{\mathbf{m i n}}$ (thermal ellipsoids are shown at 50\% probability).

\begin{tabular}{|c|c|}
\hline \multicolumn{2}{|c|}{ Table S6. Crystal data and structure refinement for $(R / S, S / R)-6 v^{\min }$} \\
\hline Empirical formula & $\mathrm{C} 22 \mathrm{H} 20 \mathrm{ClNO} 3$ \\
\hline Formula weight & 381.84 \\
\hline Temperature/K & $100.00(10)$ \\
\hline Crystal system & triclinic \\
\hline Space group & $\mathrm{P}-1$ \\
\hline $\mathrm{a} / \AA$ & $8.3269(3)$ \\
\hline $\mathrm{b} / \AA$ & $10.7684(3)$ \\
\hline $\mathrm{c} / \AA \AA$ & $11.0047(4)$ \\
\hline$\alpha /^{\circ}$ & $70.283(3)$ \\
\hline$\beta /{ }^{\circ}$ & $82.873(3$ \\
\hline$\gamma /{ }^{\circ}$ & $81.861(3)$ \\
\hline Volume $/ \AA^{3}$ & $916.46(5)$ \\
\hline $\mathrm{Z}$ & 2 \\
\hline$\rho_{\text {calc }} \mathrm{g} / \mathrm{cm}^{3}$ & 1.384 \\
\hline$\mu / \mathrm{mm}^{-1}$ & 2.033 \\
\hline $\mathrm{F}(000)$ & 400.0 \\
\hline Crystal size $/ \mathrm{mm}^{3}$ & $0.22 \times 0.18 \times 0.08$ \\
\hline Radiation & $\mathrm{Cu} \mathrm{K \alpha}(\lambda=1.54184)$ \\
\hline $2 \Theta$ range for data collection $/{ }^{\circ}$ & 8.564 to 140.85 \\
\hline Index ranges & $-8 \leq \mathrm{h} \leq 10,-13 \leq \mathrm{k} \leq 13,-13 \leq 1 \leq 13$ \\
\hline Reflections collected & 15962 \\
\hline Independent reflections & $3499[$ Rint $=0.0284$, Rsigma $=0.0204]$ \\
\hline Data/restraints/parameters & $3499 / 0 / 245$ \\
\hline Goodness-of-fit on $\mathrm{F}^{2}$ & 1.046 \\
\hline Final $\mathrm{R}$ indexes $[\mathrm{I}>=2 \sigma(\mathrm{I})]$ & $\mathrm{R} 1=0.0811, \mathrm{wR} 2=0.2022$ \\
\hline Final R indexes [all data] & $\mathrm{R} 1=0.0842, \mathrm{wR} 2=0.2046$ \\
\hline Largest diff. peak/hole / e $\AA^{-3}$ & $1.87 /-0.94$ \\
\hline & 2027755 \\
\hline
\end{tabular}




\section{References}

(1) Palatinus, L.; Chapuis, G. SUPERFLIP- a Computer Program for the Solution of Crystal Structures by Charge Flipping in Arbitrary Dimensions. J. Appl. Crystallogr. 2007, 40, 786790.

(2) Sheldrick, G. M. A Short History of $\{$ lit SHELX $\}$. Acta Crystallogr. Sect. A 2008, 64, 112122.

(3) Sheldrick, G. M. Crystal Structure Refinement with \{lit SHELXL\}. Acta Crystallogr. Sect. C 2015, 71, 3-8.

(4) Dolomanov, O. V; Bourhis, L. J.; Gildea, R. J.; Howard, J. A. K.; Puschmann, H. \{ lit OLEX2 \}: A Complete Structure Solution, Refinement and Analysis Program. J. Appl. Crystallogr. 2009, 42, 339-341. 
Copies of ${ }^{1} \mathrm{H}\left(400.13 \mathrm{MHz}, \mathrm{CDCl}_{3}\right)$ and ${ }^{13} \mathrm{C}\left(100.61 \mathrm{MHz}, \mathrm{CDCl}_{3}\right)$ spectra of $\mathbf{1 f}$
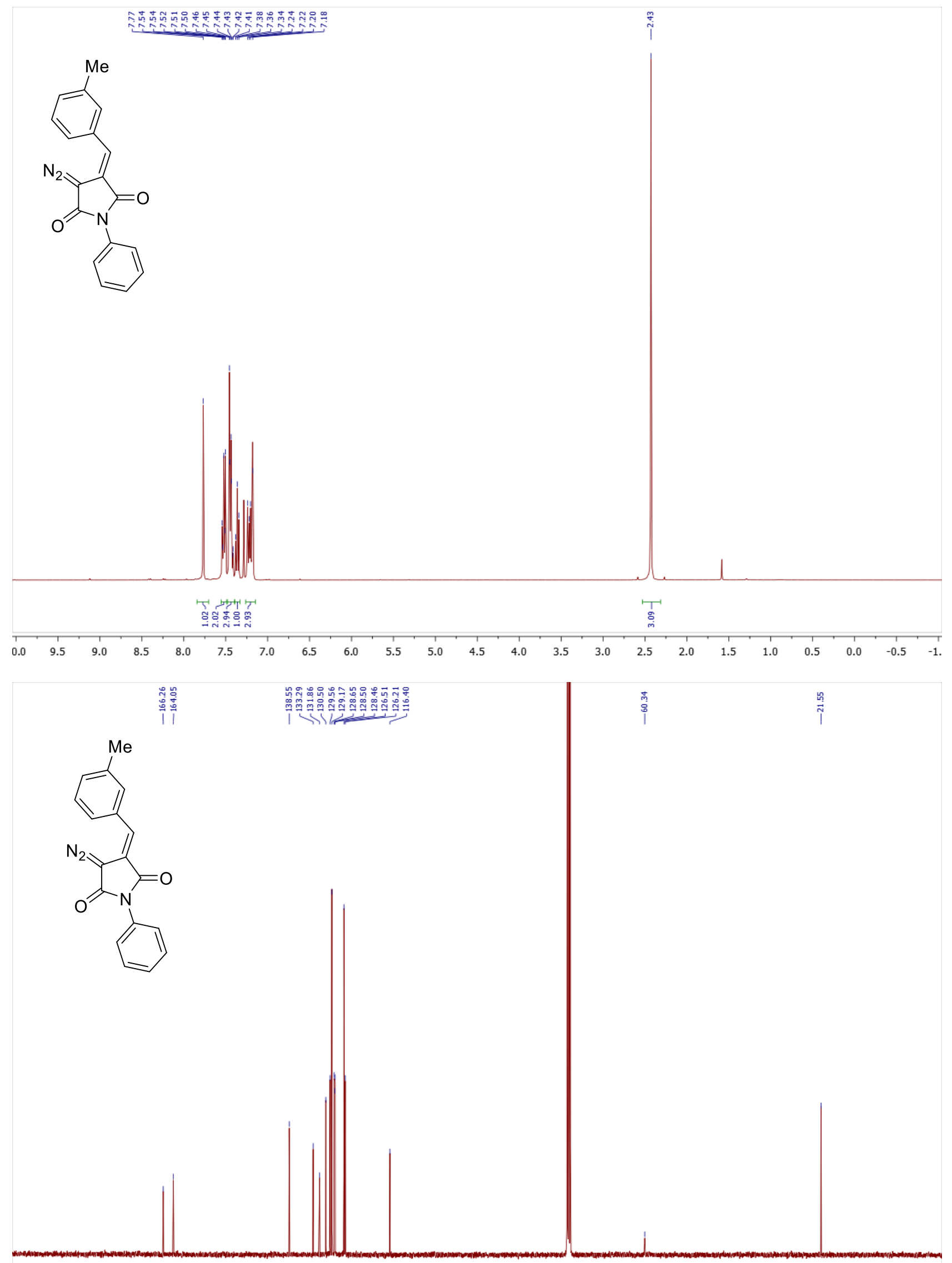

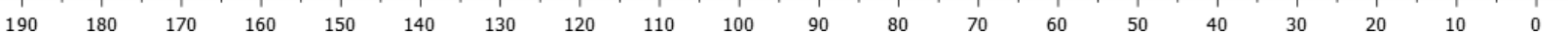


Copies of ${ }^{1} \mathrm{H}\left(400.13 \mathrm{MHz}, \mathrm{CDCl}_{3}\right)$ and ${ }^{13} \mathrm{C}\left(100.61 \mathrm{MHz}, \mathrm{CDCl}_{3}\right)$ spectra of $\mathbf{1 m}$
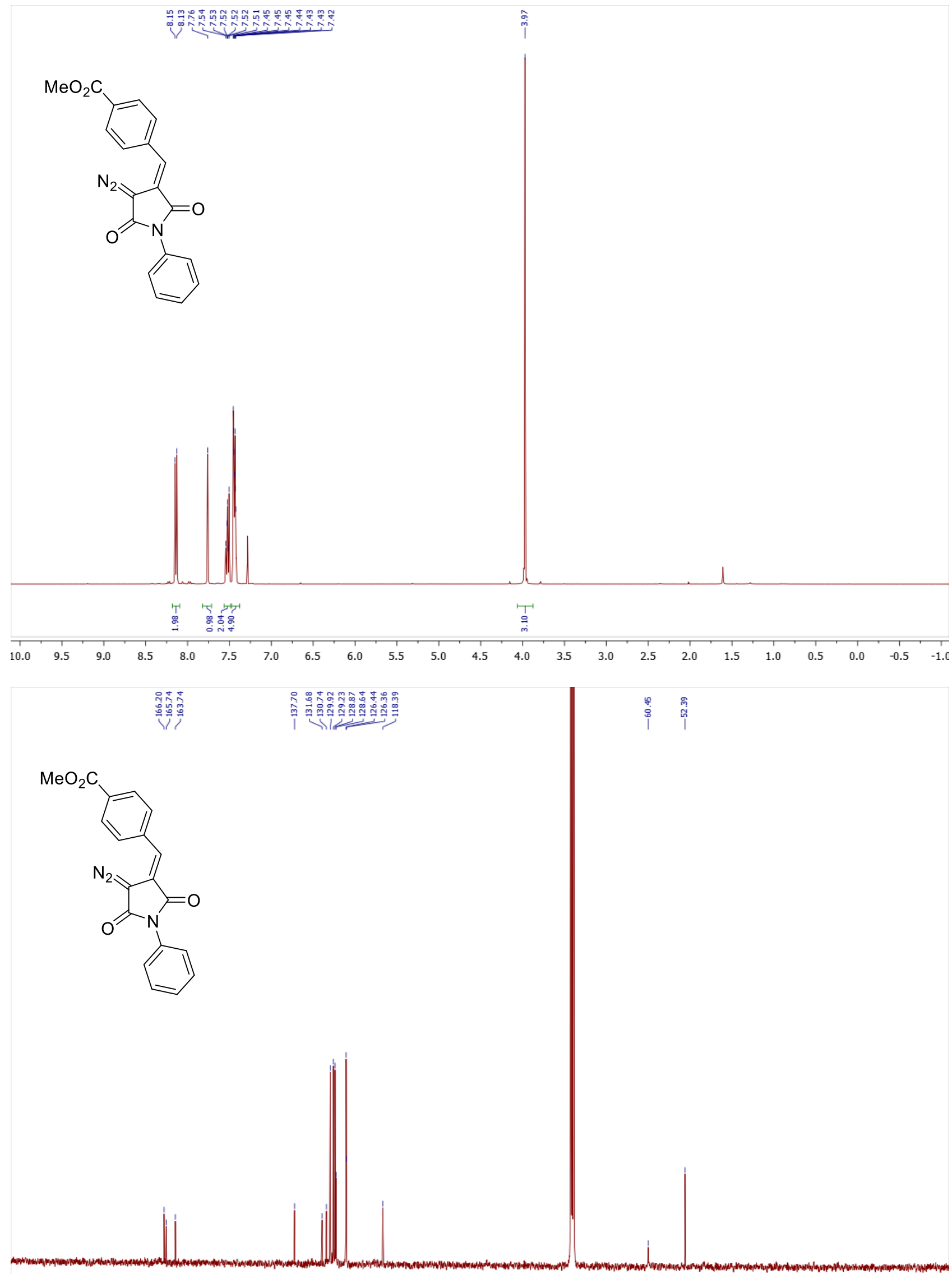

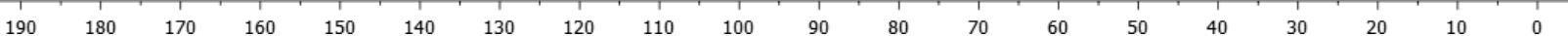


Copies of ${ }^{1} \mathrm{H}\left(400.13 \mathrm{MHz}, \mathrm{CDCl}_{3}\right)$ and ${ }^{13} \mathrm{C}\left(100.61 \mathrm{MHz}, \mathrm{CDCl}_{3}\right)$ spectra of $\mathbf{1 q}$

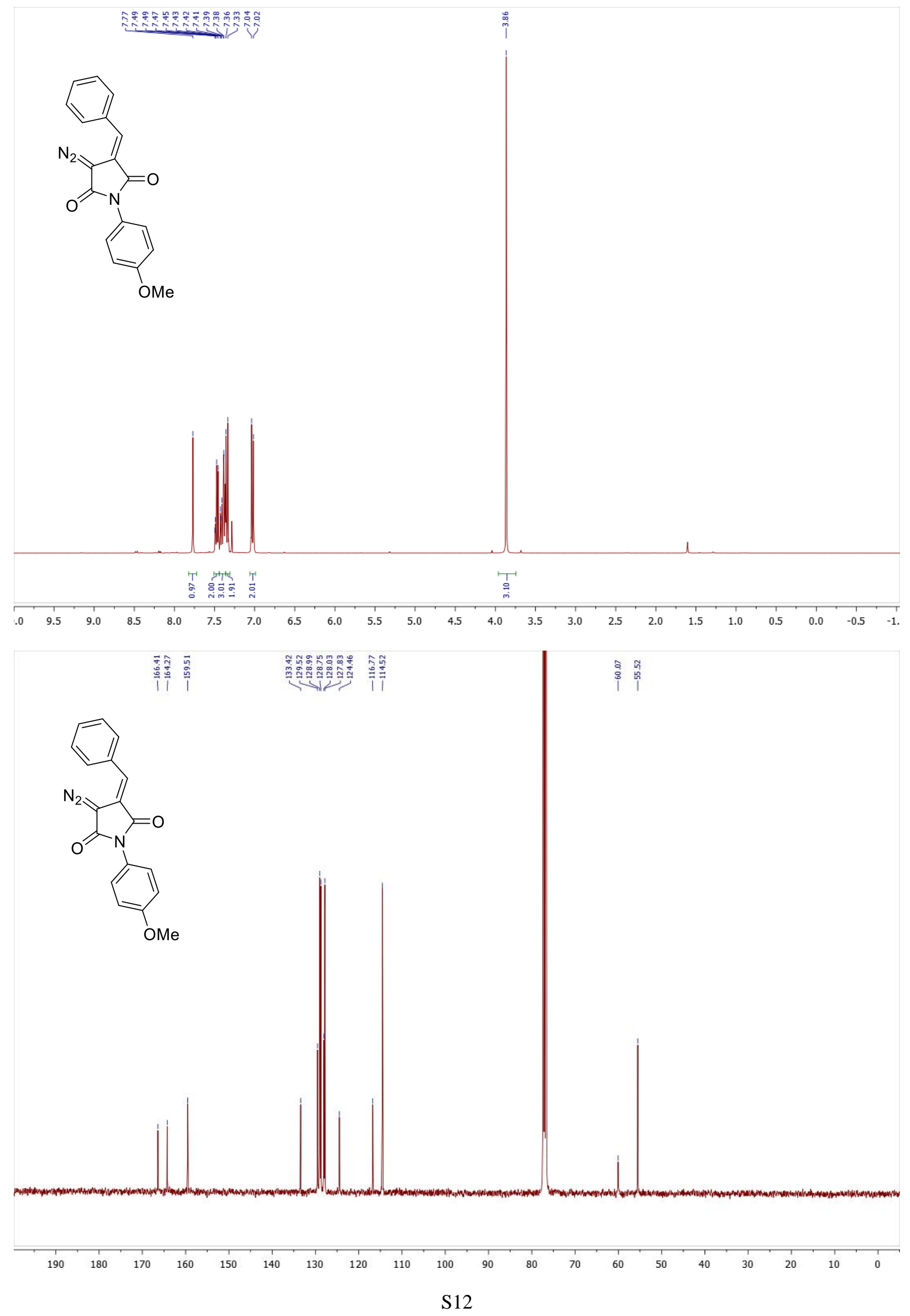


Copies of ${ }^{1} \mathrm{H}\left(400.13 \mathrm{MHz}, \mathrm{CDCl}_{3}\right)$ and ${ }^{13} \mathrm{C}\left(100.61 \mathrm{MHz}, \mathrm{CDCl}_{3}\right)$ spectra of $\mathbf{1 s}$

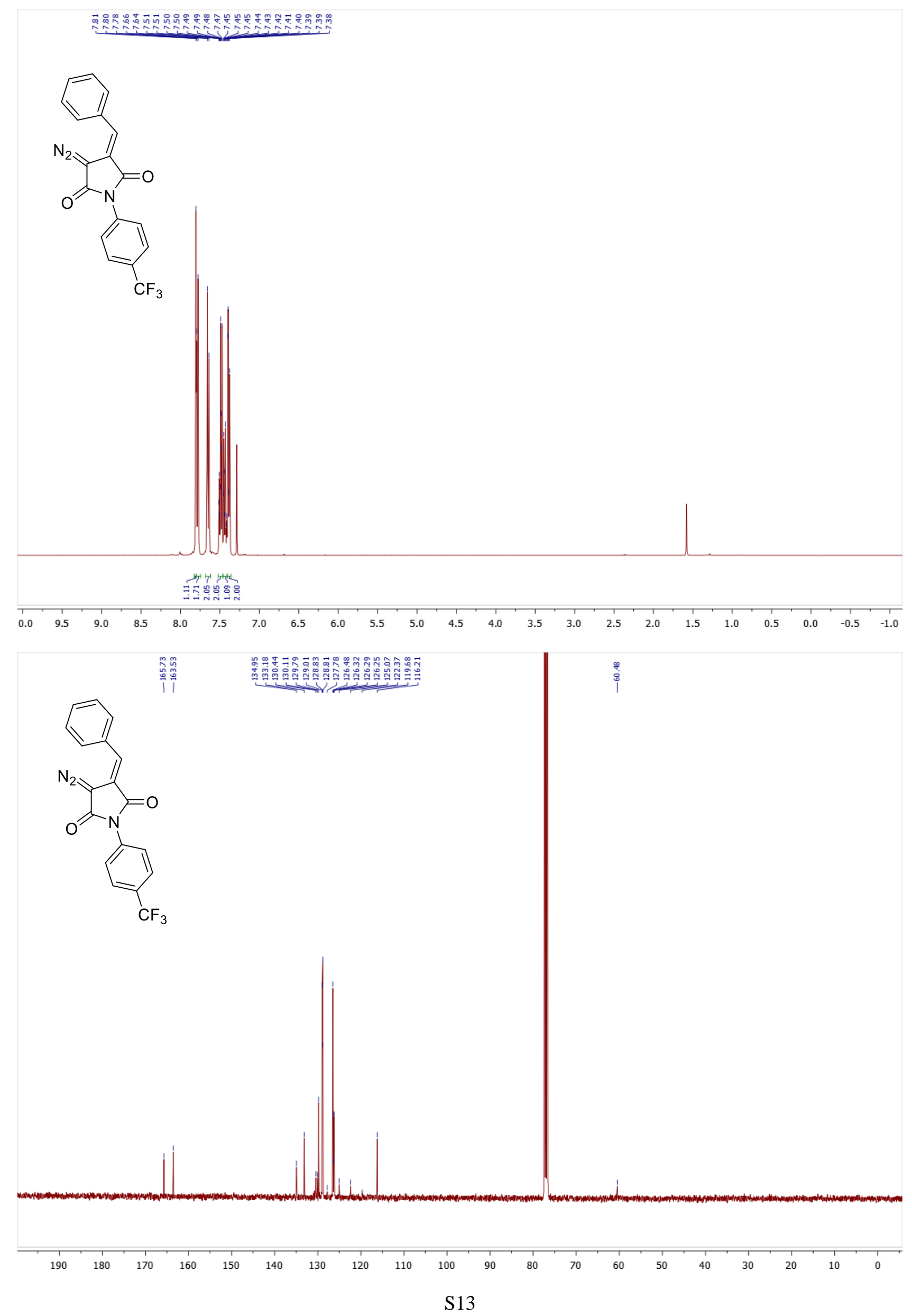


Copy of ${ }^{19} \mathrm{~F}\left(376.50 \mathrm{MHz}, \mathrm{CDCl}_{3}\right)$ spectrum of $\mathbf{1 s}$<smiles></smiles>

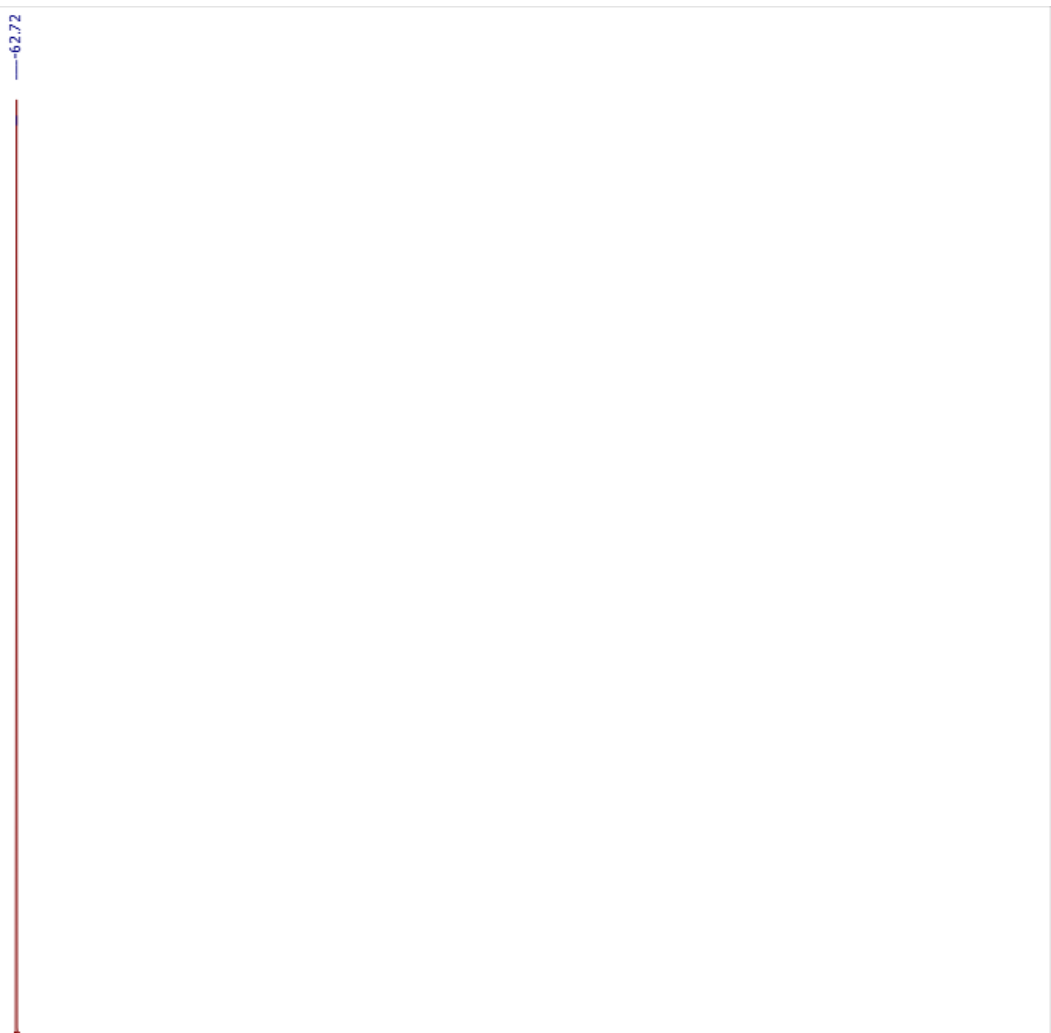

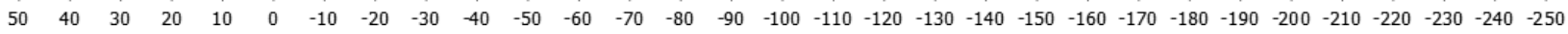


Copies of ${ }^{1} \mathrm{H}\left(400.13 \mathrm{MHz}, \mathrm{CDCl}_{3}\right)$ and ${ }^{13} \mathrm{C}\left(100.61 \mathrm{MHz}, \mathrm{CDCl}_{3}\right)$ spectra of $\mathbf{1 z}$

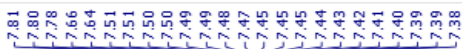
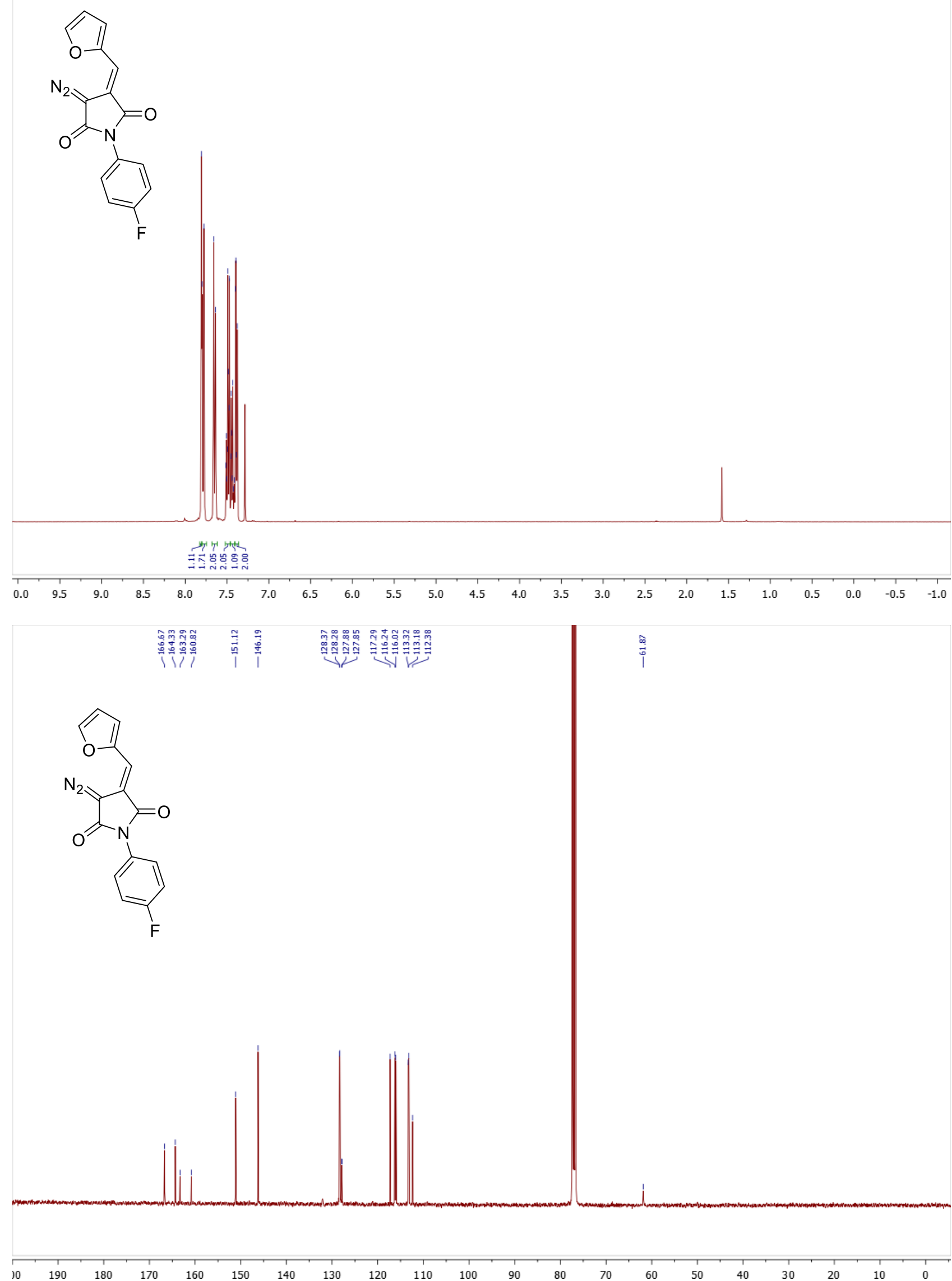
Copy of ${ }^{19} \mathrm{~F}\left(376.50 \mathrm{MHz}, \mathrm{CDCl}_{3}\right)$ spectrum of $\mathbf{1 z}$

$\stackrel{\overrightarrow{\underline{n}}}{\stackrel{i}{i}}$<smiles>N=C1C(=O)N(c2ccc(F)cc2)C(=O)/C1=C/c1ccco1</smiles>

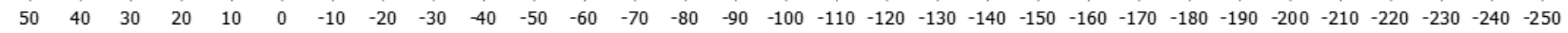


Copies of ${ }^{1} \mathrm{H}\left(400.13 \mathrm{MHz}, \mathrm{CDCl}_{3}\right)$ and ${ }^{13} \mathrm{C}\left(100.61 \mathrm{MHz}, \mathrm{CDCl}_{3}\right)$ spectra of 1aa
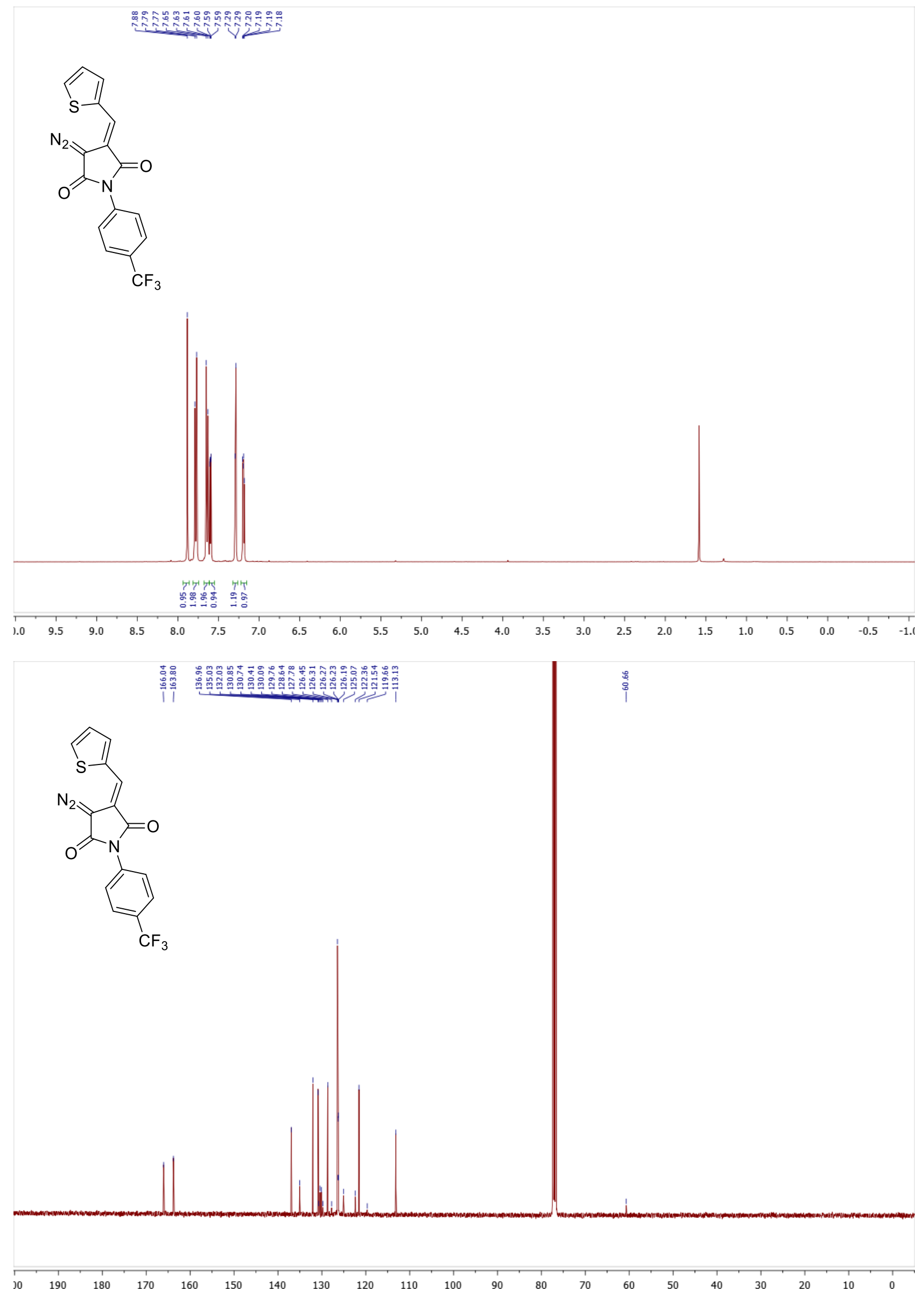
Copy of ${ }^{19} \mathrm{~F}\left(376.50 \mathrm{MHz}, \mathrm{CDCl}_{3}\right)$ spectrum of $\mathbf{1 a a}$

商<smiles>N#CC1C(=O)N(c2ccc(C(F)(F)F)cc2)C(=O)C1=Cc1cccs1</smiles>

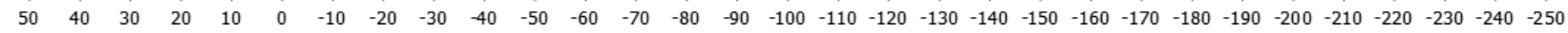


Copies of ${ }^{1} \mathrm{H}\left(400.13 \mathrm{MHz}, \mathrm{CDCl}_{3}\right)$ and ${ }^{13} \mathrm{C}\left(100.61 \mathrm{MHz}, \mathrm{CDCl}_{3}\right)$ spectra of Mab

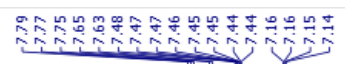
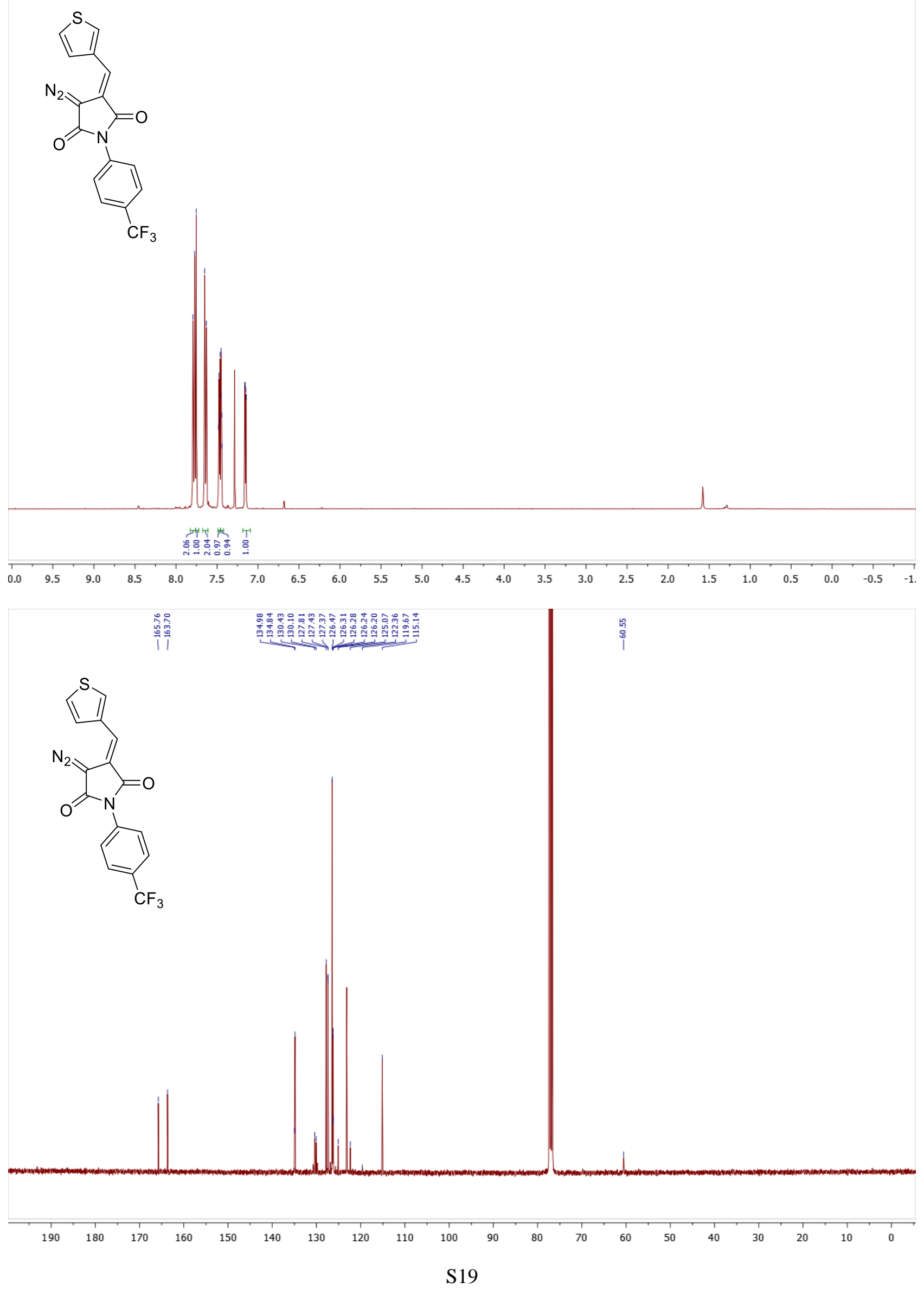
Copy of ${ }^{19} \mathrm{~F}\left(376.50 \mathrm{MHz}, \mathrm{CDCl}_{3}\right)$ spectrum of $\mathbf{1 a b}$

กิ<smiles>N#CC1=C(c2ccsc2)C(=O)N(c2ccc(C(F)(F)F)cc2)C1=O</smiles>

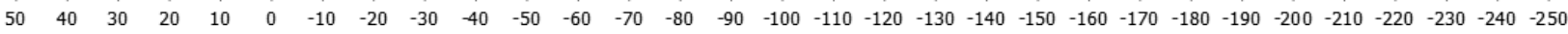


Copies of ${ }^{1} \mathrm{H}\left(400.13 \mathrm{MHz}, \mathrm{CDCl}_{3}\right)$ and ${ }^{13} \mathrm{C}\left(100.61 \mathrm{MHz}, \mathrm{CDCl}_{3}\right)$ spectra of $\mathbf{1 a c}$
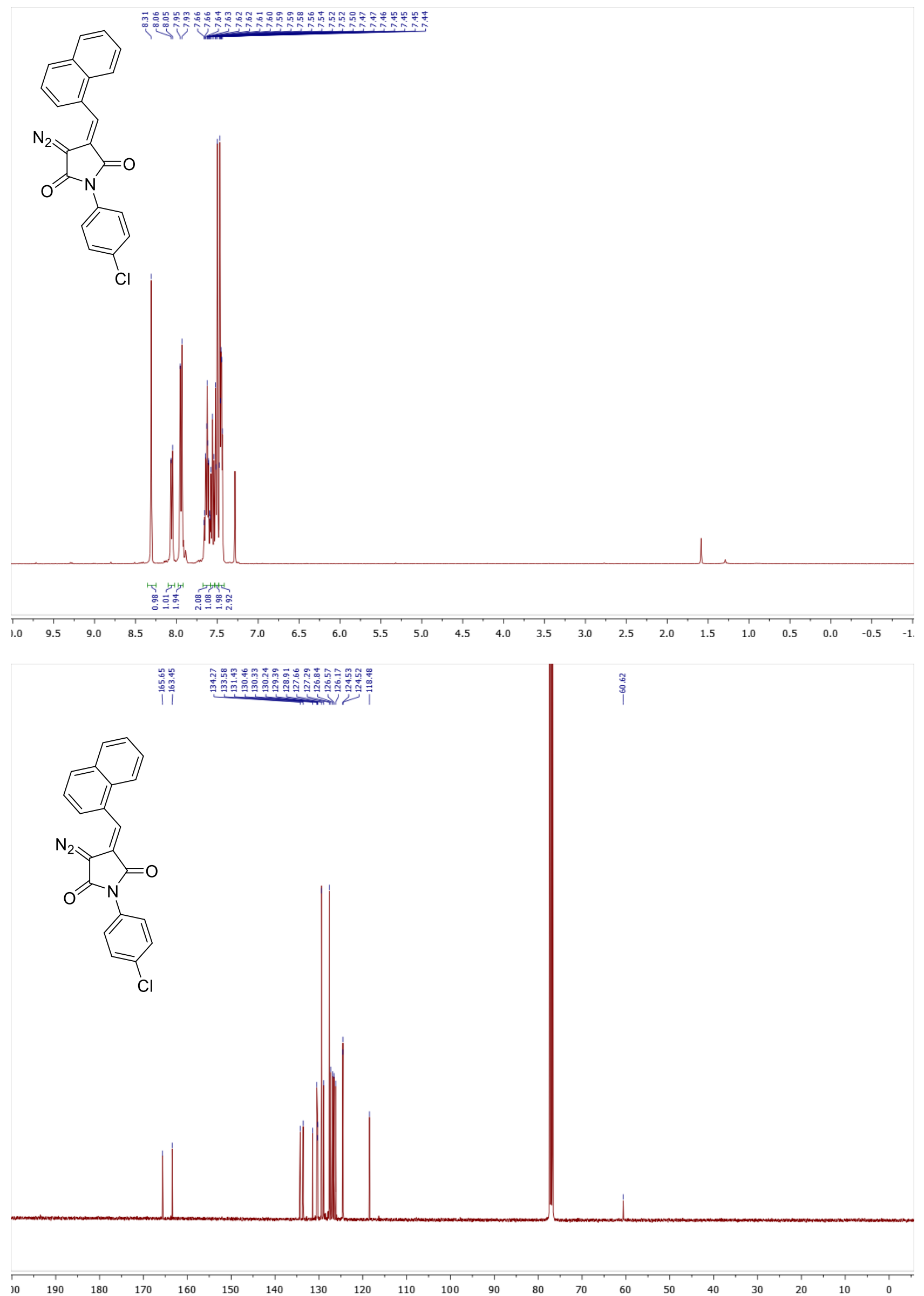
Copies of ${ }^{1} \mathrm{H}\left(400.13 \mathrm{MHz}, \mathrm{CDCl}_{3}\right)$ and ${ }^{13} \mathrm{C}\left(100.61 \mathrm{MHz}, \mathrm{CDCl}_{3}\right)$ spectra of $\mathbf{1 a d}$

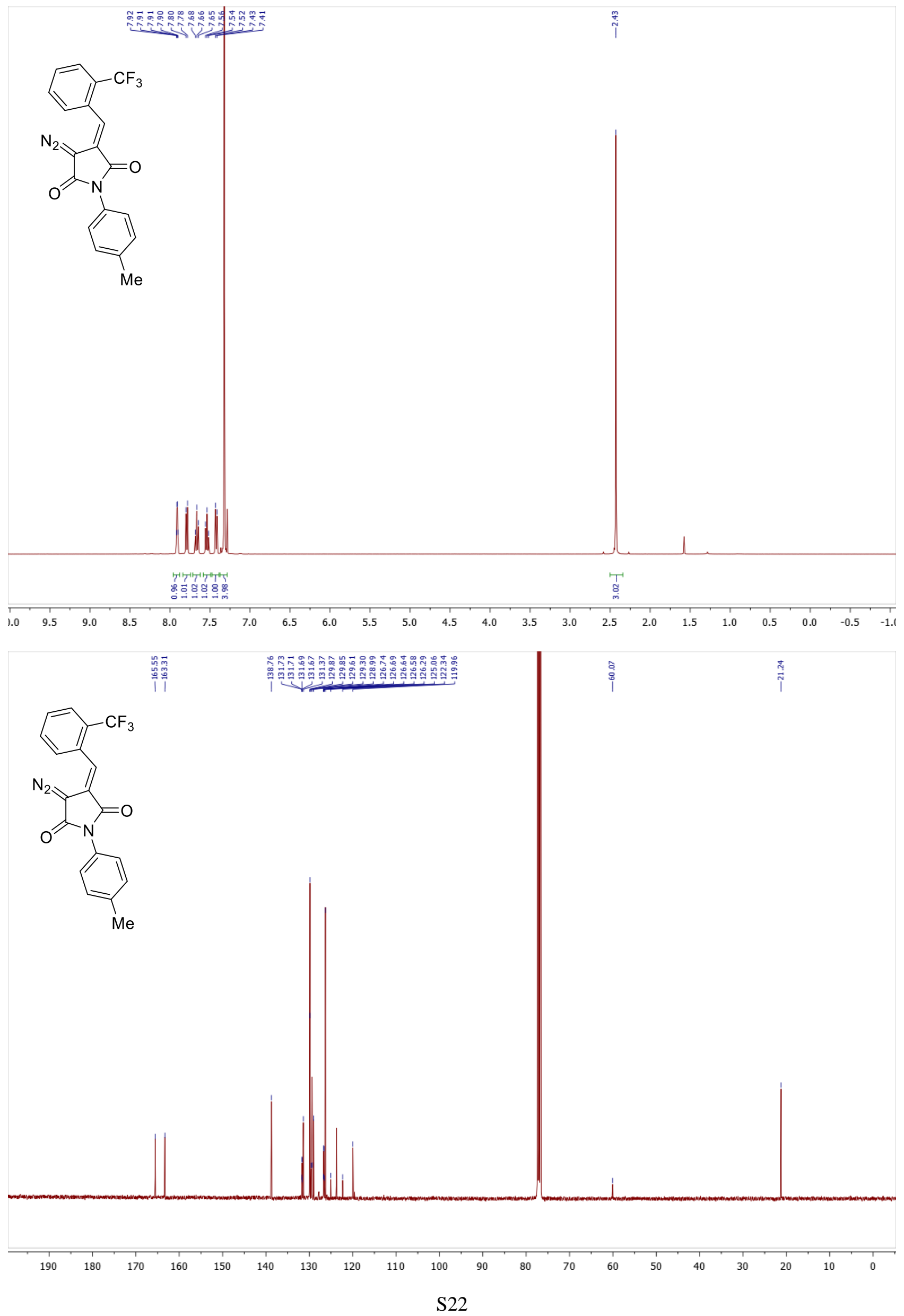


Copy of ${ }^{19} \mathrm{~F}\left(376.50 \mathrm{MHz}, \mathrm{CDCl}_{3}\right)$ spectrum of $\mathbf{1 a d}$

i<smiles>N=C1C(=O)N(c2ccc([N+](=O)[O-])cc2)C(=O)/C1=C/c1ccccc1C(F)(F)F</smiles>

$\begin{array}{lllllllllllllllllllllllllllllll}50 & 40 & 30 & 20 & 10 & 0 & -10 & -20 & -30 & -40 & -50 & -60 & -70 & -80 & -90 & -100 & -110 & -120 & -130 & -140 & -150 & -160 & -170 & -180 & -190 & -200 & -210 & -220 & -230 & -240 & -250\end{array}$ 
Copies of ${ }^{1} \mathrm{H}\left(400.13 \mathrm{MHz}, \mathrm{CDCl}_{3}\right)$ and ${ }^{13} \mathrm{C}\left(100.61 \mathrm{MHz}, \mathrm{CDCl}_{3}\right)$ spectra of $\mathbf{2 a}$

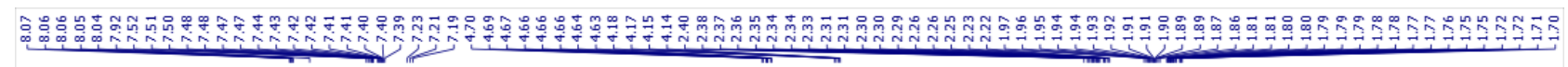
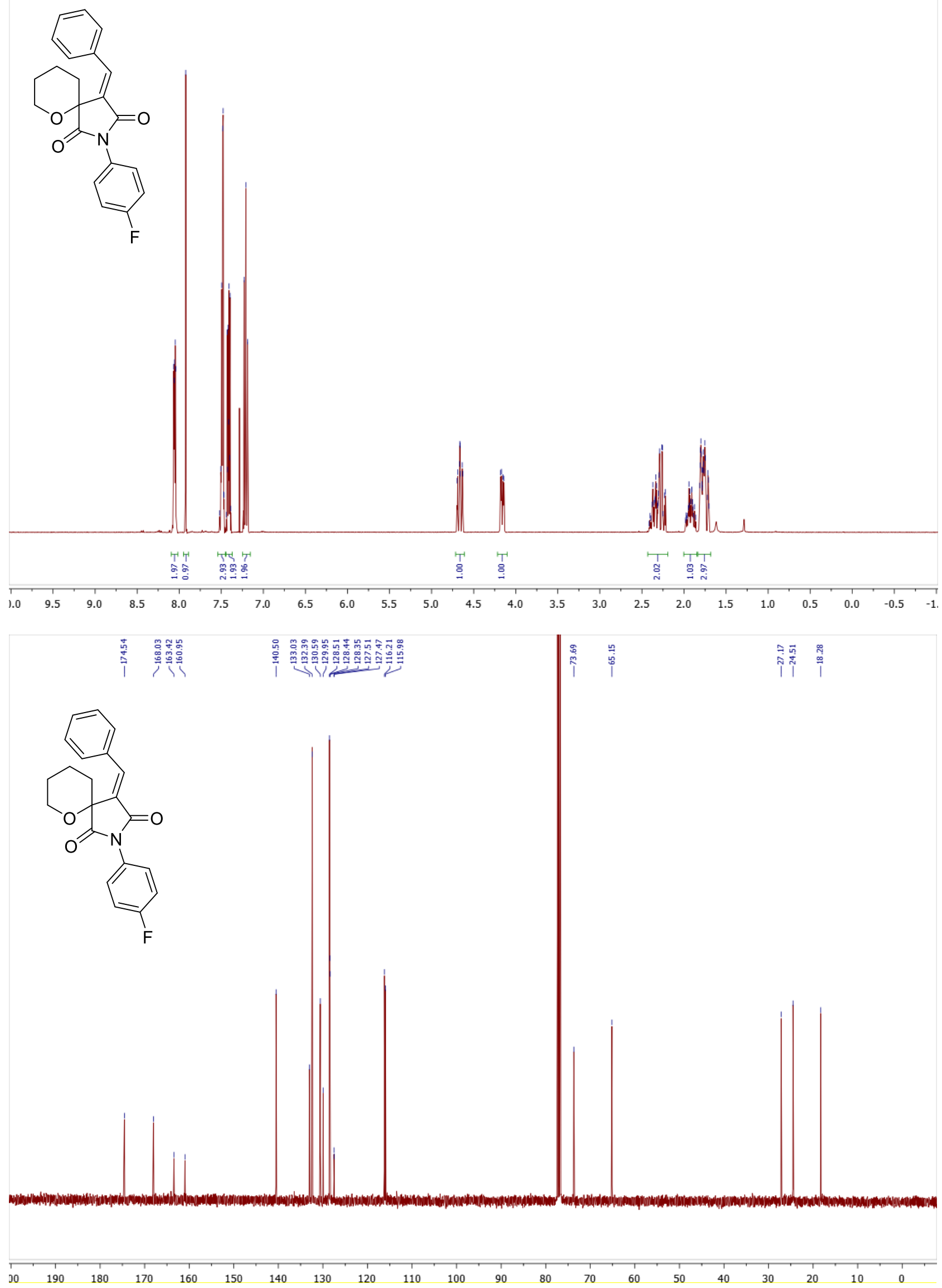
Copy of ${ }^{19} \mathrm{~F}\left(376.50 \mathrm{MHz}, \mathrm{CDCl}_{3}\right)$ spectrum of $\mathbf{2 a}$<smiles>O=C1/C(=C/c2ccccc2)C2(CCCCO2)C(=O)N1c1ccc(F)cc1</smiles>

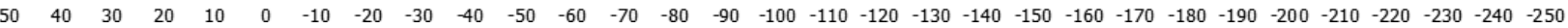


Copies of ${ }^{1} \mathrm{H}\left(400.13 \mathrm{MHz}, \mathrm{CDCl}_{3}\right)$ and ${ }^{13} \mathrm{C}\left(100.61 \mathrm{MHz}, \mathrm{CDCl}_{3}\right)$ spectra of $(\boldsymbol{R} / \boldsymbol{S}, \boldsymbol{S} / \boldsymbol{R})-\mathbf{6} \mathbf{a}^{\mathbf{m i n}}$

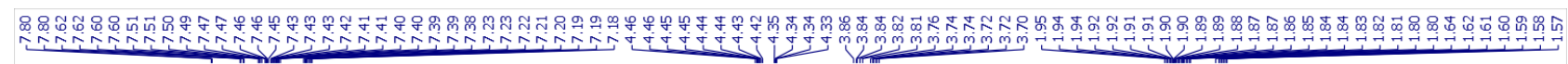
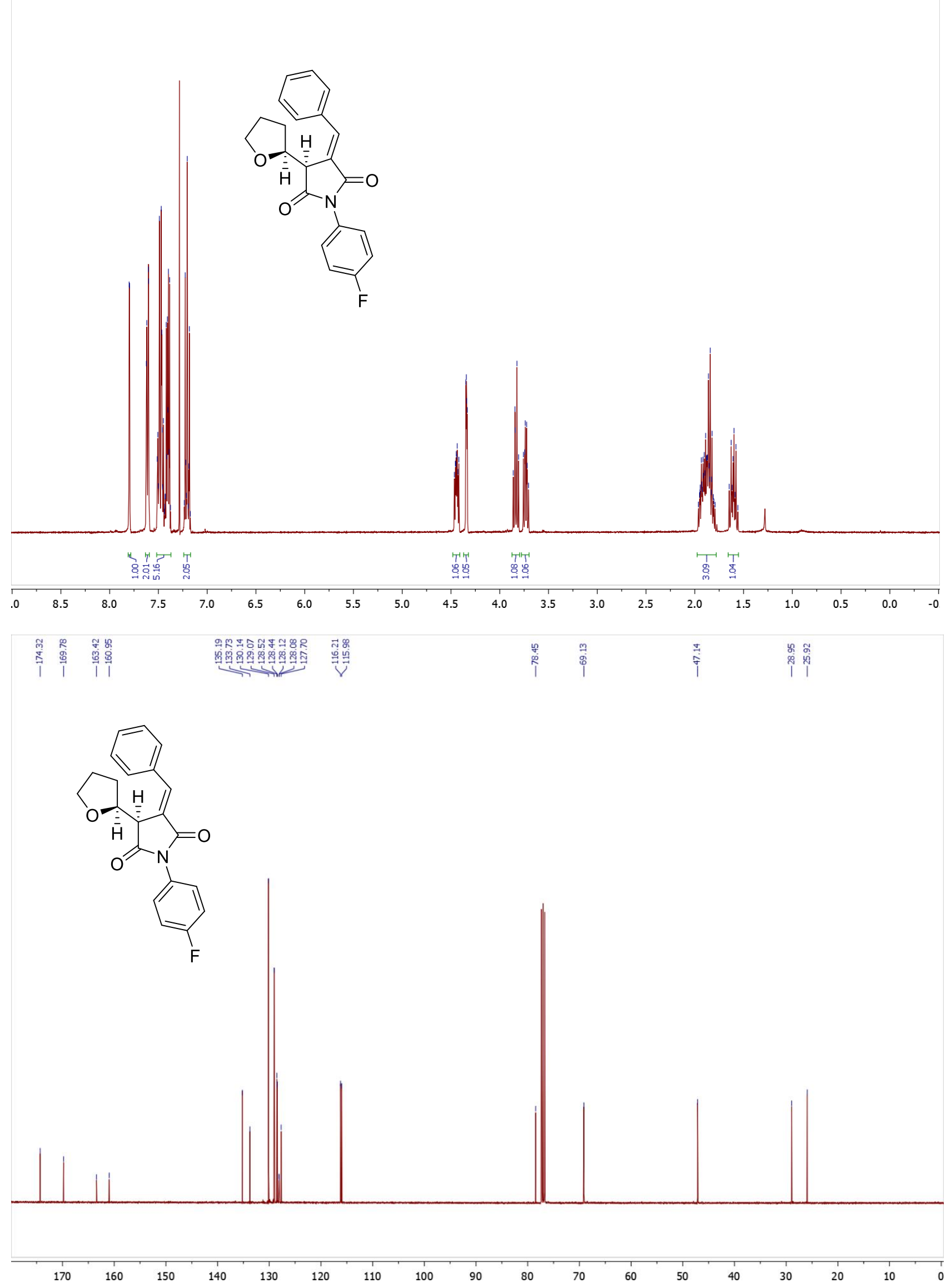
Copy of ${ }^{19} \mathrm{~F}\left(376.50 \mathrm{MHz}, \mathrm{CDCl}_{3}\right)$ spectrum of $(\boldsymbol{R} / \mathbf{S}, \mathbf{S} / \boldsymbol{R})-\mathbf{6} \mathbf{a}^{\mathbf{m i n}}$

$\stackrel{\stackrel{0}{*}}{\stackrel{i}{i}}$<smiles>O=C1C2=Cc3ccccc3[C@H]2[C@H]2OCCO[C@H]12</smiles>

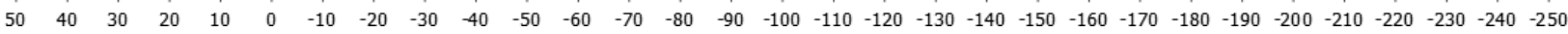


Copies of ${ }^{1} \mathrm{H}\left(400.13 \mathrm{MHz}, \mathrm{CDCl}_{3}\right)$ and ${ }^{13} \mathrm{C}\left(100.61 \mathrm{MHz}, \mathrm{CDCl}_{3}\right)$ spectra of $(\mathbf{S} / \boldsymbol{R}, \mathbf{S} / \mathbf{R})-\mathbf{6 a}{ }^{\text {maj }}$

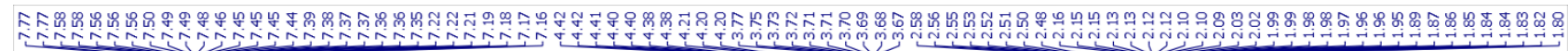
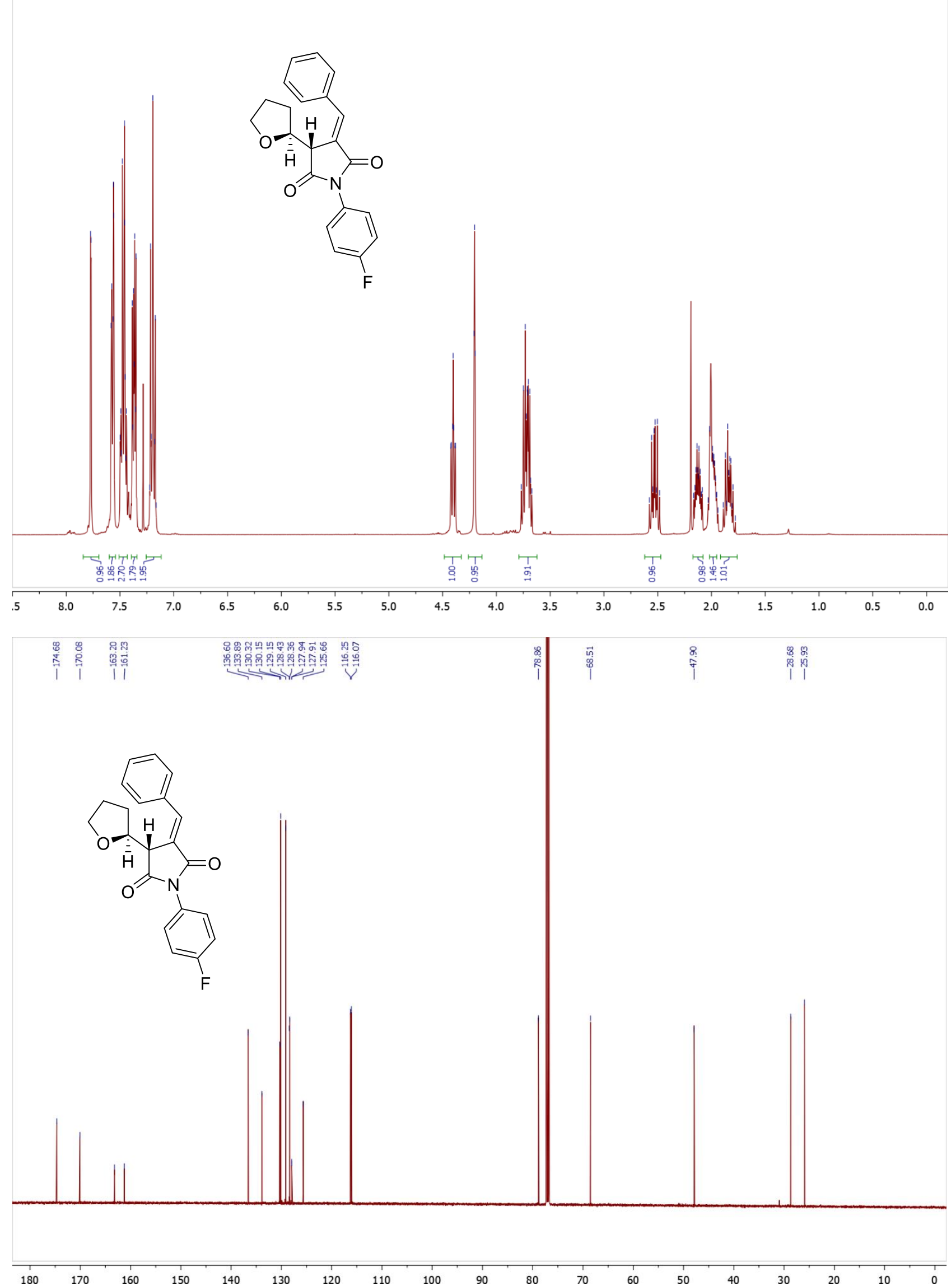
Copy of ${ }^{19} \mathrm{~F}\left(376.50 \mathrm{MHz}, \mathrm{CDCl}_{3}\right)$ spectrum of $(\boldsymbol{S} / \boldsymbol{R}, \mathbf{S} / \boldsymbol{R})-\mathbf{6} \mathbf{a}^{\text {maj }}$

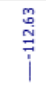<smiles>O=C1C2=Cc3ccccc3[C@H]2C(=O)N1c1ccc(F)cc1</smiles>

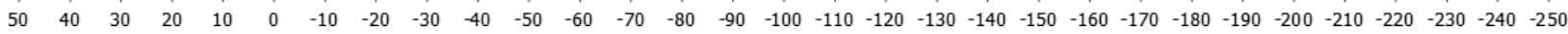


Copies of ${ }^{1} \mathrm{H}\left(400.13 \mathrm{MHz}, \mathrm{CDCl}_{3}\right)$ and ${ }^{13} \mathrm{C}\left(100.61 \mathrm{MHz}, \mathrm{CDCl}_{3}\right)$ spectra of $\mathbf{2 b}$

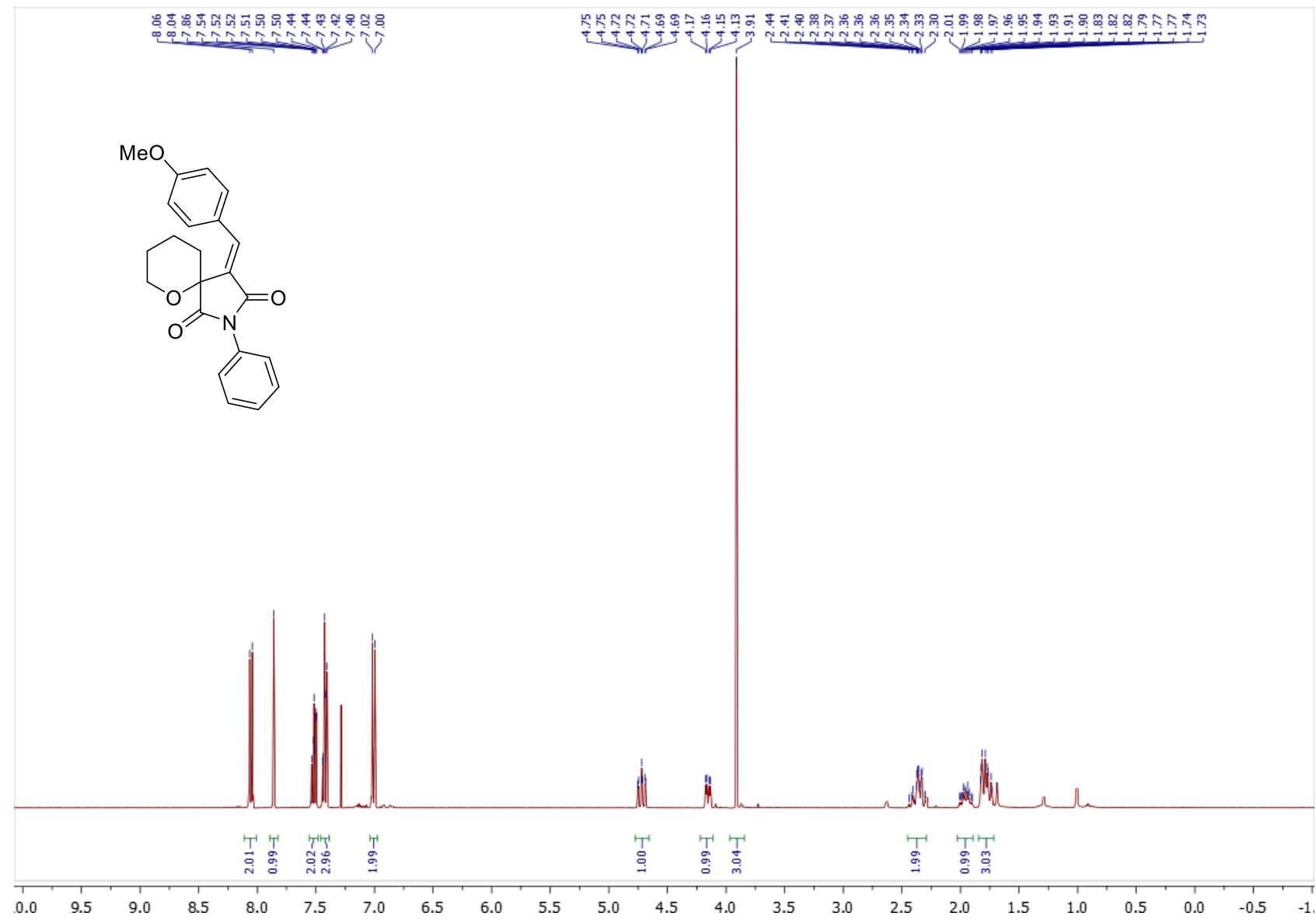

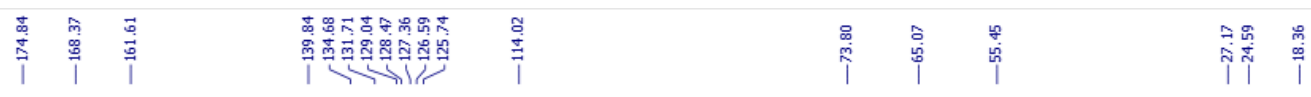

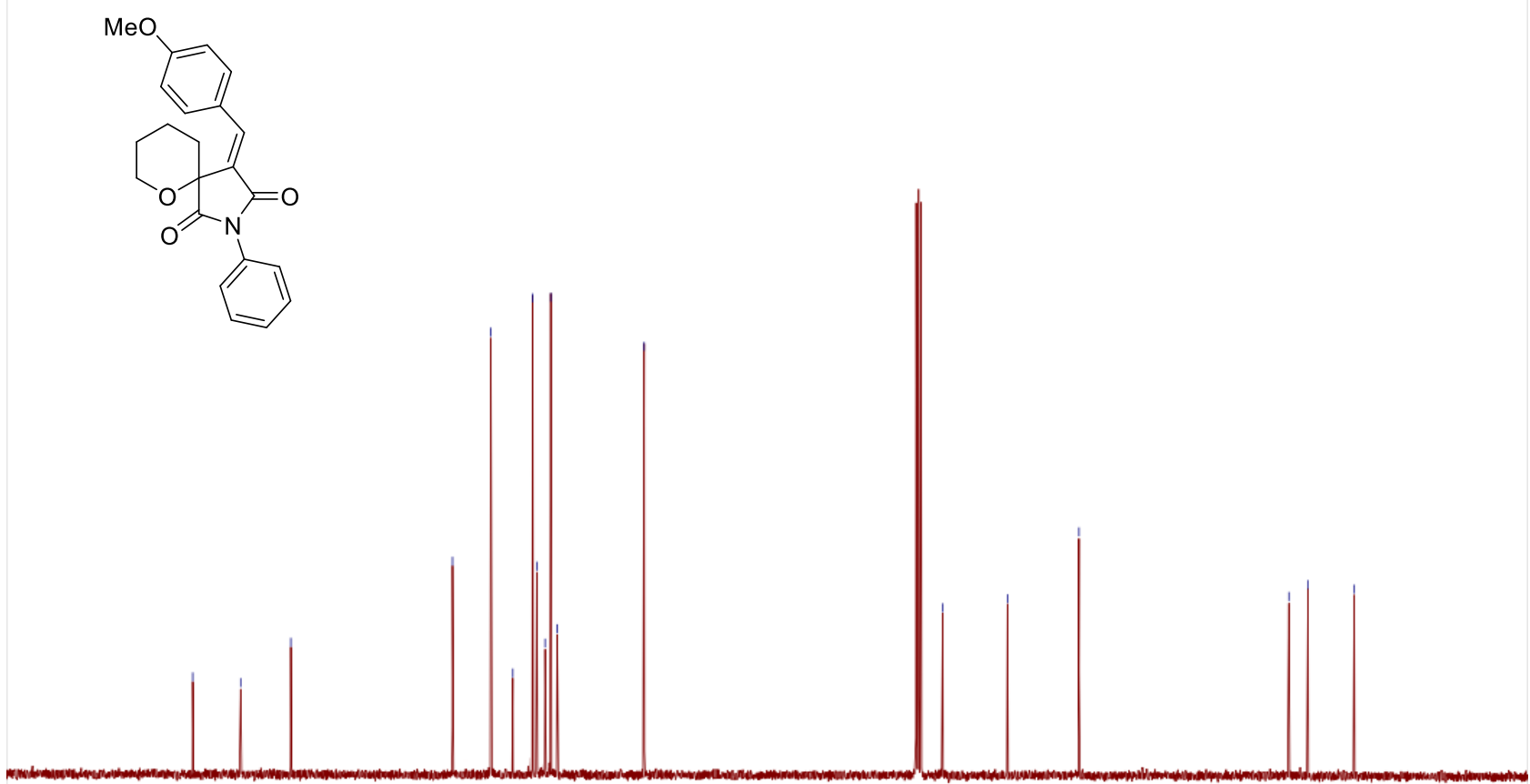

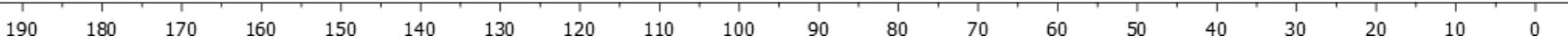


Copies of ${ }^{1} \mathrm{H}\left(400.13 \mathrm{MHz}, \mathrm{CDCl}_{3}\right)$ and ${ }^{13} \mathrm{C}\left(100.61 \mathrm{MHz}, \mathrm{CDCl}_{3}\right)$ spectra of $(\boldsymbol{R} / \mathbf{S}, \mathbf{S} / \boldsymbol{R})-\mathbf{6} \mathbf{b}^{\min }$
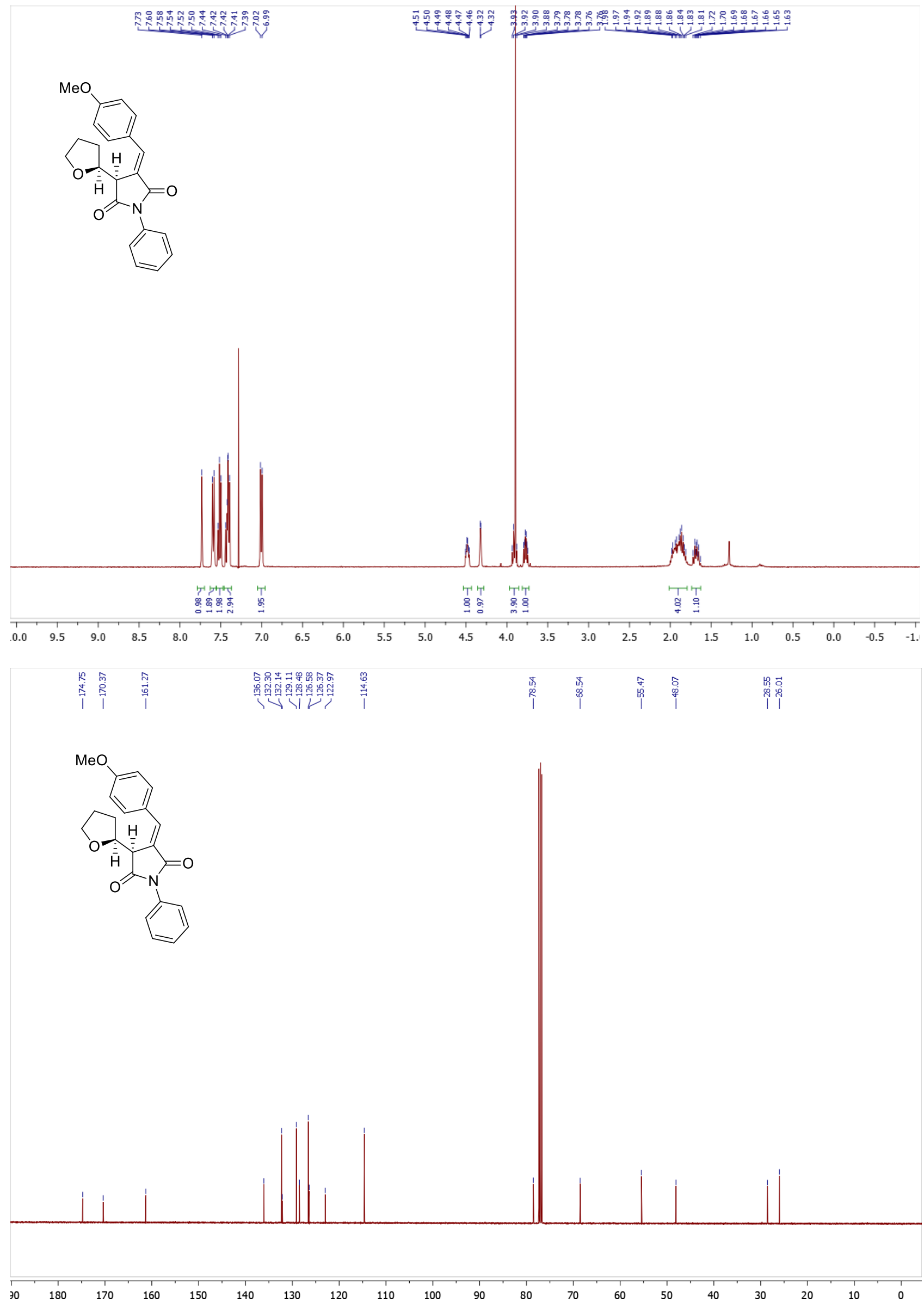
Copies of ${ }^{1} \mathrm{H}\left(400.13 \mathrm{MHz}, \mathrm{CDCl}_{3}\right)$ and ${ }^{13} \mathrm{C}\left(100.61 \mathrm{MHz}, \mathrm{CDCl}_{3}\right)$ spectra of $(\boldsymbol{S} / \boldsymbol{R}, \mathbf{S} / \boldsymbol{R})-\mathbf{6} \mathbf{b}^{\text {maj }}$

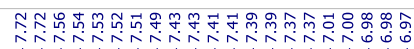

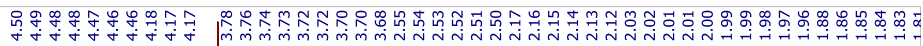
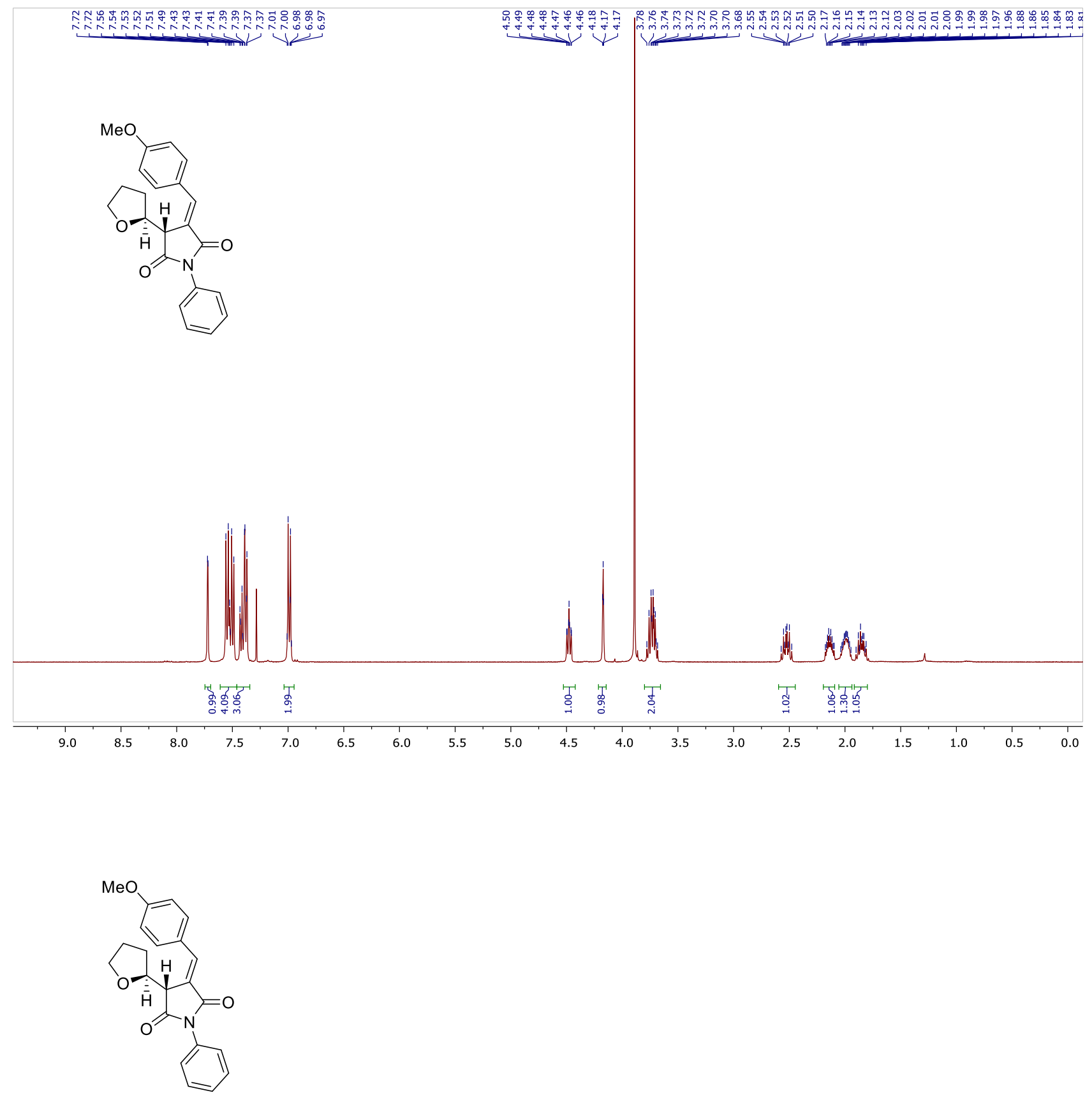


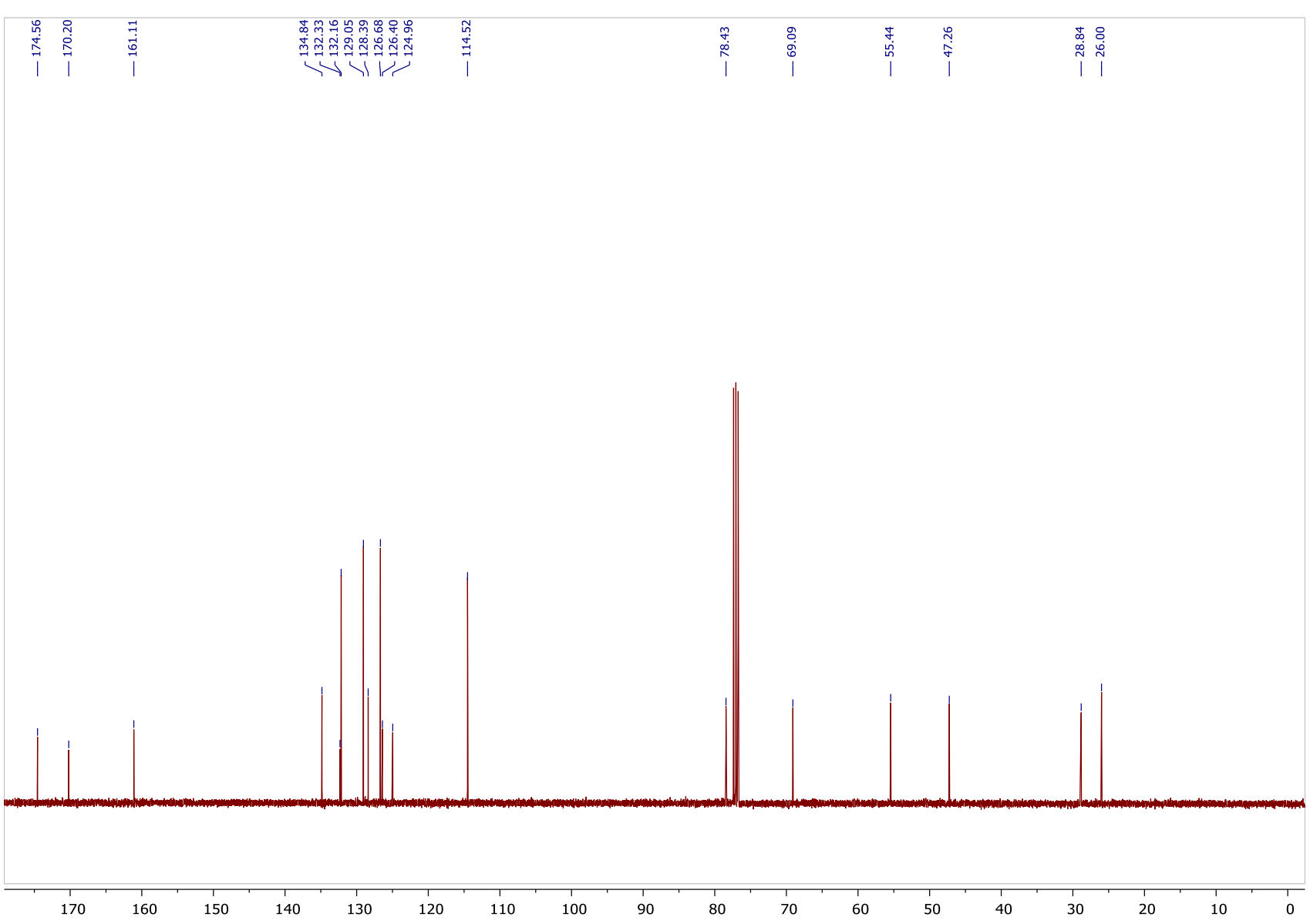

Copies of ${ }^{1} \mathrm{H}\left(400.13 \mathrm{MHz}, \mathrm{CDCl}_{3}\right)$ and ${ }^{13} \mathrm{C}\left(100.61 \mathrm{MHz}, \mathrm{CDCl}_{3}\right)$ spectra of $\mathbf{2 c}$

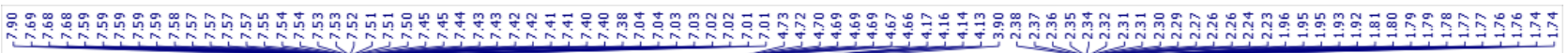
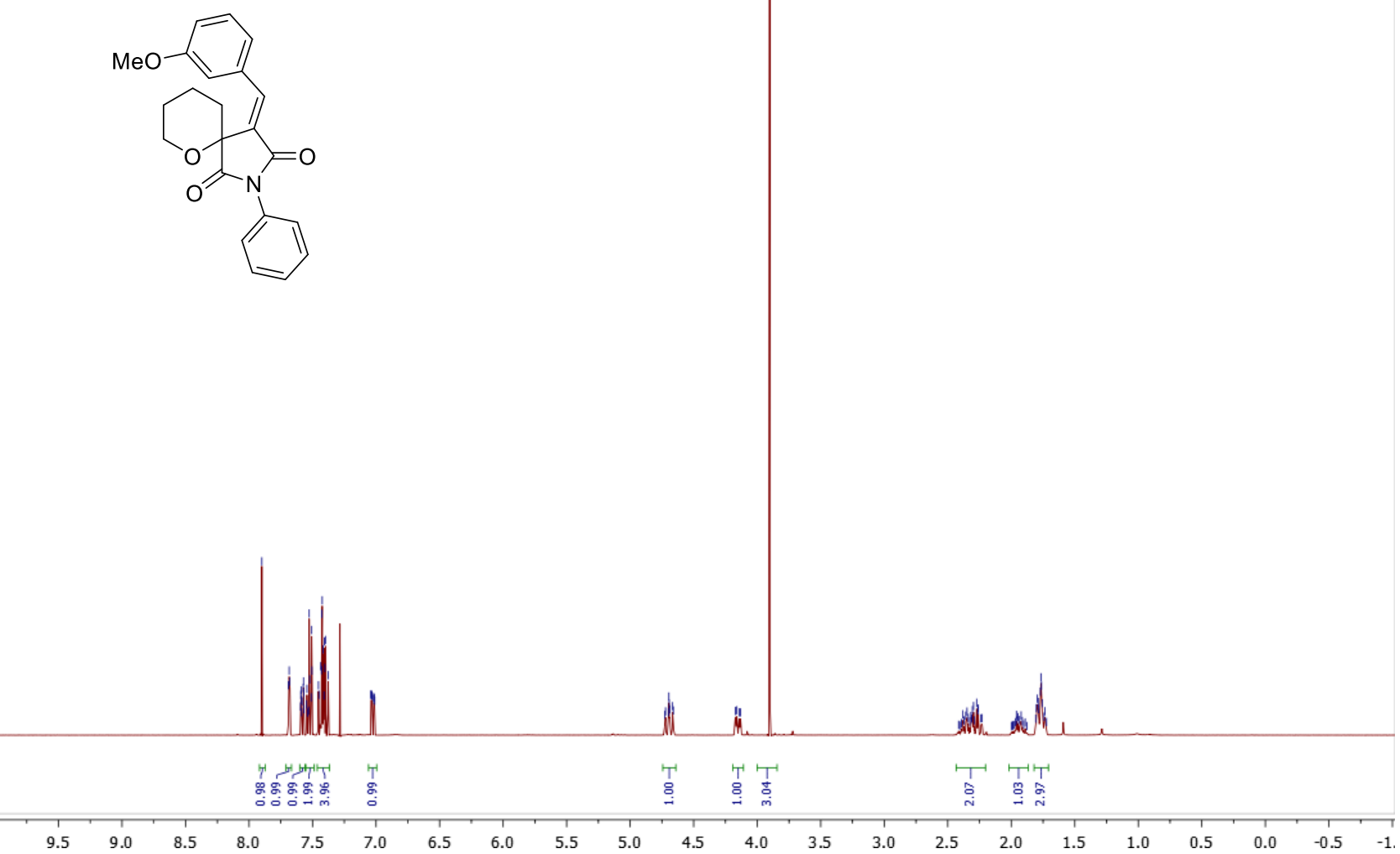

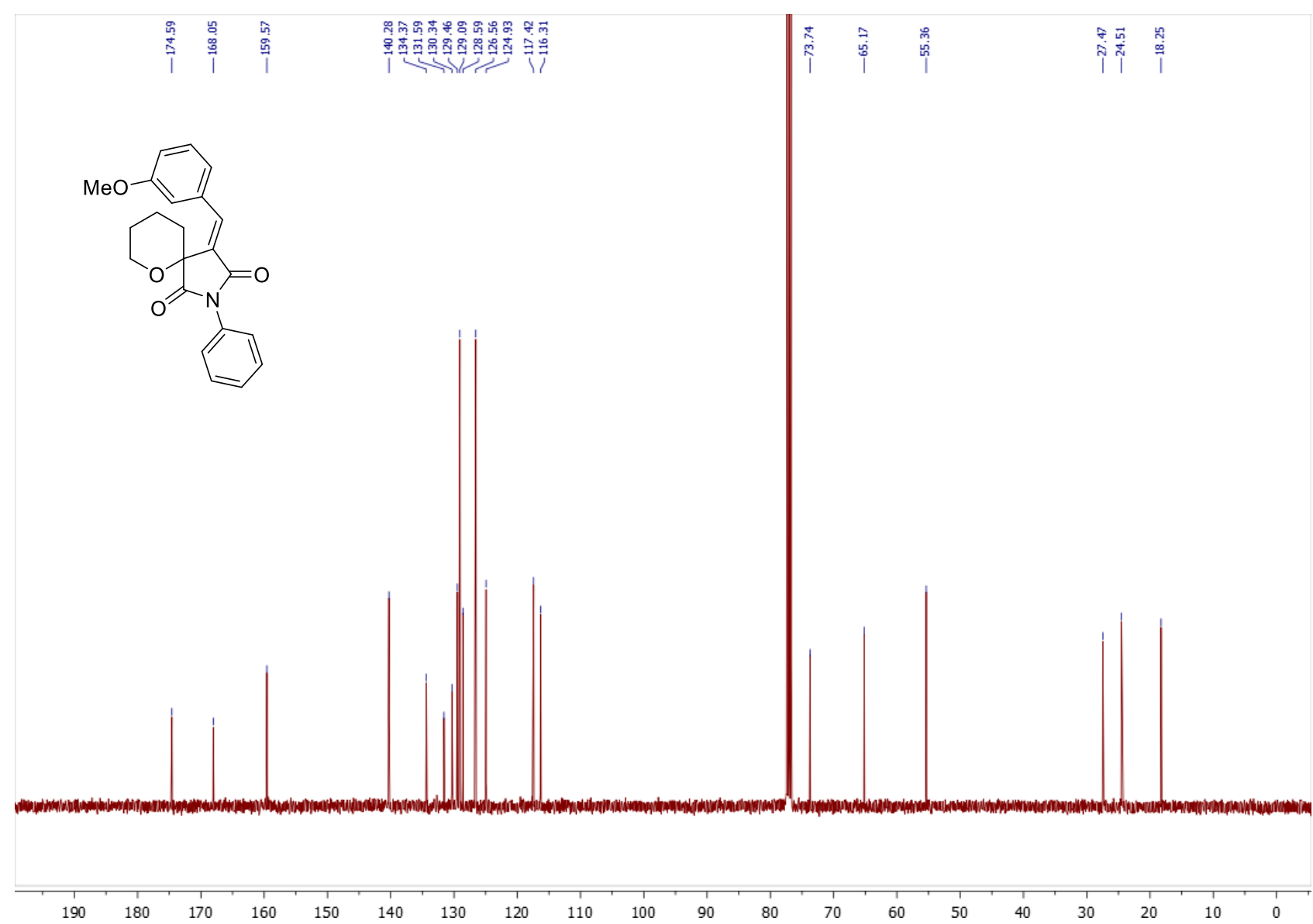

Copies of ${ }^{1} \mathrm{H}\left(400.13 \mathrm{MHz}, \mathrm{CDCl}_{3}\right)$ and ${ }^{13} \mathrm{C}\left(100.61 \mathrm{MHz}, \mathrm{CDCl}_{3}\right)$ spectra of $\mathbf{2 d}$

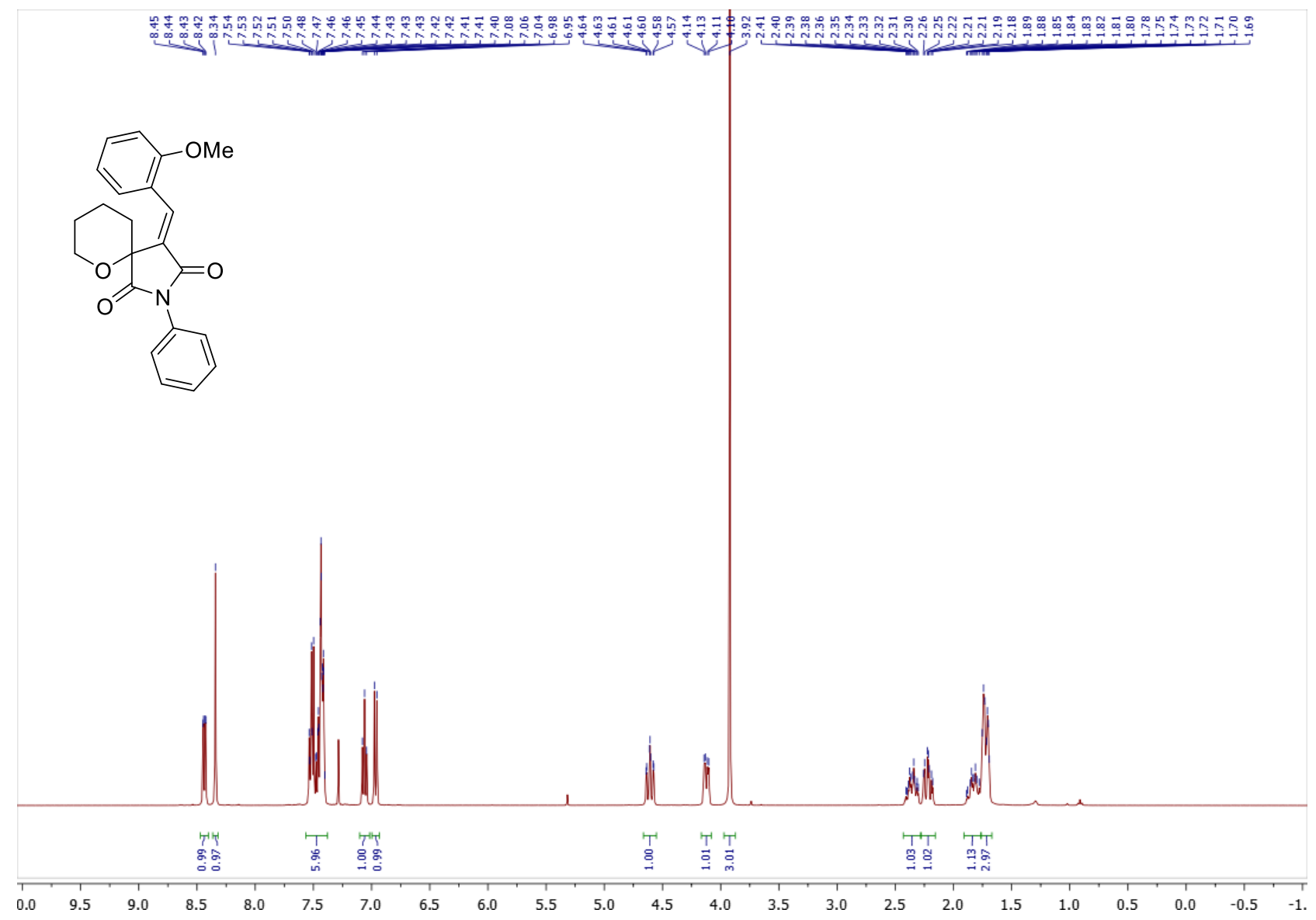




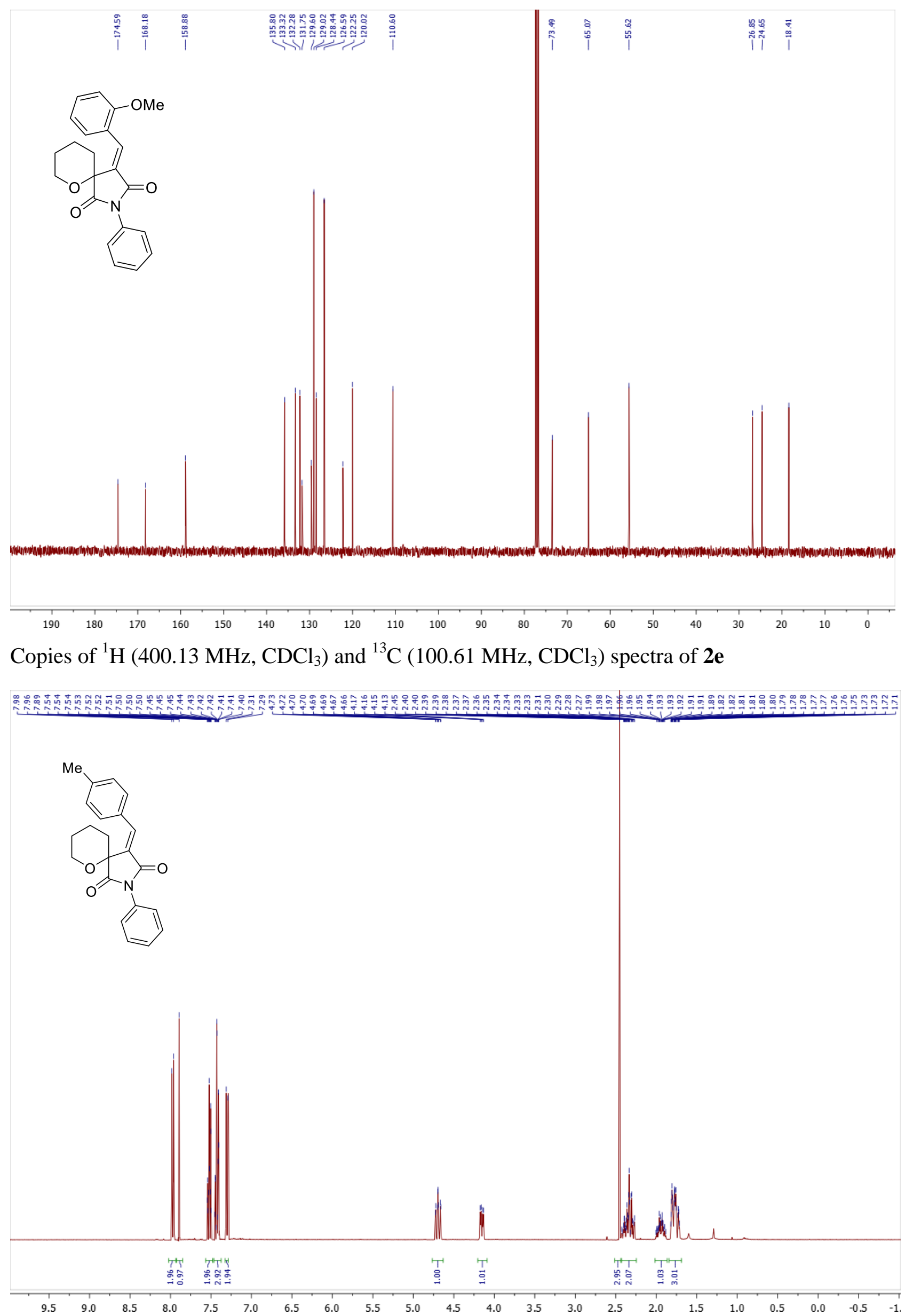



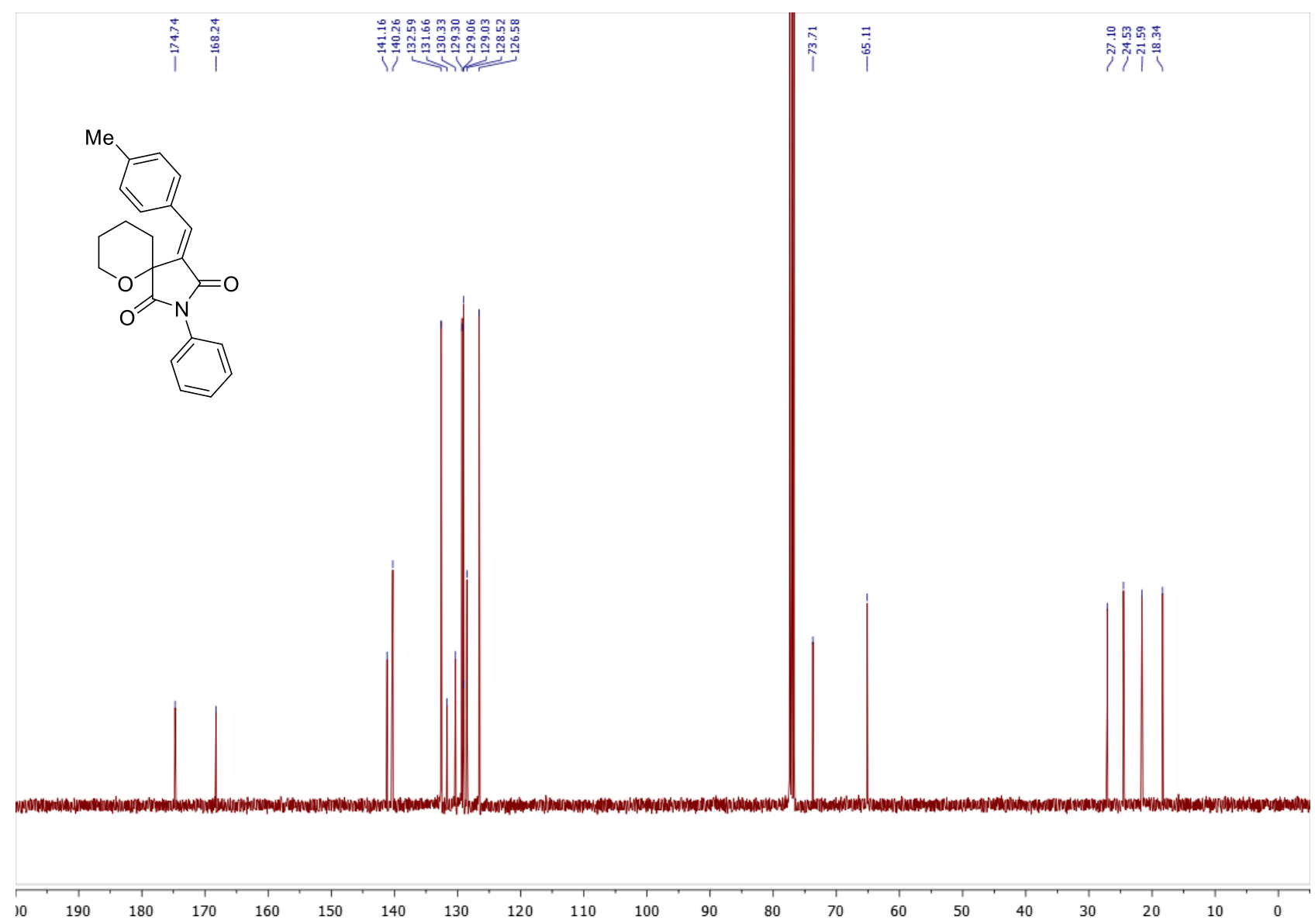

Copies of ${ }^{1} \mathrm{H}\left(400.13 \mathrm{MHz}, \mathrm{CDCl}_{3}\right)$ and ${ }^{13} \mathrm{C}\left(100.61 \mathrm{MHz}, \mathrm{CDCl}_{3}\right)$ spectra of $\mathbf{2 f}$

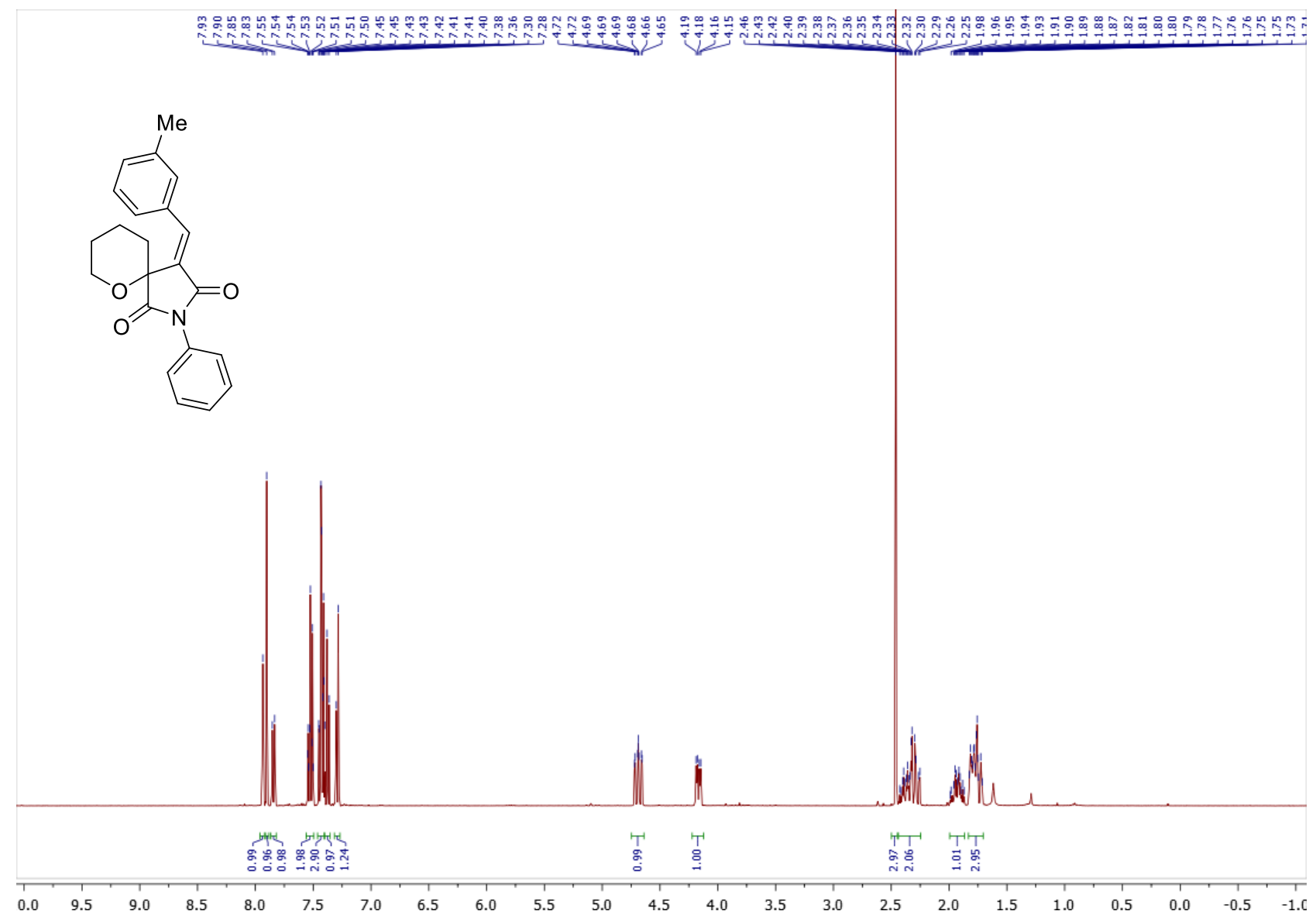




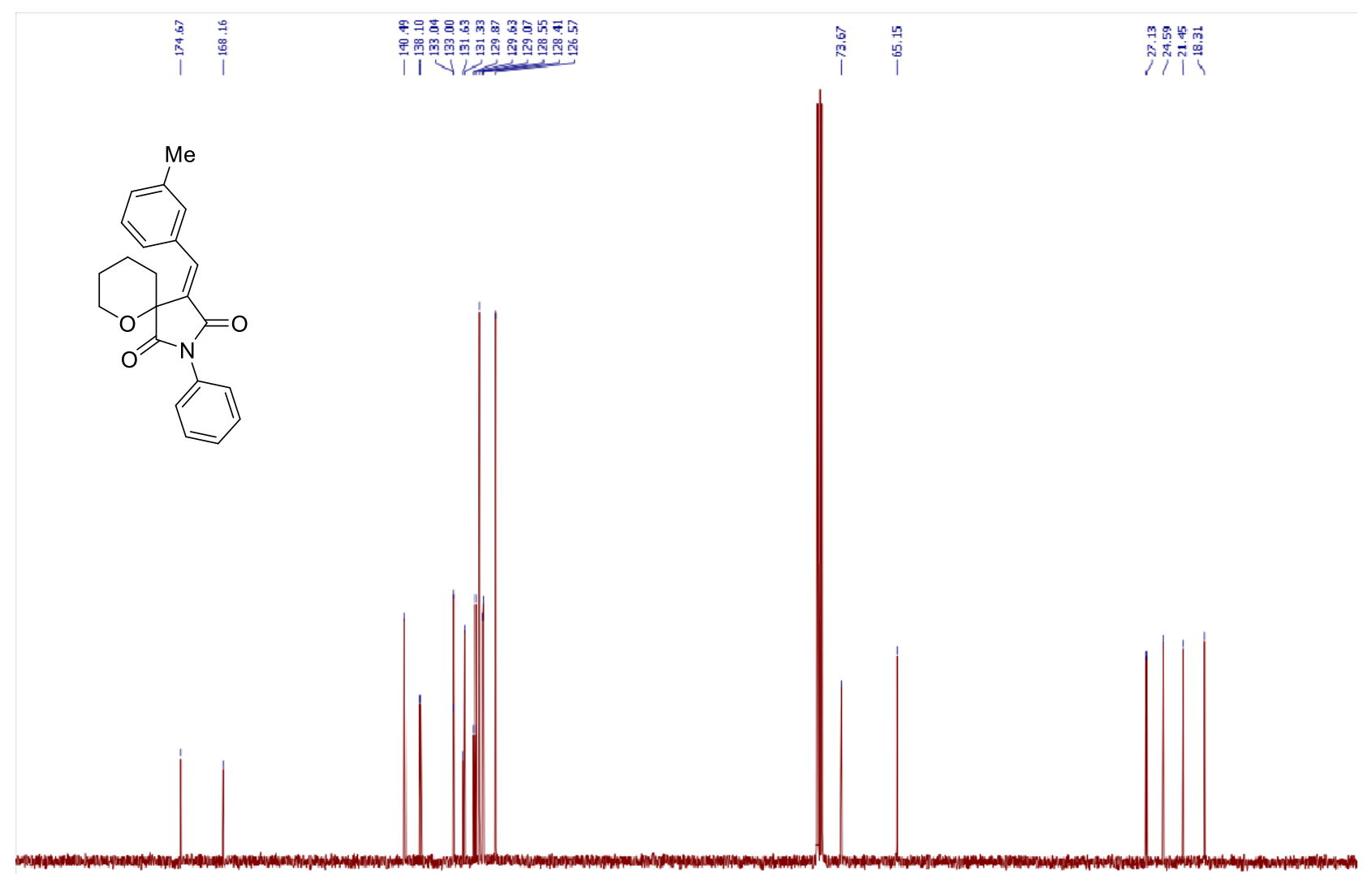

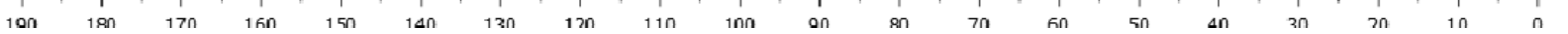

Copies of ${ }^{1} \mathrm{H}\left(400.13 \mathrm{MHz}, \mathrm{CDCl}_{3}\right)$ and ${ }^{13} \mathrm{C}\left(100.61 \mathrm{MHz}, \mathrm{CDCl}_{3}\right)$ spectra of $\mathbf{2 g}$

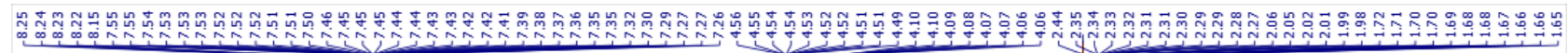

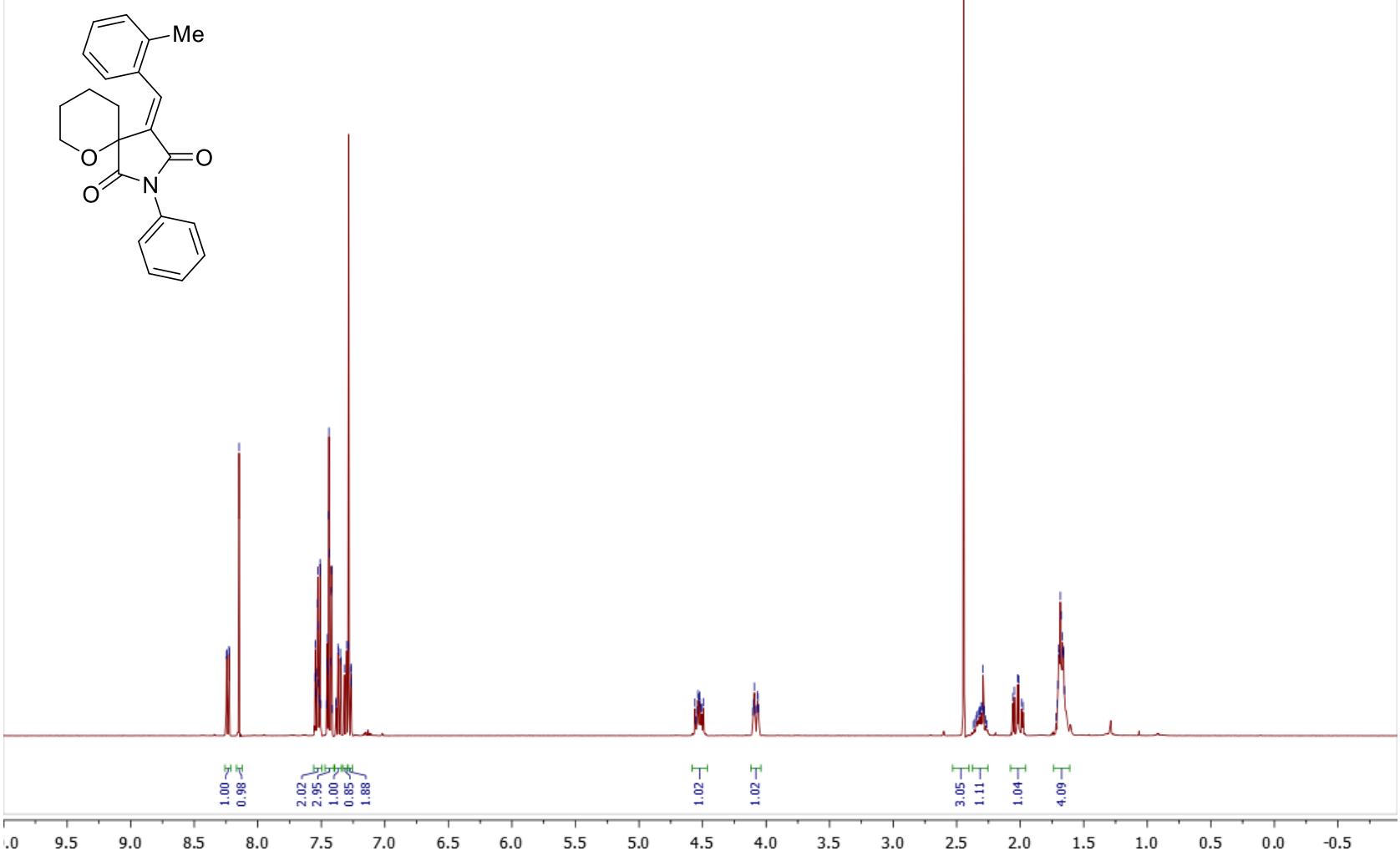



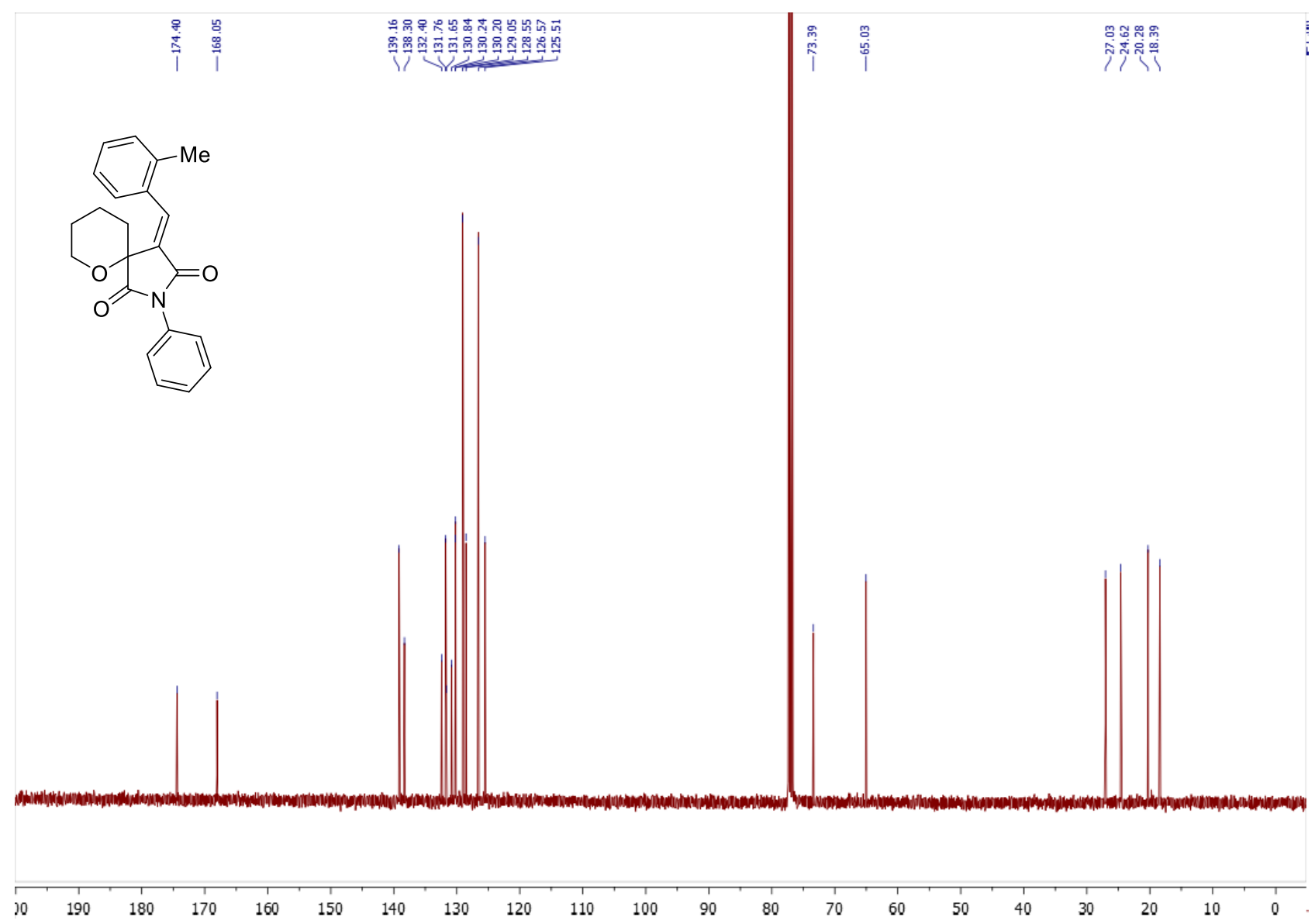

Copies of ${ }^{1} \mathrm{H}\left(400.13 \mathrm{MHz}, \mathrm{CDCl}_{3}\right)$ and ${ }^{13} \mathrm{C}\left(100.61 \mathrm{MHz}, \mathrm{CDCl}_{3}\right)$ spectra of $\mathbf{2 h}$

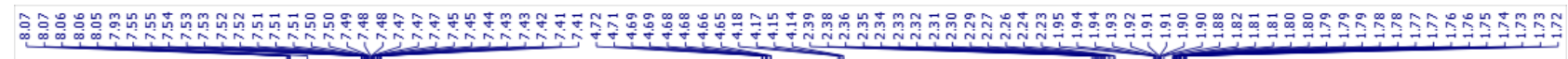

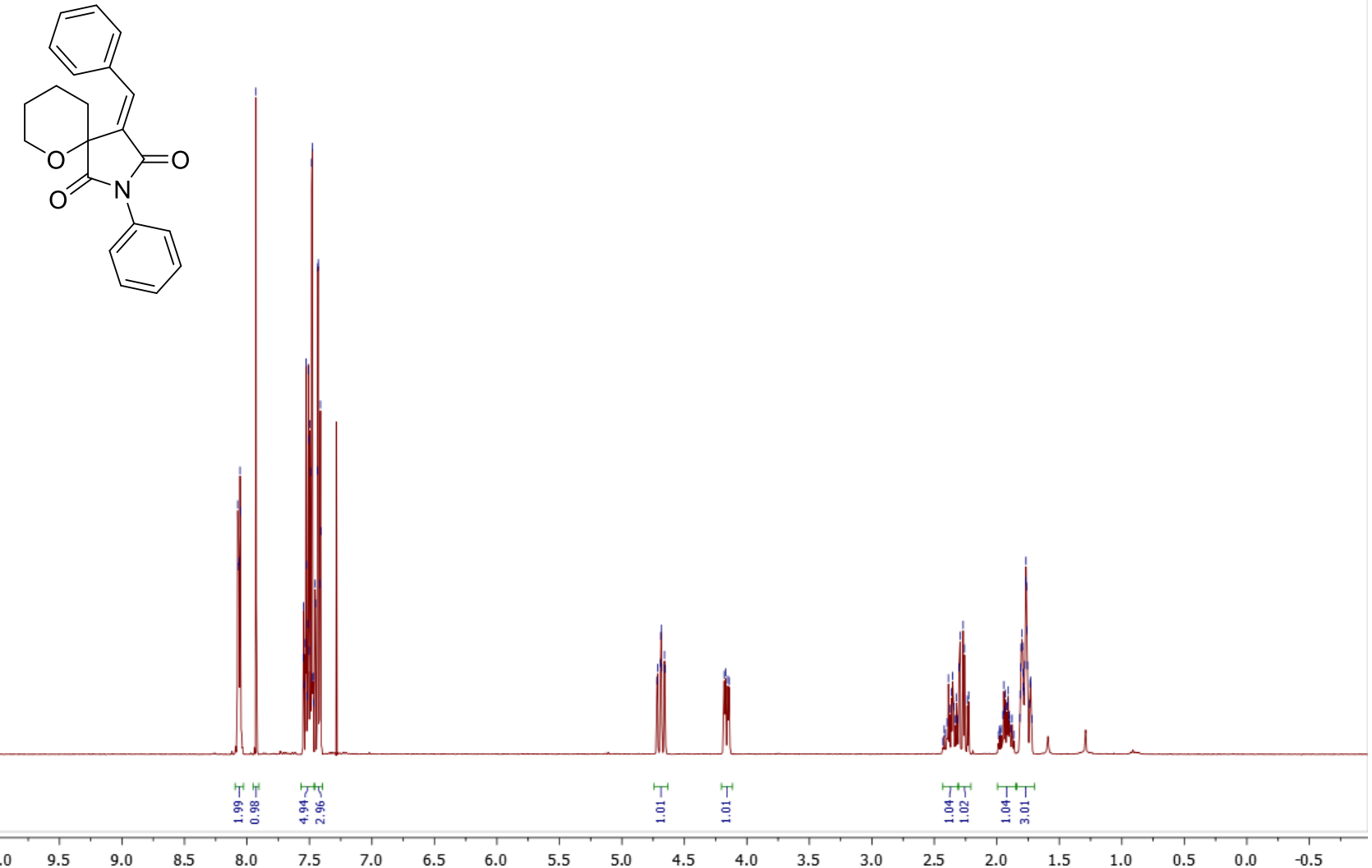



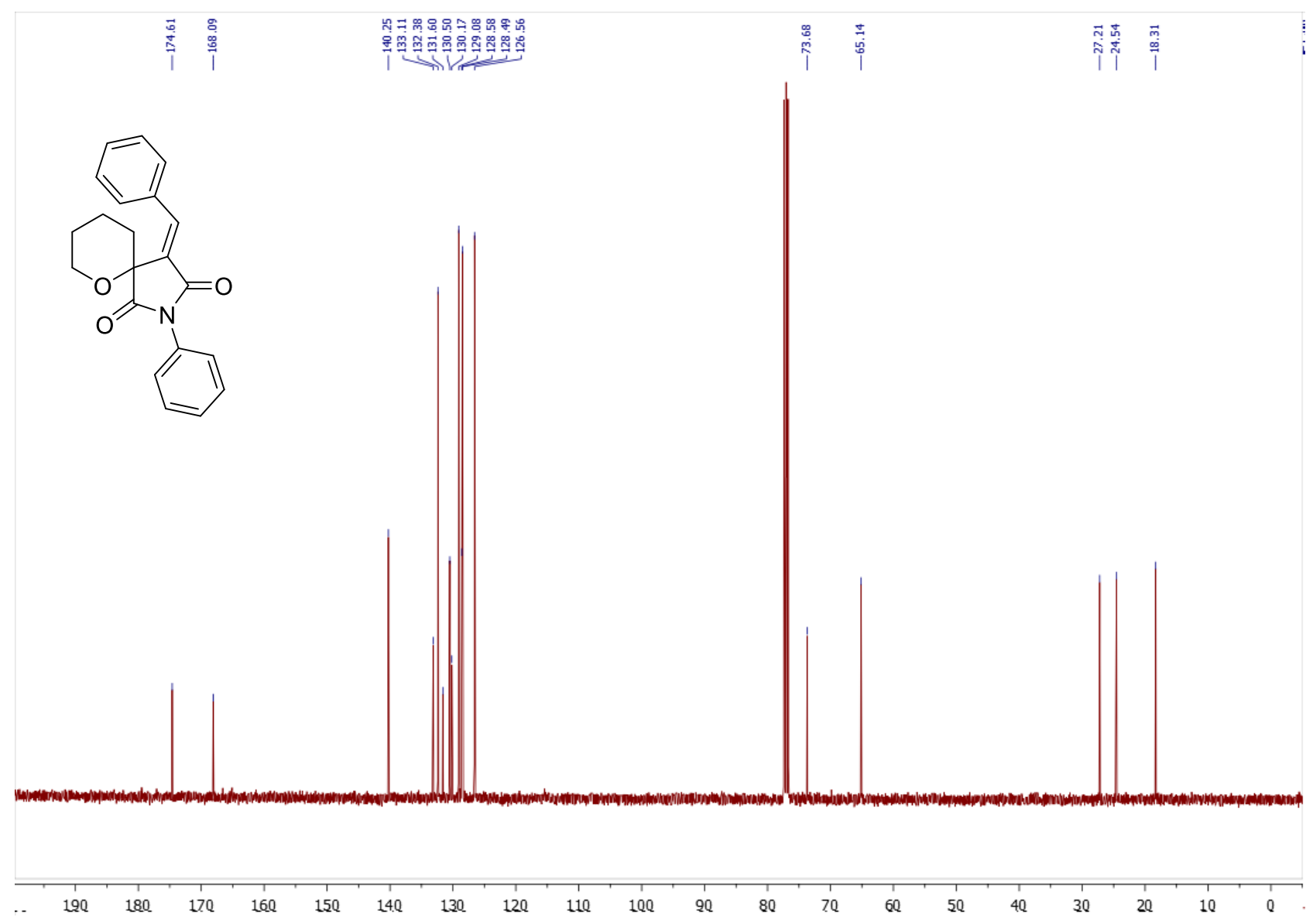

Copies of ${ }^{1} \mathrm{H}(400.13 \mathrm{MHz}, \mathrm{CDCl})$ and ${ }^{13} \mathrm{C}\left(100.61 \mathrm{MHz}, \mathrm{CDCl}_{3}\right)$ spectra of $(\boldsymbol{R} / \mathbf{S}, \boldsymbol{S} / \boldsymbol{R})-\mathbf{6} \mathbf{h}^{\mathrm{min}}$

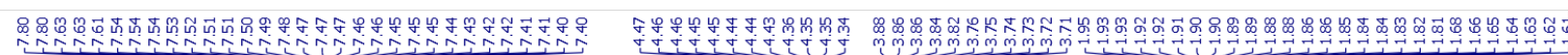

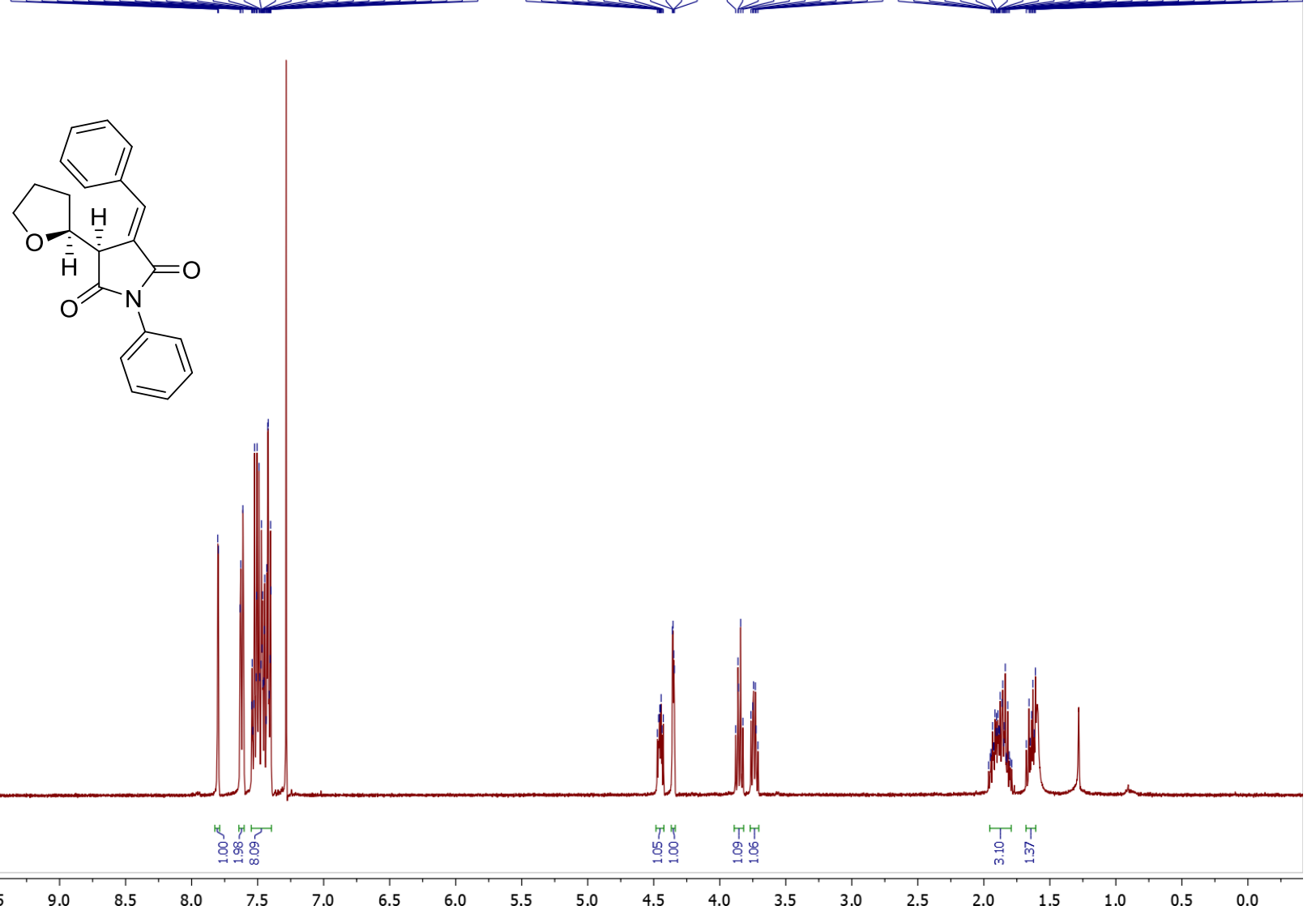




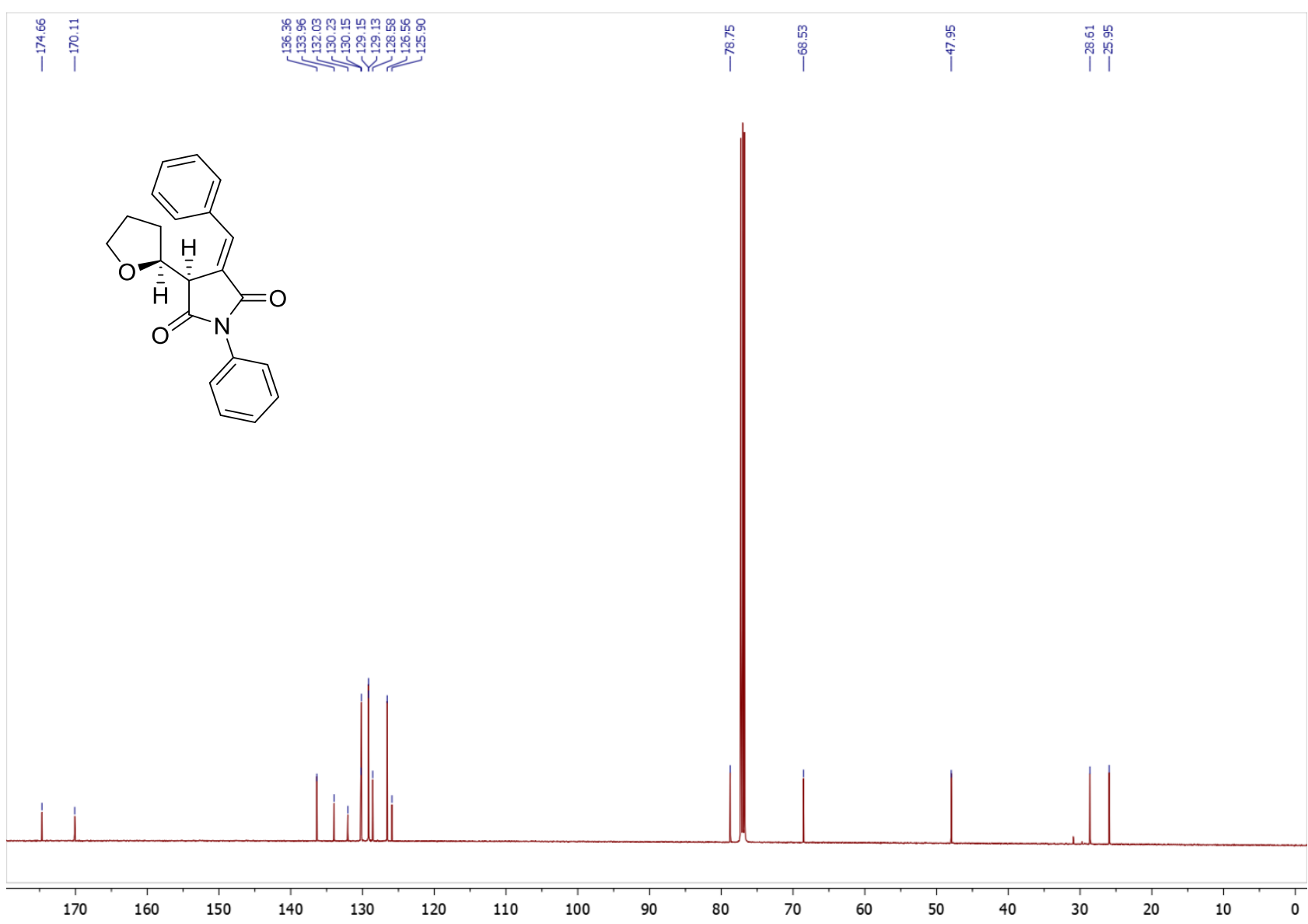

Copies of ${ }^{1} \mathrm{H}\left(400.13 \mathrm{MHz}, \mathrm{CDCl}_{3}\right)$ and ${ }^{13} \mathrm{C}\left(100.61 \mathrm{MHz}, \mathrm{CDCl}_{3}\right)$ spectra of $(\boldsymbol{S} / \boldsymbol{R}, \boldsymbol{S} / \boldsymbol{R})-\mathbf{6} \mathbf{h}^{\text {maj }}$

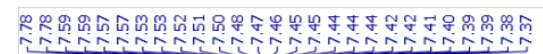

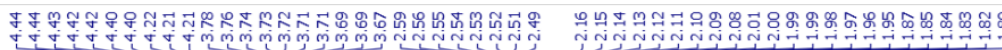<smiles>O=C1/C(=C/c2ccccc2)[C@H]([C@H]2CCCO2)C(=O)N1c1ccccc1</smiles>

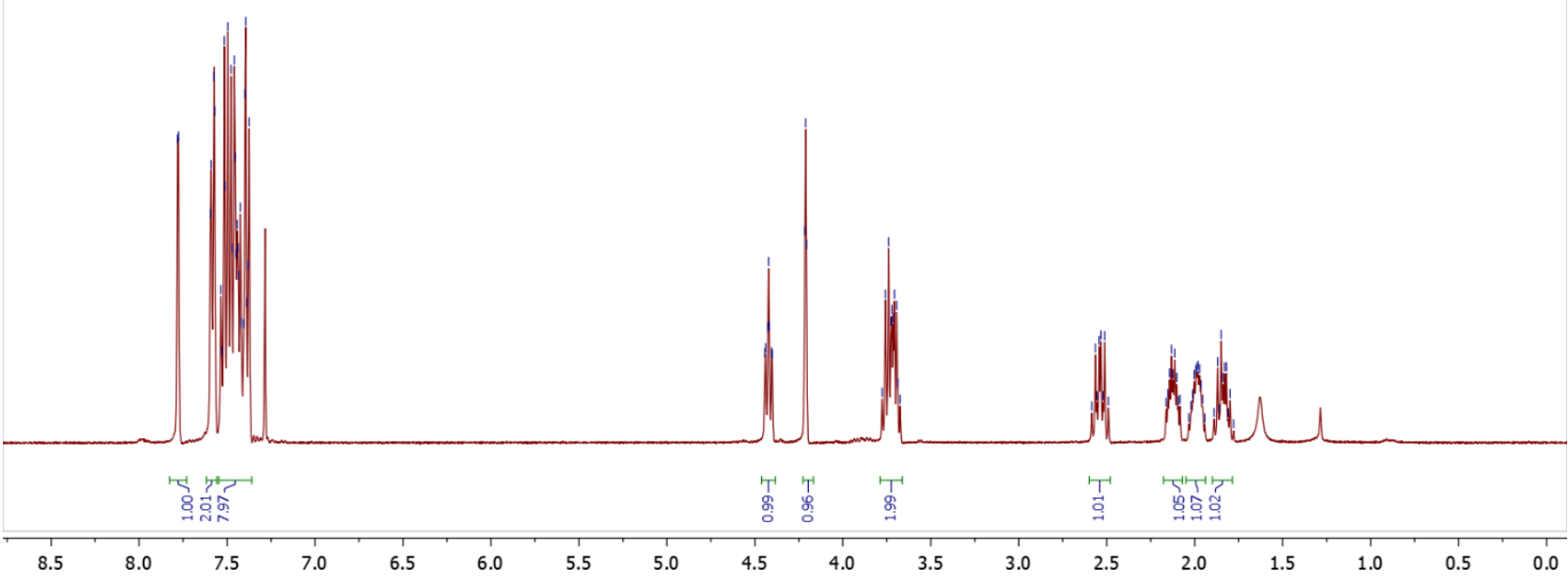




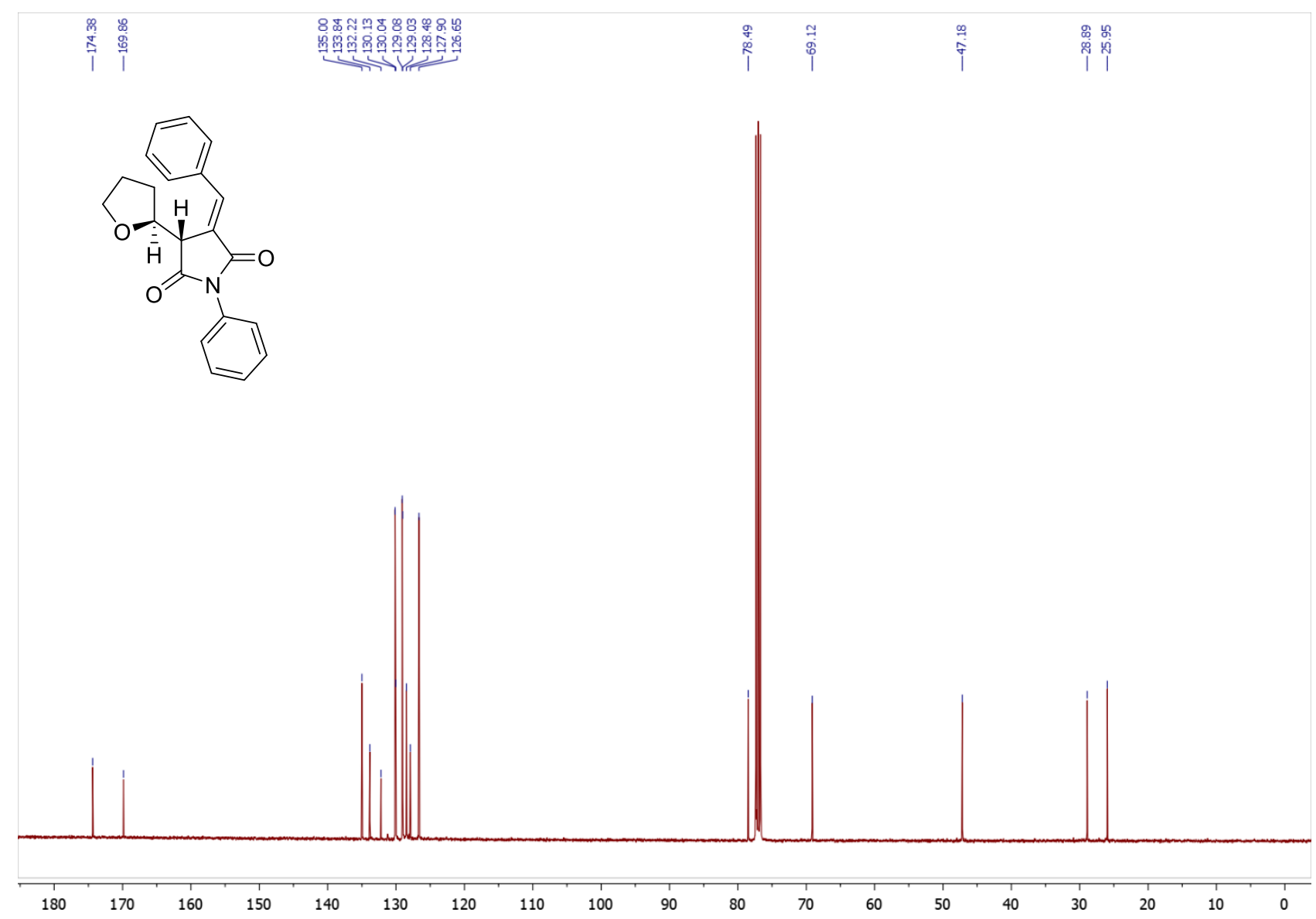

Copies of ${ }^{1} \mathrm{H}\left(400.13 \mathrm{MHz}, \mathrm{CDCl}_{3}\right)$ and ${ }^{13} \mathrm{C}\left(100.61 \mathrm{MHz}, \mathrm{CDCl}_{3}\right)$ spectra of $\mathbf{2 i}$

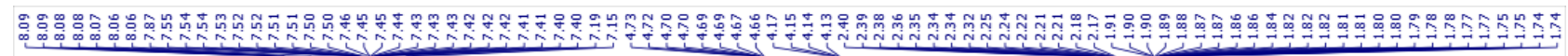

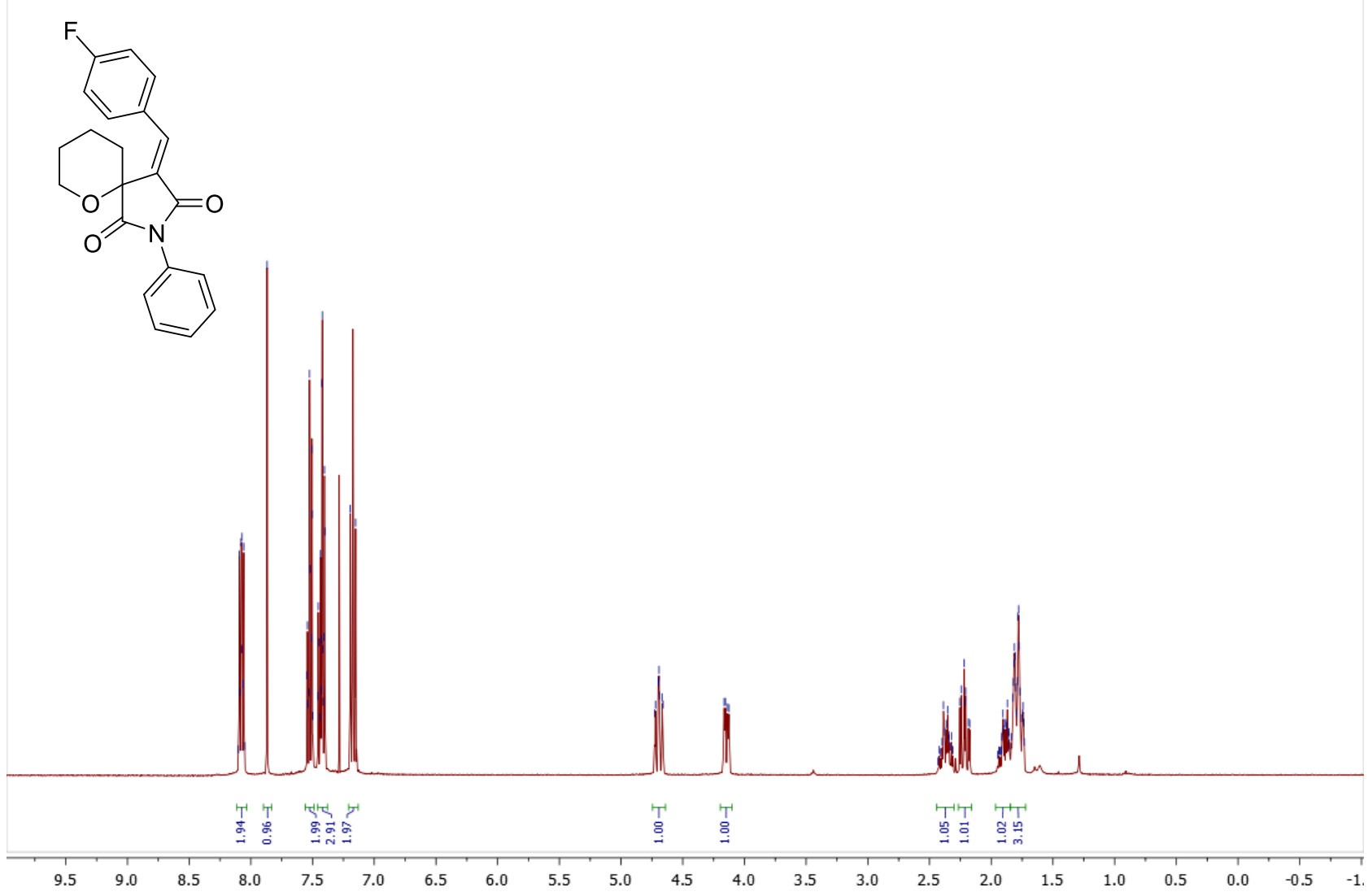



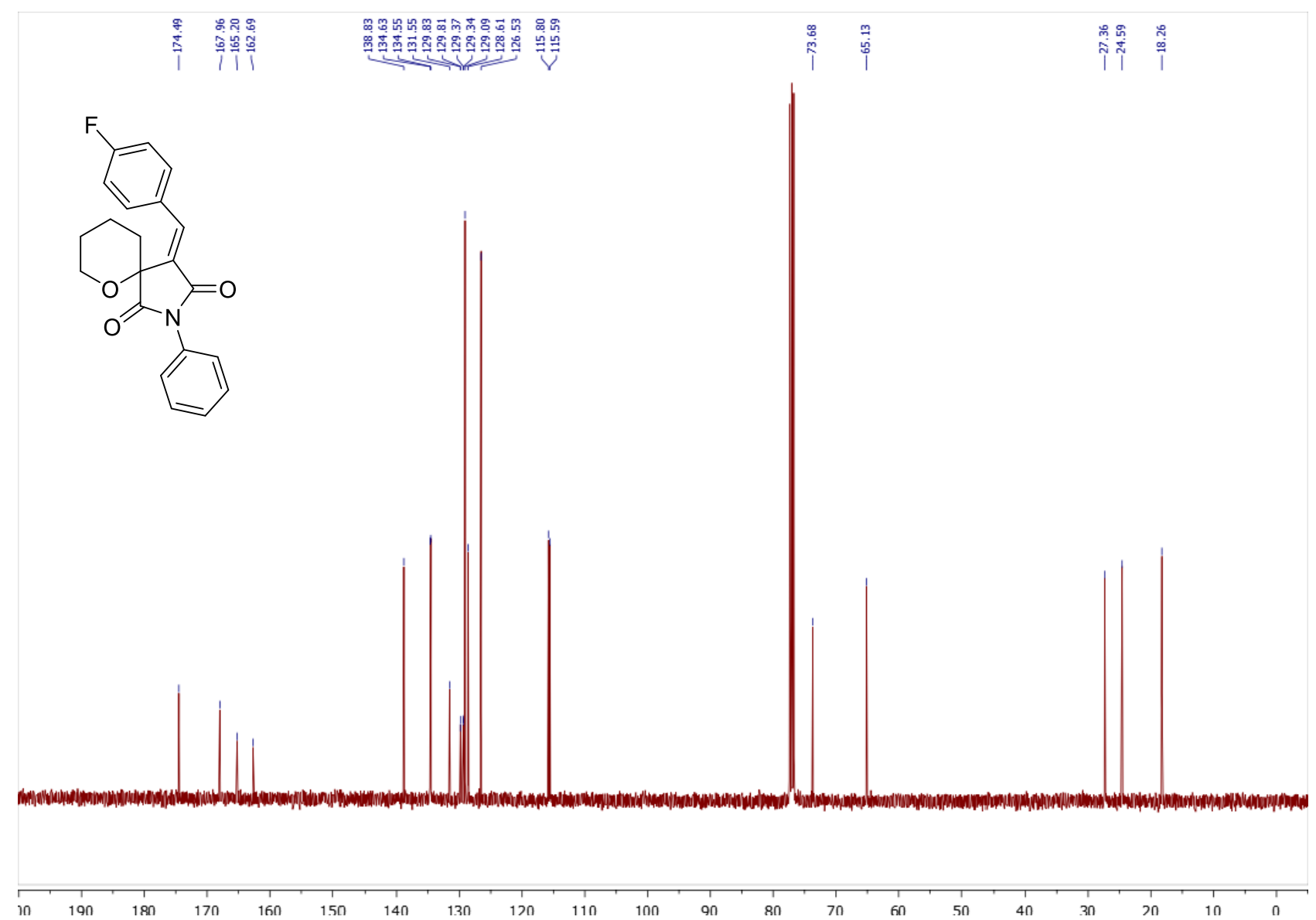

Copy of ${ }^{19} \mathrm{~F}\left(376.50 \mathrm{MHz}, \mathrm{CDCl}_{3}\right)$ spectrum of $\mathbf{2 i}$

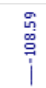

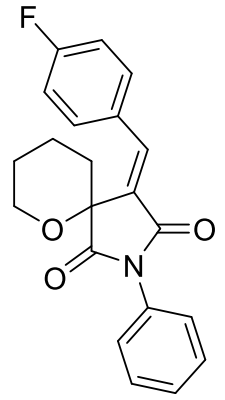

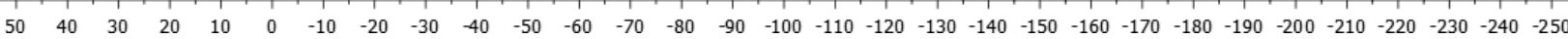


Copies of ${ }^{1} \mathrm{H}\left(400.13 \mathrm{MHz}, \mathrm{CDCl}_{3}\right)$ and ${ }^{13} \mathrm{C}\left(100.61 \mathrm{MHz}, \mathrm{CDCl}_{3}\right)$ spectra of $\mathbf{2} \mathbf{j}$
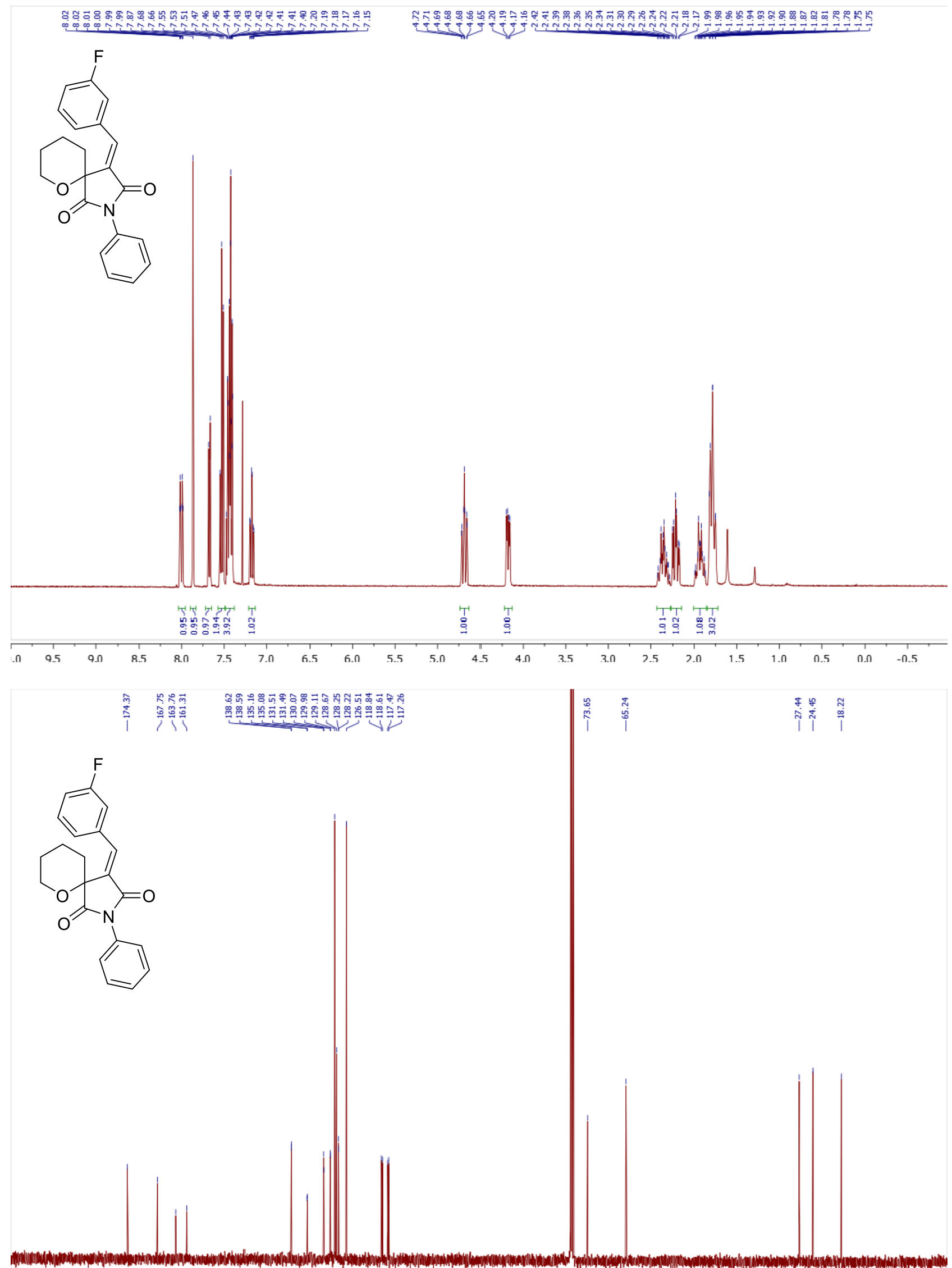

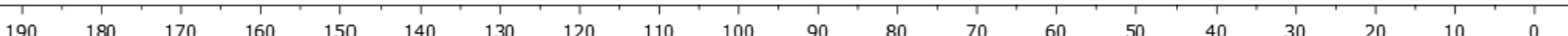


Copy of ${ }^{19} \mathrm{~F}\left(376.50 \mathrm{MHz}, \mathrm{CDCl}_{3}\right)$ spectrum of $\mathbf{2 j}$<smiles>O=C1C(=Cc2cccc(F)c2)C2(CCCCO2)C(=O)N1c1ccccc1</smiles> 
Copies of ${ }^{1} \mathrm{H}\left(400.13 \mathrm{MHz}, \mathrm{CDCl}_{3}\right)$ and ${ }^{13} \mathrm{C}\left(100.61 \mathrm{MHz}, \mathrm{CDCl}_{3}\right)$ spectra of $\mathbf{2 k}$
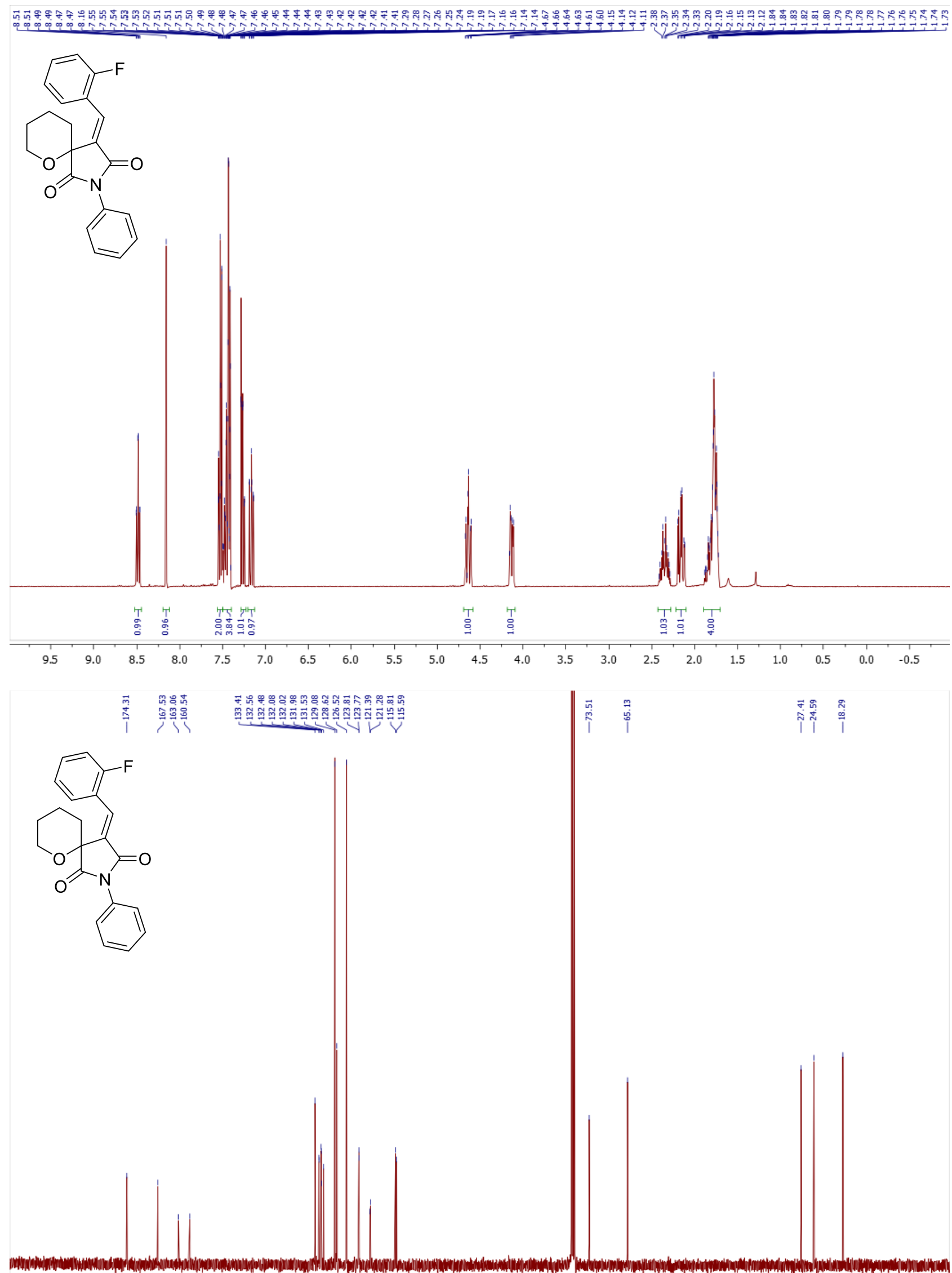

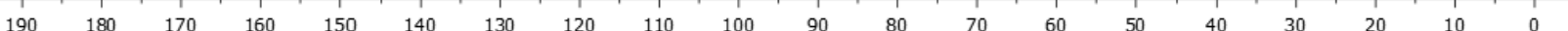


Copy of ${ }^{19} \mathrm{~F}\left(376.50 \mathrm{MHz}, \mathrm{CDCl}_{3}\right)$ spectrum of $\mathbf{2 k}$<smiles>O=C1/C(=C/c2ccccc2F)C2(CCCCO2)C(=O)N1c1ccccc1</smiles>

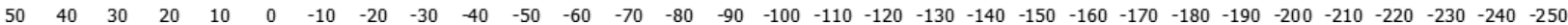


Copies of ${ }^{1} \mathrm{H}\left(400.13 \mathrm{MHz}, \mathrm{CDCl}_{3}\right)$ and ${ }^{13} \mathrm{C}\left(100.61 \mathrm{MHz}, \mathrm{CDCl}_{3}\right)$ spectra of $2 \mathbf{I}$

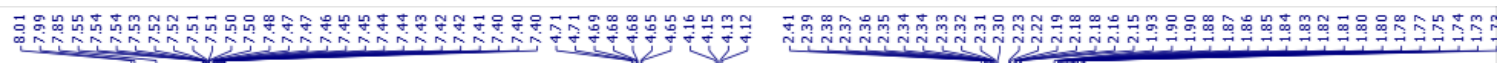

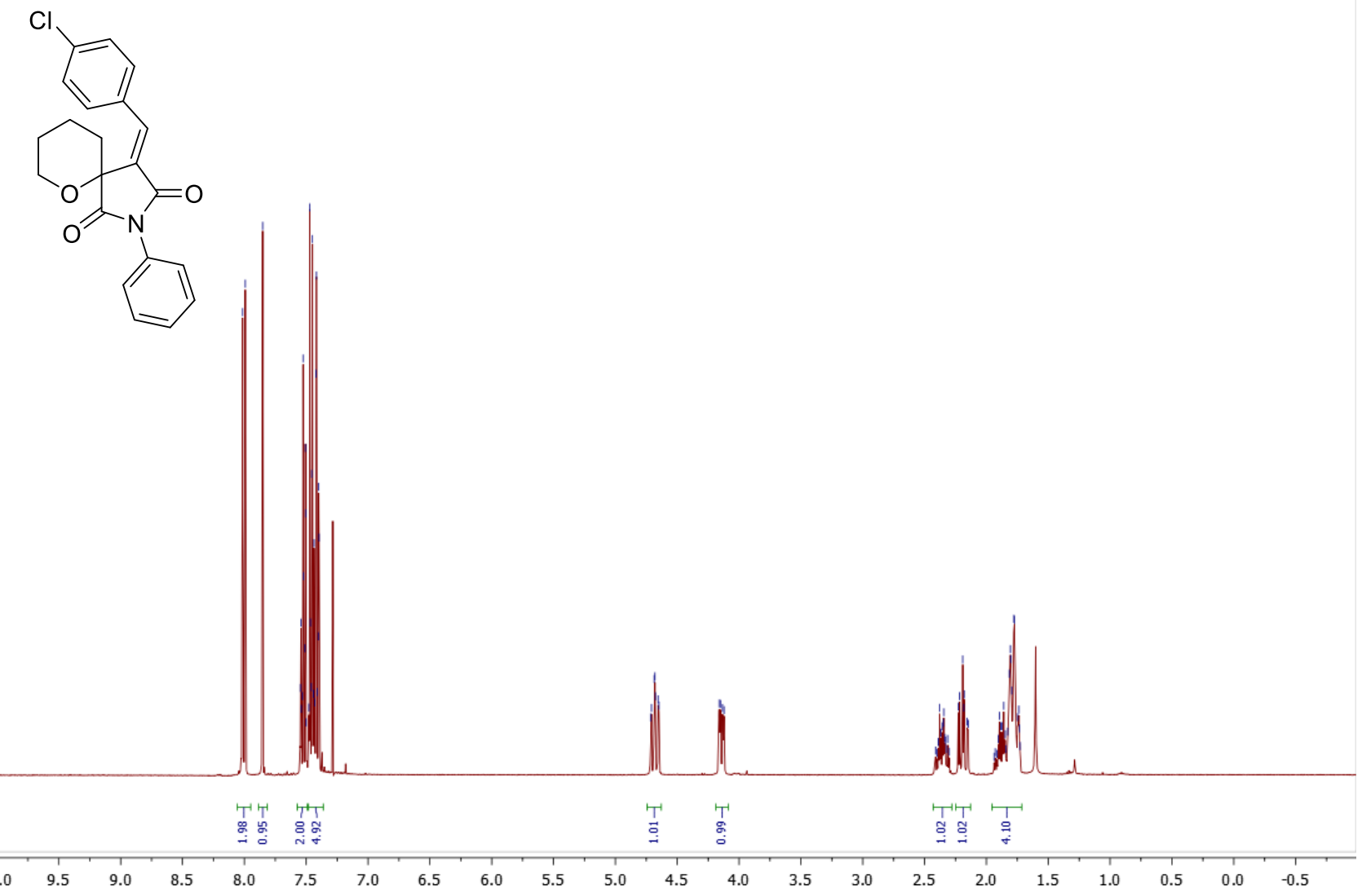

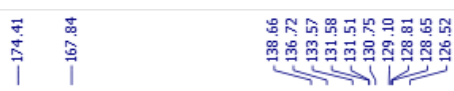

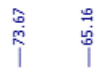

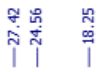

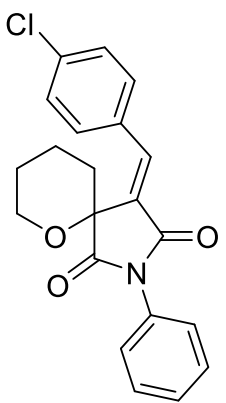

$\begin{array}{llll}190 & 180 & 170 & 160\end{array}$
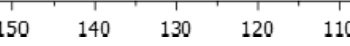
Copies of ${ }^{1} \mathrm{H}\left(400.13 \mathrm{MHz}, \mathrm{CDCl}_{3}\right)$ and ${ }^{13} \mathrm{C}\left(100.61 \mathrm{MHz}, \mathrm{CDCl}_{3}\right)$ spectra of $(\boldsymbol{R} / \boldsymbol{S}, \boldsymbol{S} / \boldsymbol{R})-\mathbf{6}^{\mathrm{min}}$
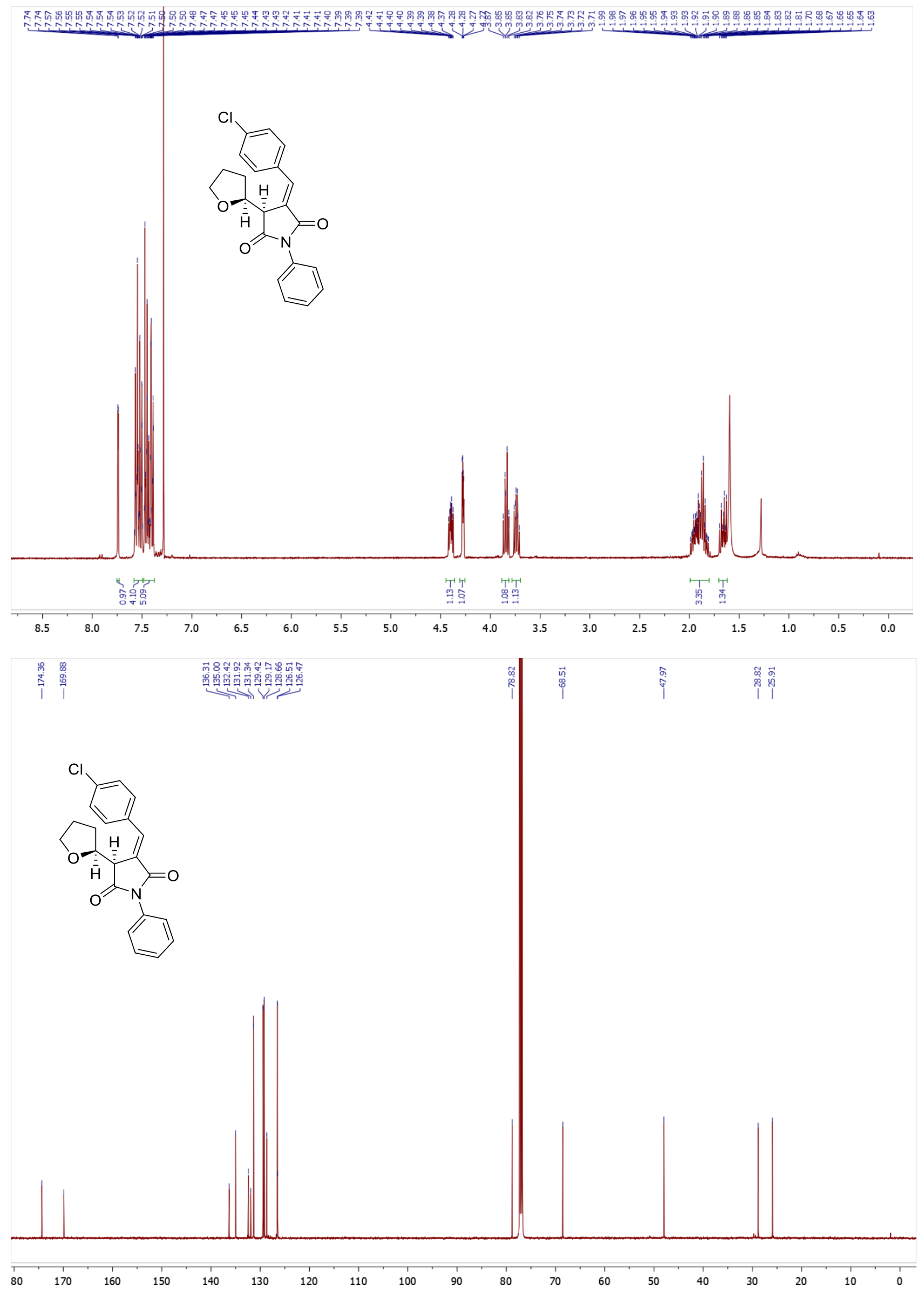
Copies of ${ }^{1} \mathrm{H}\left(400.13 \mathrm{MHz}, \mathrm{CDCl}_{3}\right)$ and ${ }^{13} \mathrm{C}\left(100.61 \mathrm{MHz}, \mathrm{CDCl}_{3}\right)$ spectra of $(\boldsymbol{S} / \boldsymbol{R}, \boldsymbol{S} / \boldsymbol{R})-\mathbf{6}^{\text {maj }}$

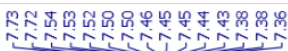

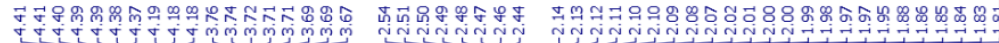
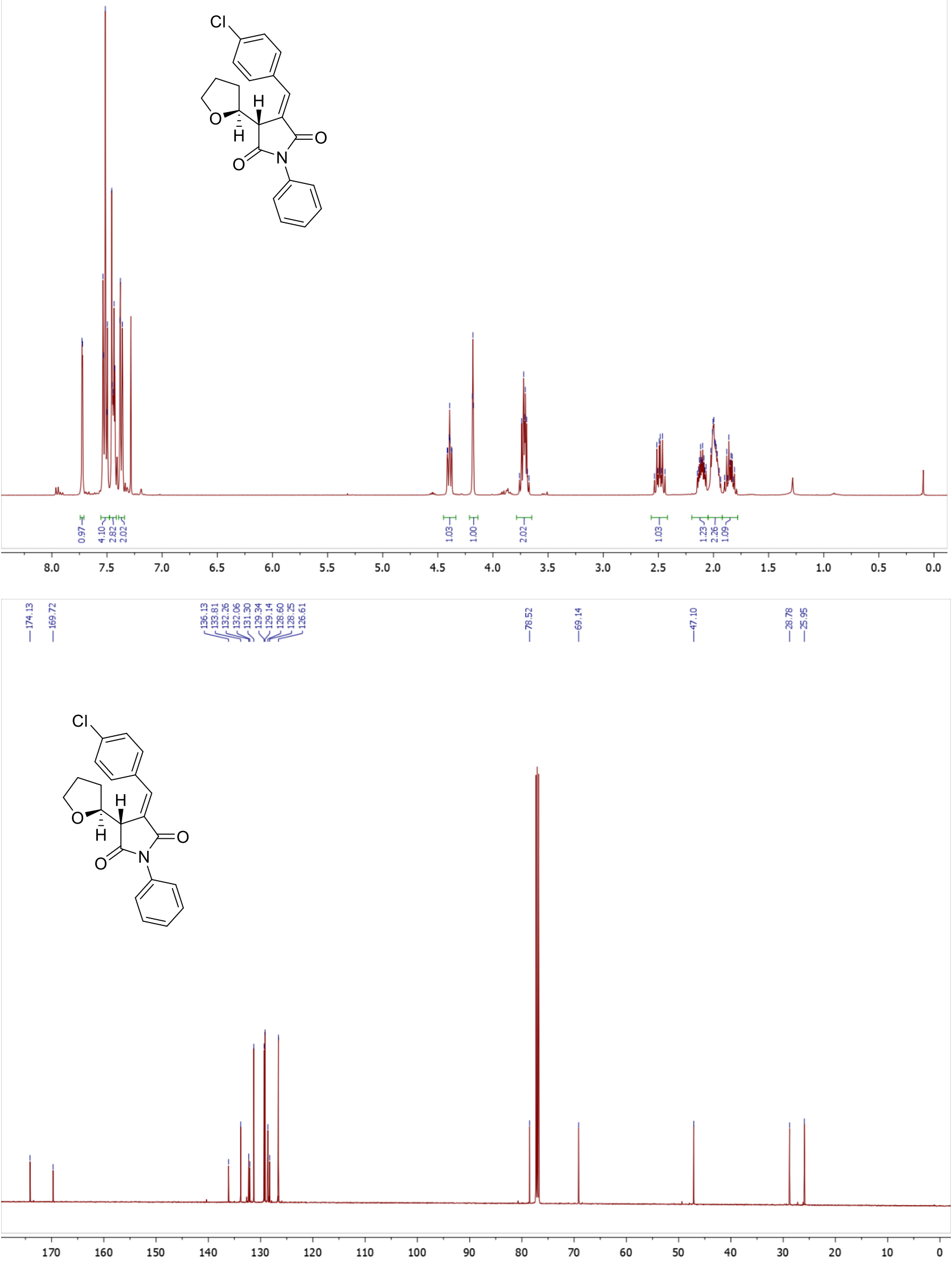
Copies of ${ }^{1} \mathrm{H}\left(400.13 \mathrm{MHz}, \mathrm{CDCl}_{3}\right)$ and ${ }^{13} \mathrm{C}\left(100.61 \mathrm{MHz}, \mathrm{CDCl}_{3}\right)$ spectra of $\mathbf{2 m}$
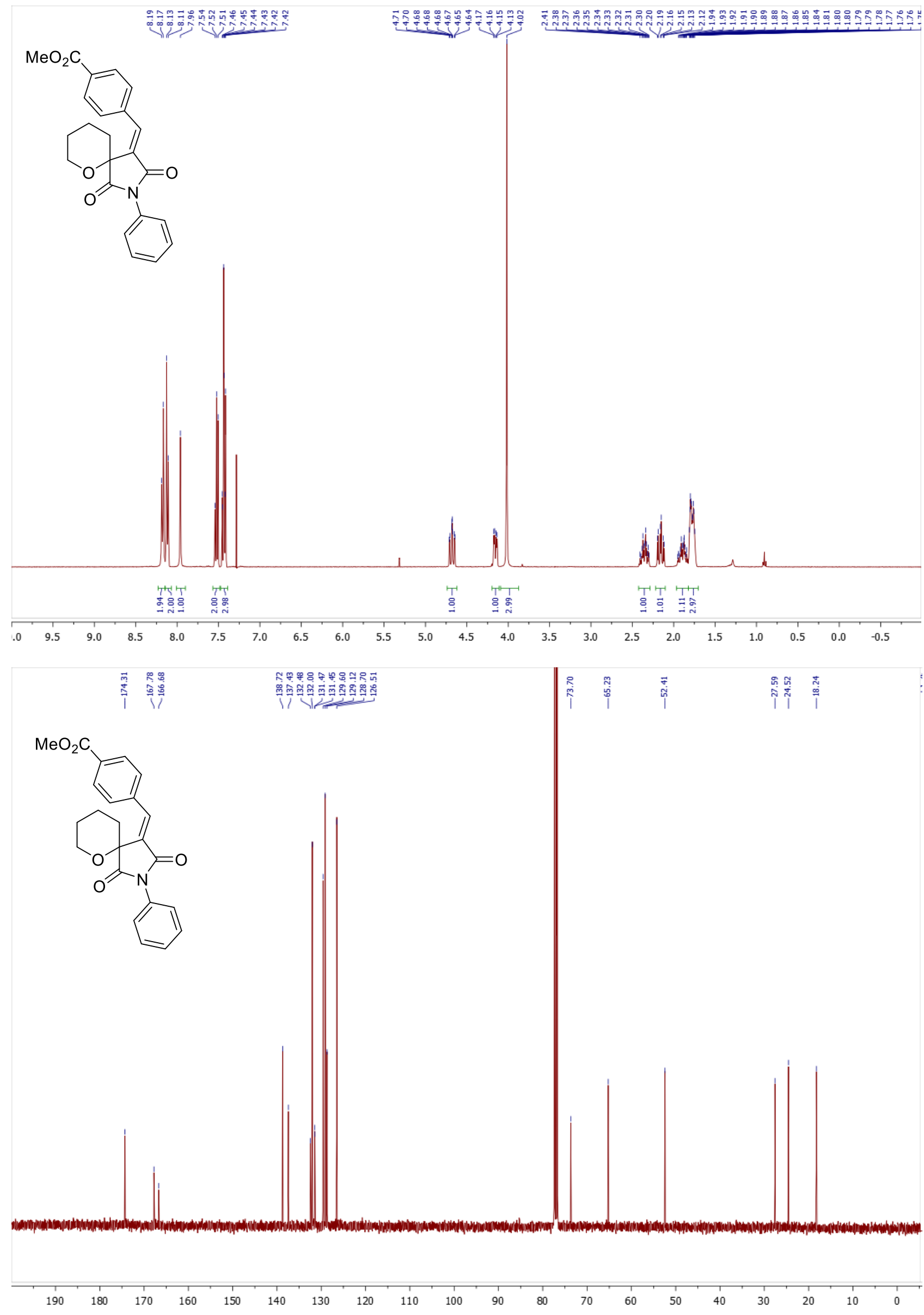
Copies of ${ }^{1} \mathrm{H}\left(400.13 \mathrm{MHz}, \mathrm{CDCl}_{3}\right)$ and ${ }^{13} \mathrm{C}\left(100.61 \mathrm{MHz}, \mathrm{CDCl}_{3}\right)$ spectra of $\mathbf{2 n}$
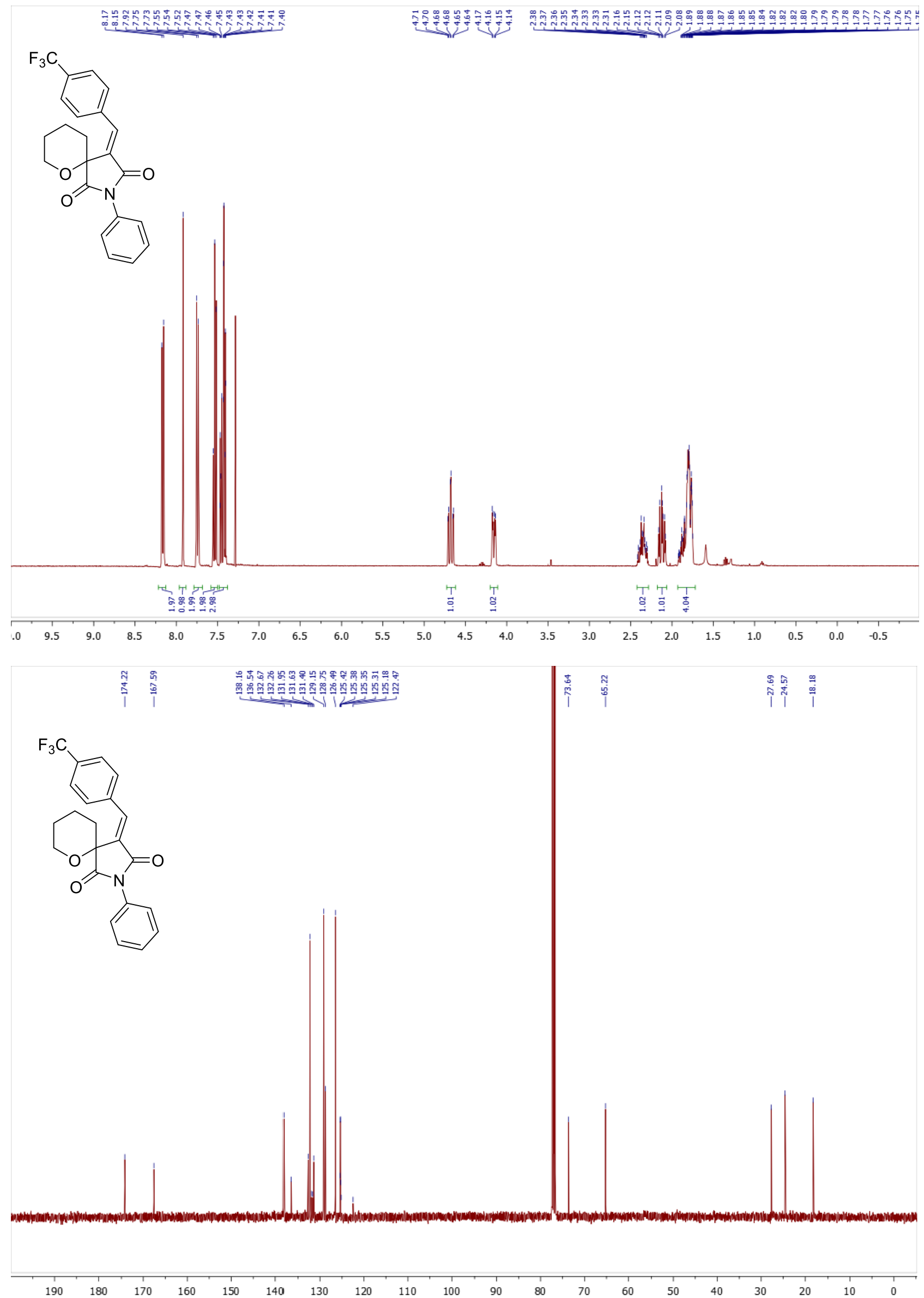
Copy of ${ }^{19} \mathrm{~F}\left(376.50 \mathrm{MHz}, \mathrm{CDCl}_{3}\right)$ spectrum of $\mathbf{2 n}$

iุ

$\mathrm{F}_{3} \mathrm{C}$<smiles>Cc1ccc(C=C2C(=O)C(=O)N(c3ccccc3)C2=O)cc1</smiles>

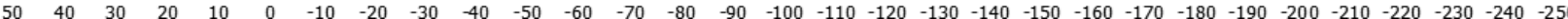


Copies of ${ }^{1} \mathrm{H}\left(400.13 \mathrm{MHz}, \mathrm{CDCl}_{3}\right)$ and ${ }^{13} \mathrm{C}\left(100.61 \mathrm{MHz}, \mathrm{CDCl}_{3}\right)$ spectra of 20
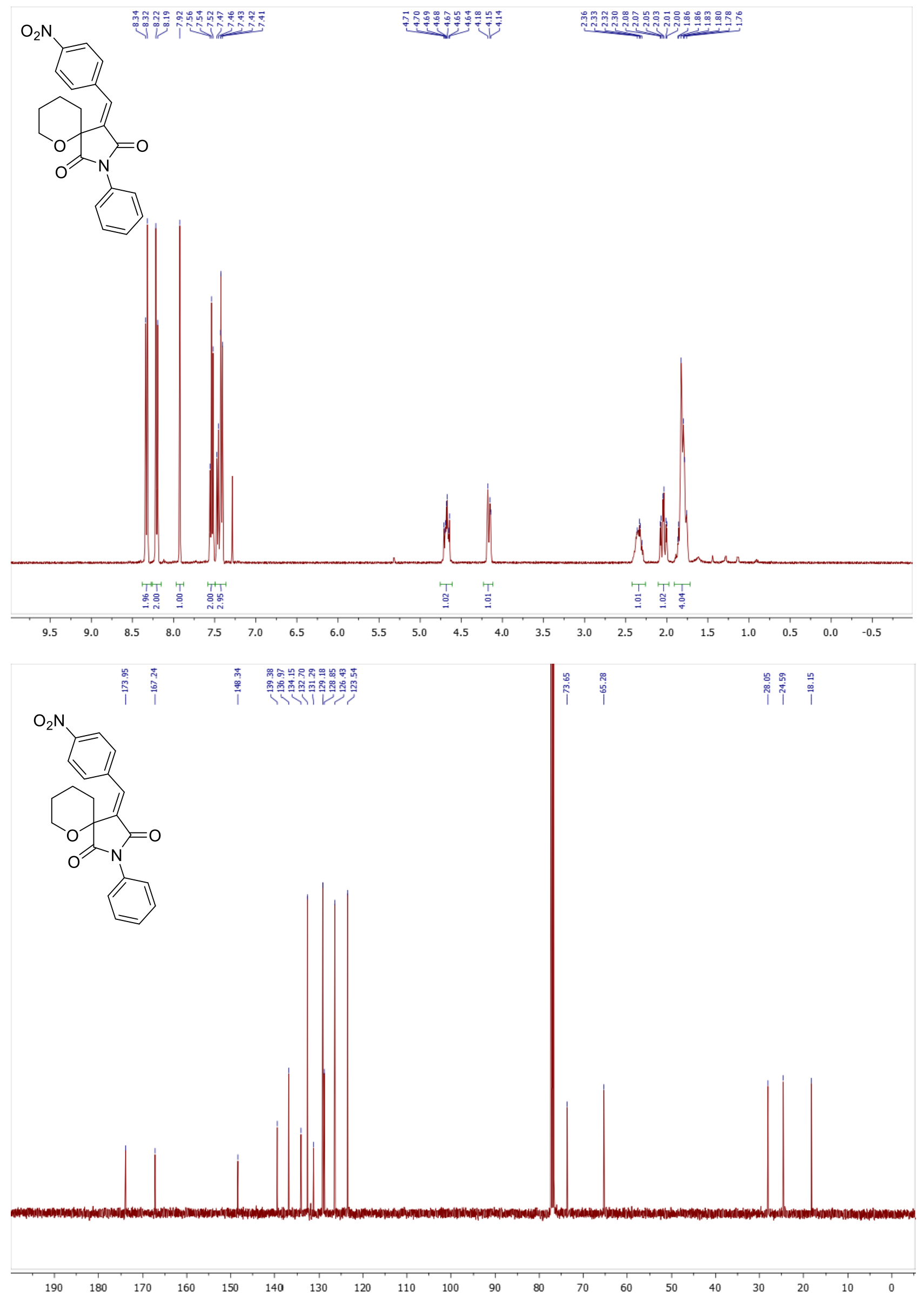
Copies of ${ }^{1} \mathrm{H}\left(400.13 \mathrm{MHz}, \mathrm{CDCl}_{3}\right)$ and ${ }^{13} \mathrm{C}\left(100.61 \mathrm{MHz}, \mathrm{CDCl}_{3}\right)$ spectra of $\mathbf{2 p}$

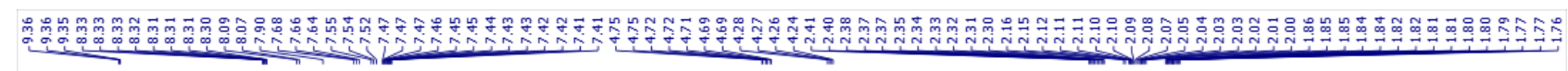
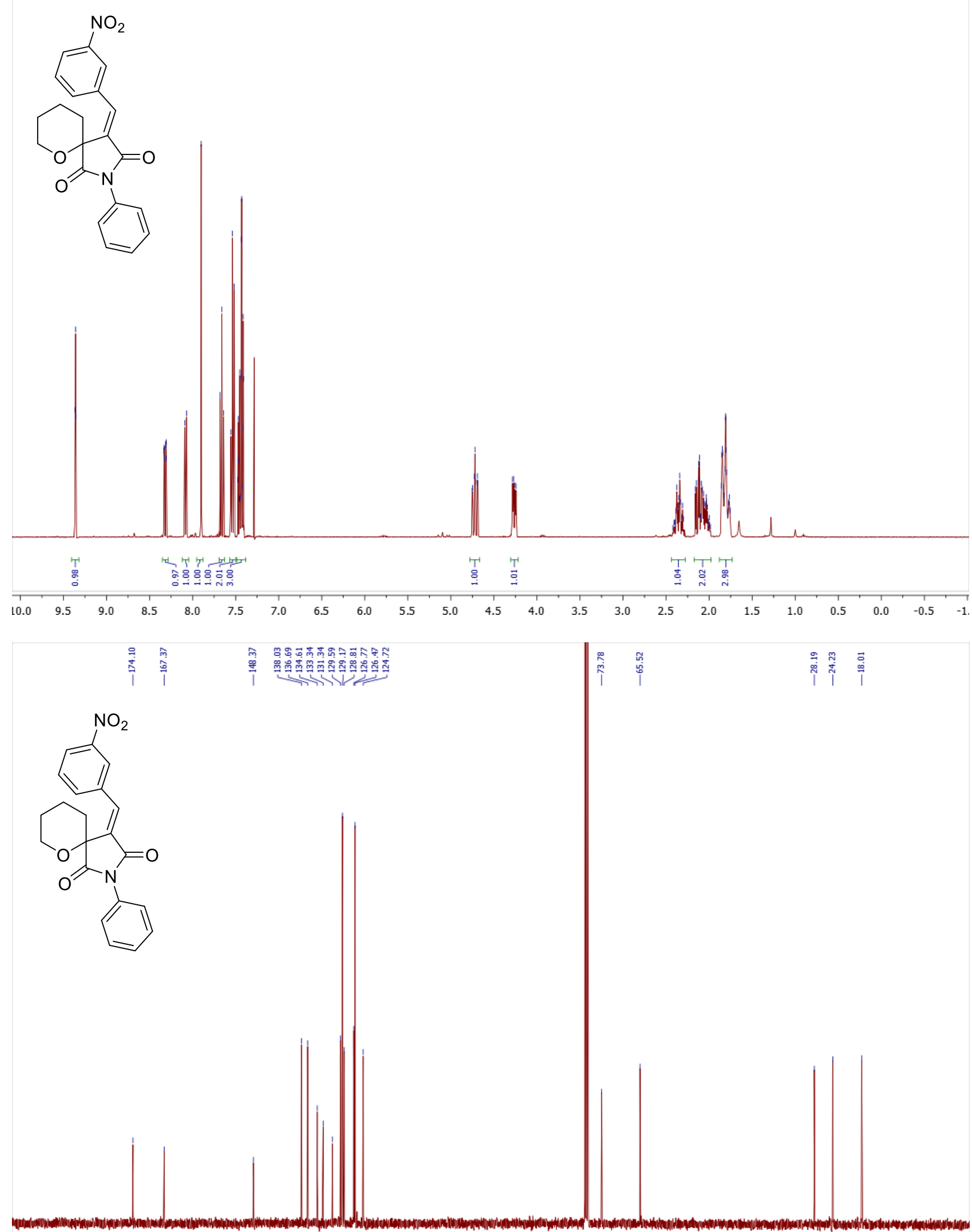

$\begin{array}{rrrrrrrrrrrrrrrrrrrr}1 & 1 \\ 190 & 180 & 170 & 160 & 150 & 140 & 130 & 120 & 110 & 100 & 90 & \mathbf{8} 0 & 70 & 60 & 50 & 40 & 30 & 20 & 10 & 0\end{array}$ 
Copies of ${ }^{1} \mathrm{H}\left(400.13 \mathrm{MHz}, \mathrm{CDCl}_{3}\right)$ and ${ }^{13} \mathrm{C}\left(100.61 \mathrm{MHz}, \mathrm{CDCl}_{3}\right)$ spectra of $\mathbf{2 q}$
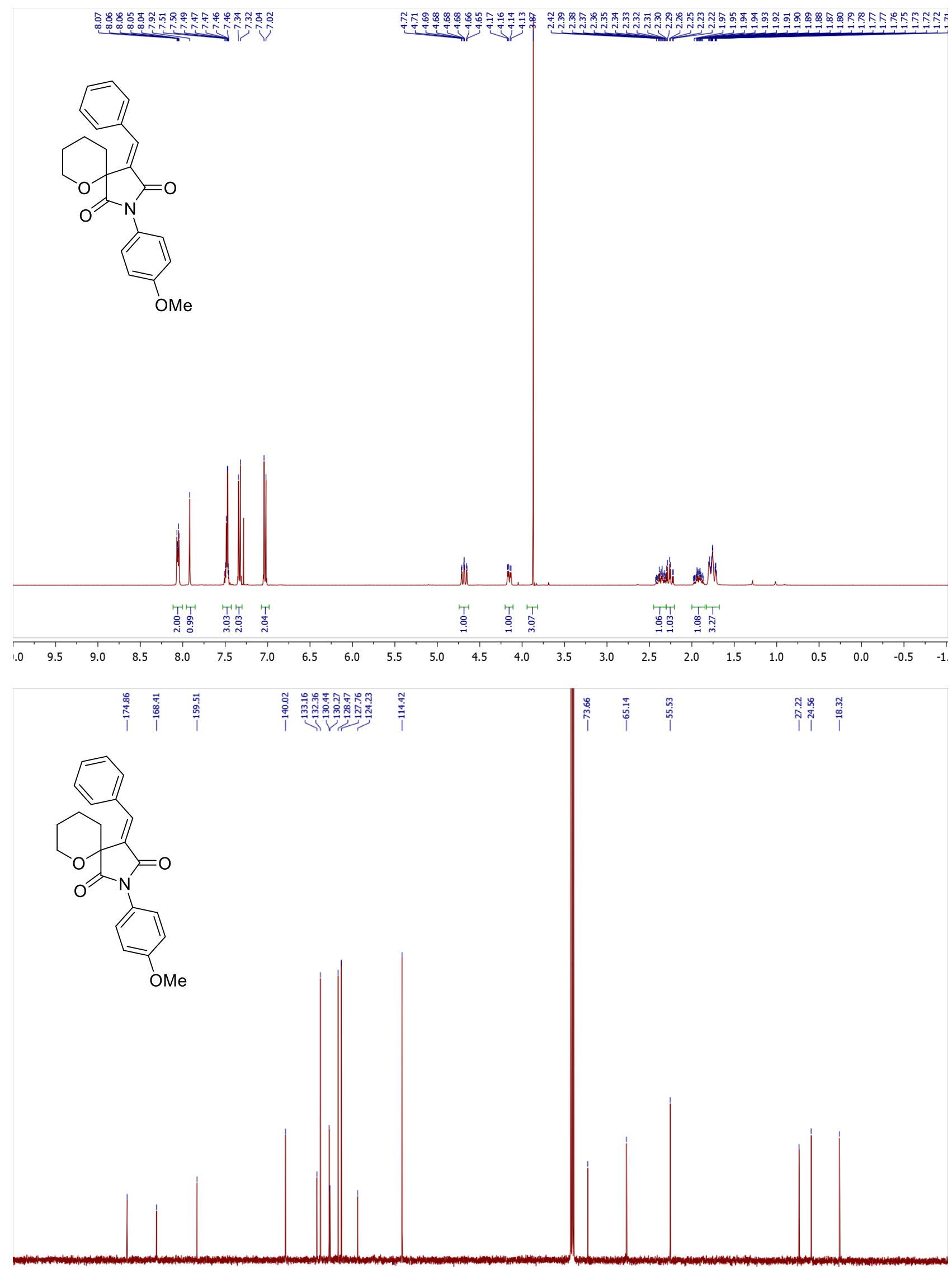

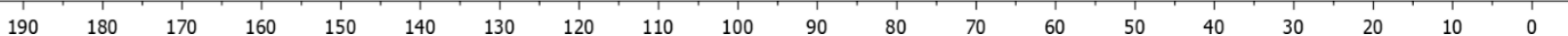


Copies of ${ }^{1} \mathrm{H}\left(400.13 \mathrm{MHz}, \mathrm{CDCl}_{3}\right)$ and ${ }^{13} \mathrm{C}\left(100.61 \mathrm{MHz}, \mathrm{CDCl}_{3}\right)$ spectra of $\mathbf{2 r}$
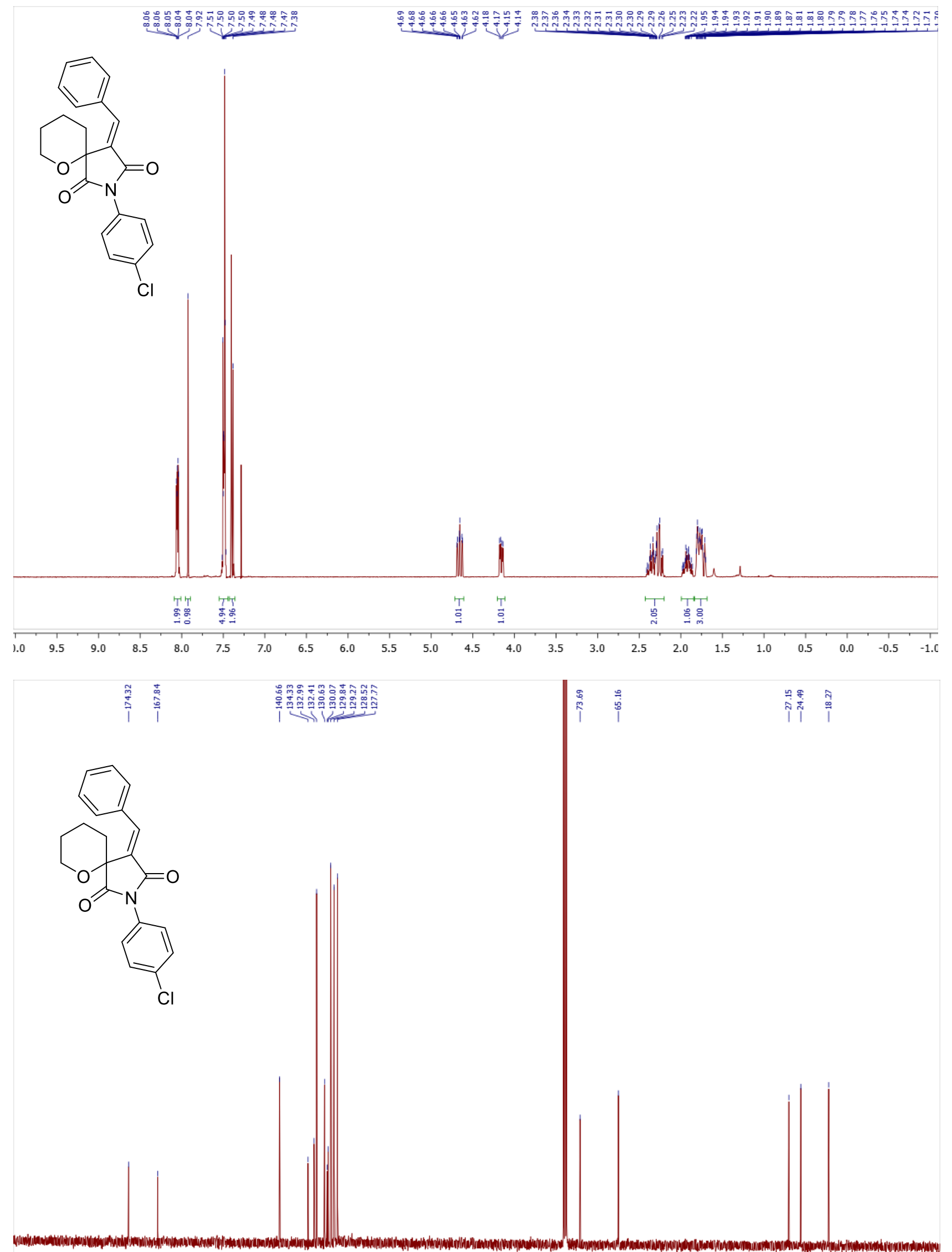

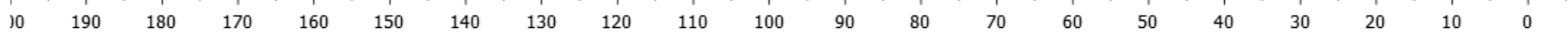


Copies of ${ }^{1} \mathrm{H}\left(400.13 \mathrm{MHz}, \mathrm{CDCl}_{3}\right)$ and ${ }^{13} \mathrm{C}\left(100.61 \mathrm{MHz}, \mathrm{CDCl}_{3}\right)$ spectra of $\mathbf{2 s}$
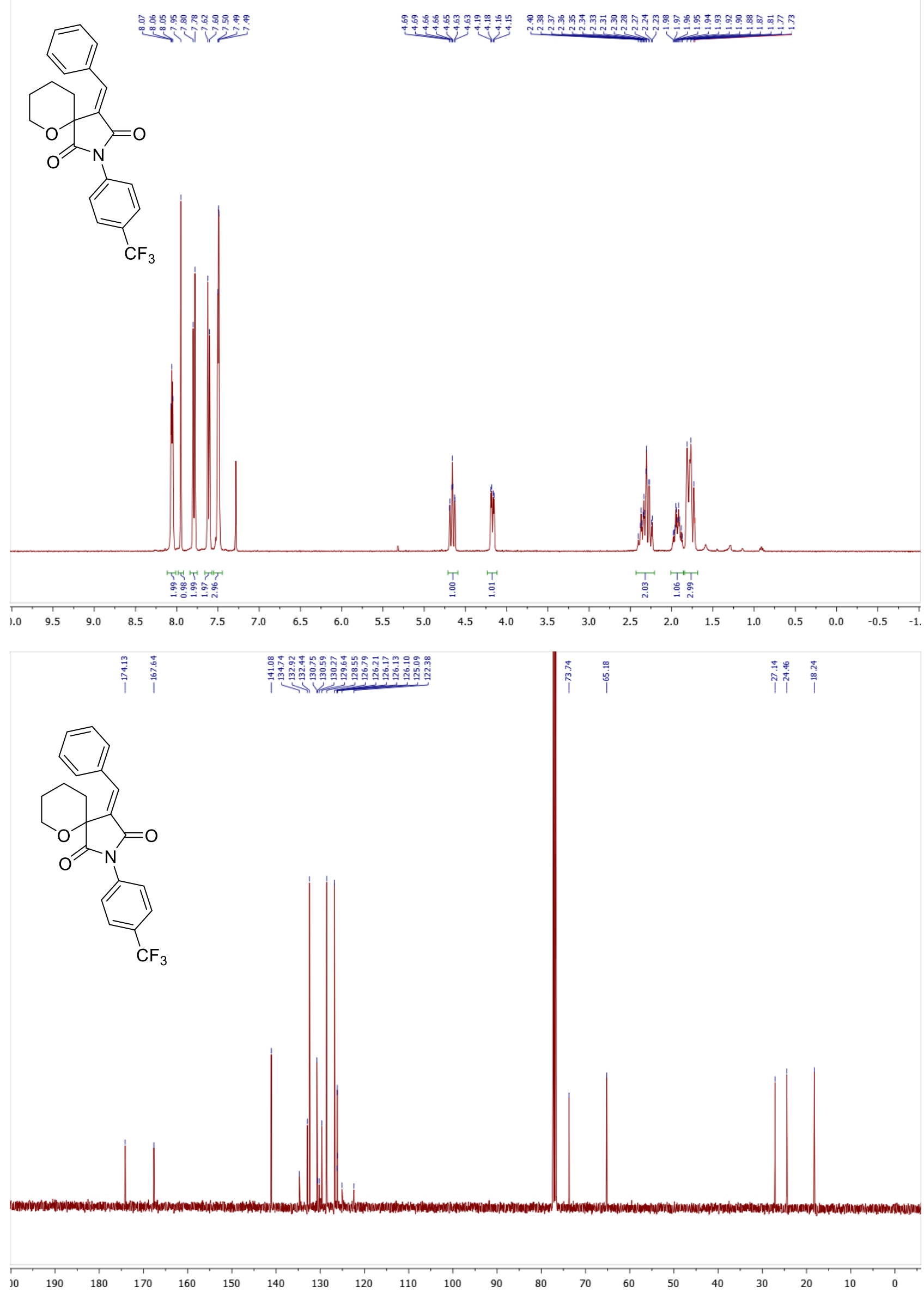
Copy of ${ }^{19} \mathrm{~F}\left(376.50 \mathrm{MHz}, \mathrm{CDCl}_{3}\right)$ spectrum of $2 \mathrm{~s}$

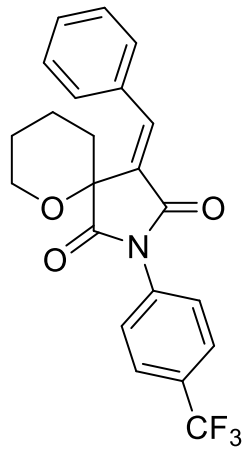

ָ̃

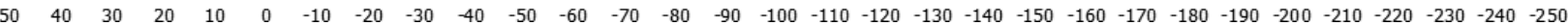


Copies of ${ }^{1} \mathrm{H}\left(400.13 \mathrm{MHz}, \mathrm{CDCl}_{3}\right)$ and ${ }^{13} \mathrm{C}\left(100.61 \mathrm{MHz}, \mathrm{CDCl}_{3}\right)$ spectra of $\mathbf{2 t}$

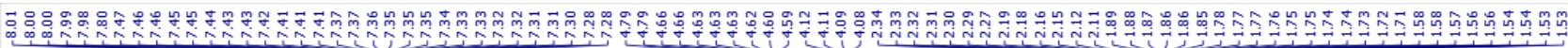
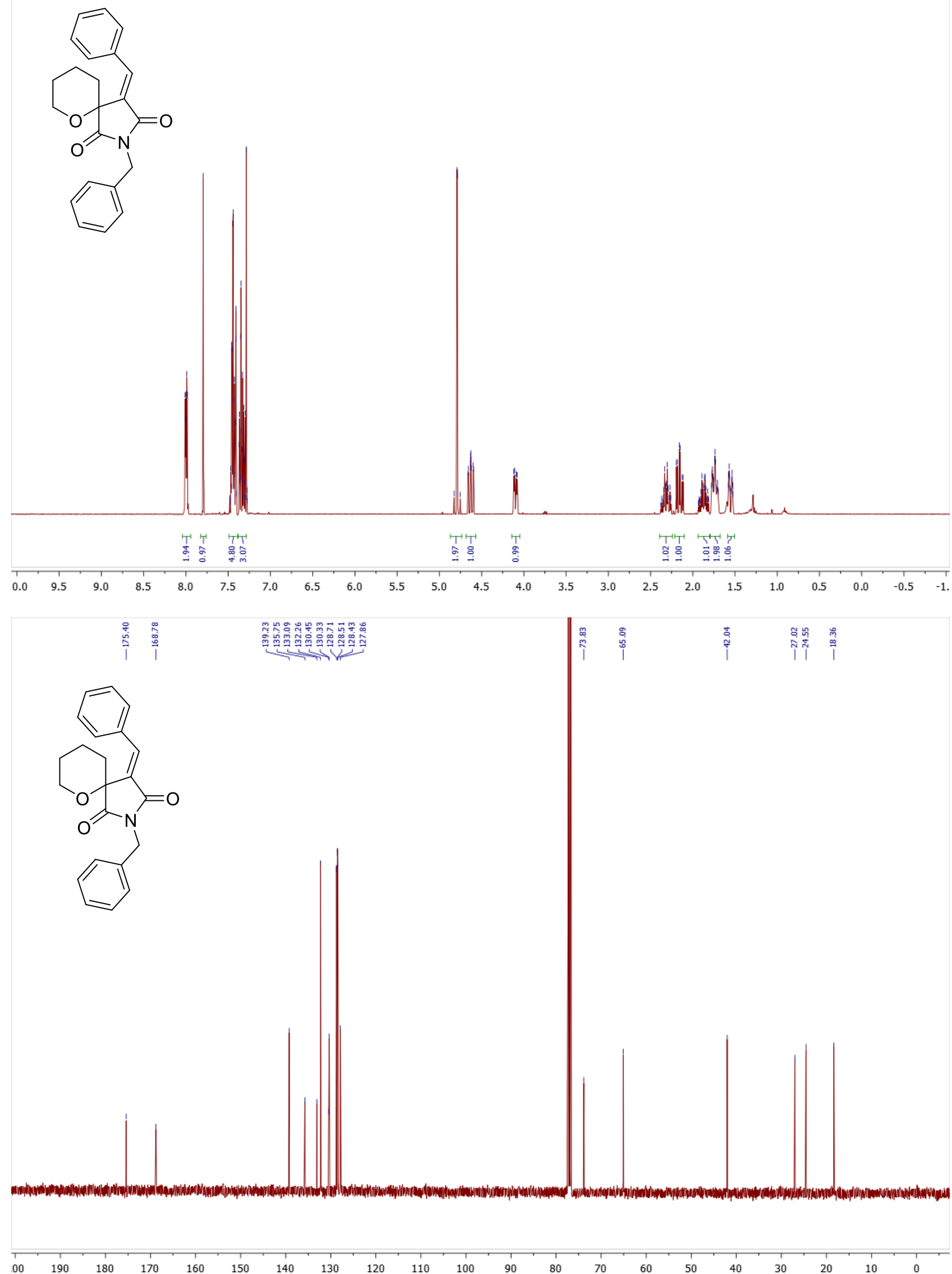
Copies of ${ }^{1} \mathrm{H}\left(400.13 \mathrm{MHz}, \mathrm{CDCl}_{3}\right)$ and ${ }^{13} \mathrm{C}\left(100.61 \mathrm{MHz}, \mathrm{CDCl}_{3}\right)$ spectra of $(\boldsymbol{R} / \mathbf{S}, \mathbf{S} / \boldsymbol{R})-\mathbf{6} \mathbf{t}^{\mathrm{min}}$

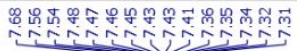

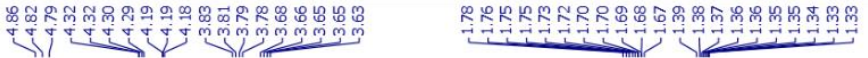

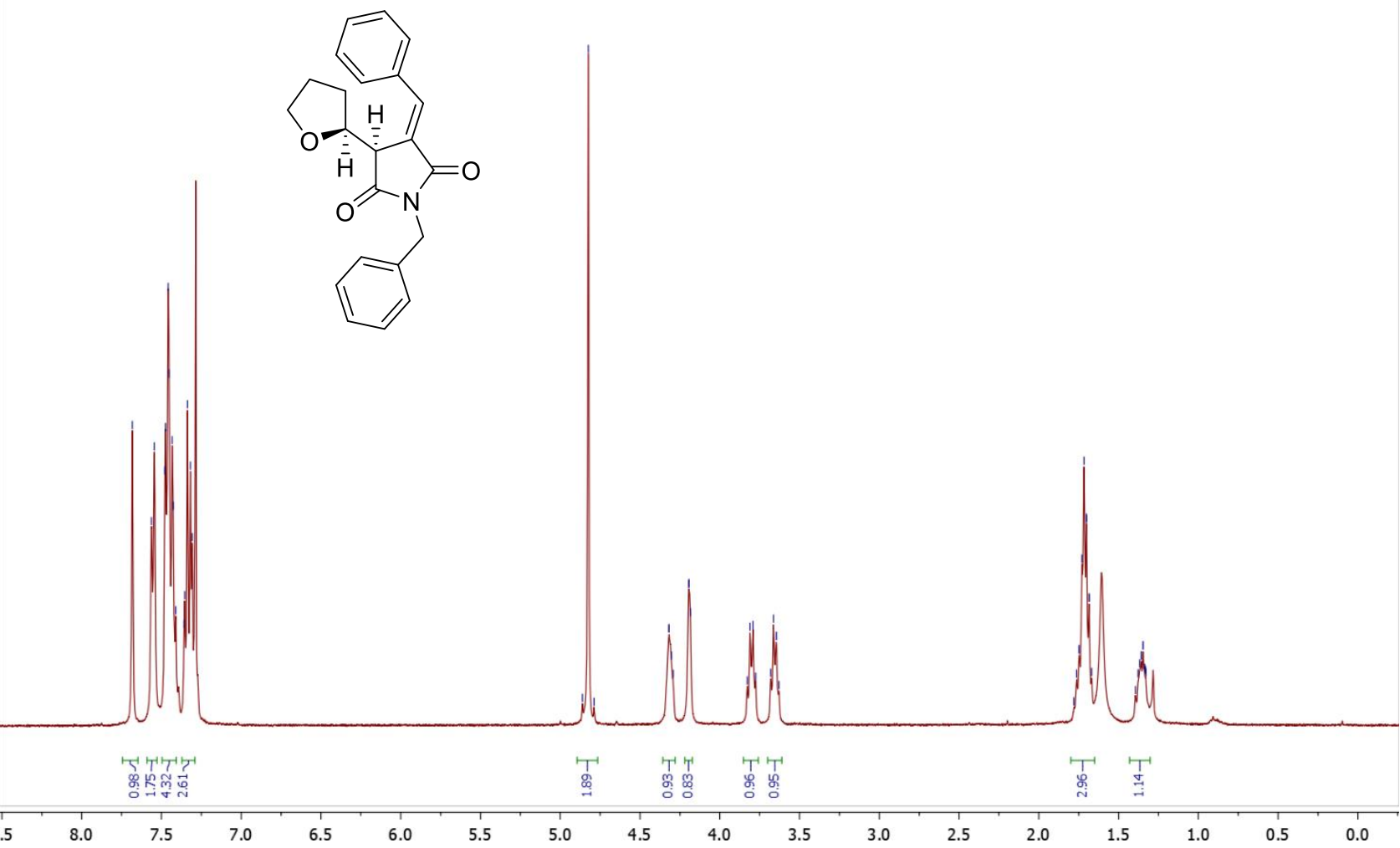

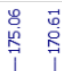

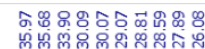

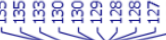
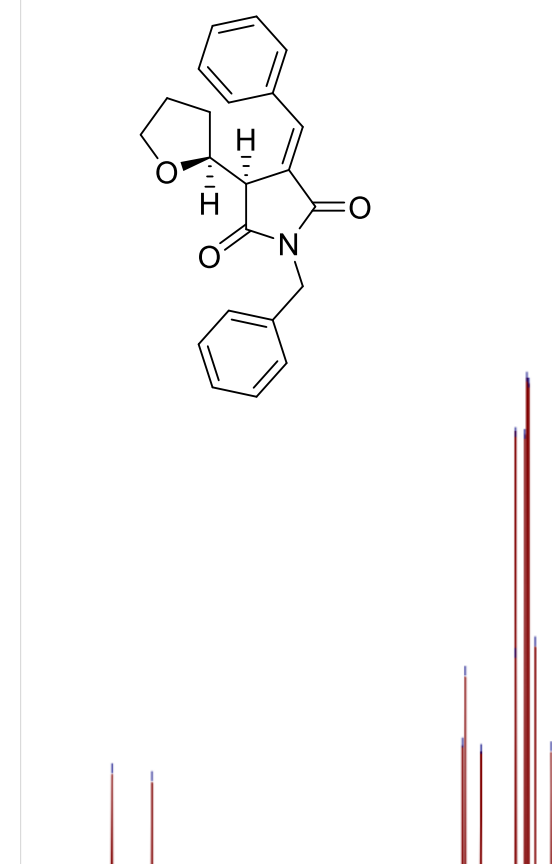
Copies of ${ }^{1} \mathrm{H}\left(400.13 \mathrm{MHz}, \mathrm{CDCl}_{3}\right)$ and ${ }^{13} \mathrm{C}\left(100.61 \mathrm{MHz}, \mathrm{CDCl}_{3}\right)$ spectra of $(\boldsymbol{S} / \boldsymbol{R}, \boldsymbol{S} / \boldsymbol{R})-\mathbf{6} \mathbf{t}^{\text {maj }}$

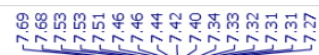

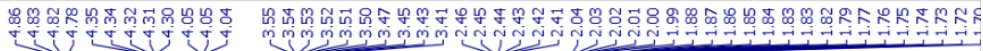

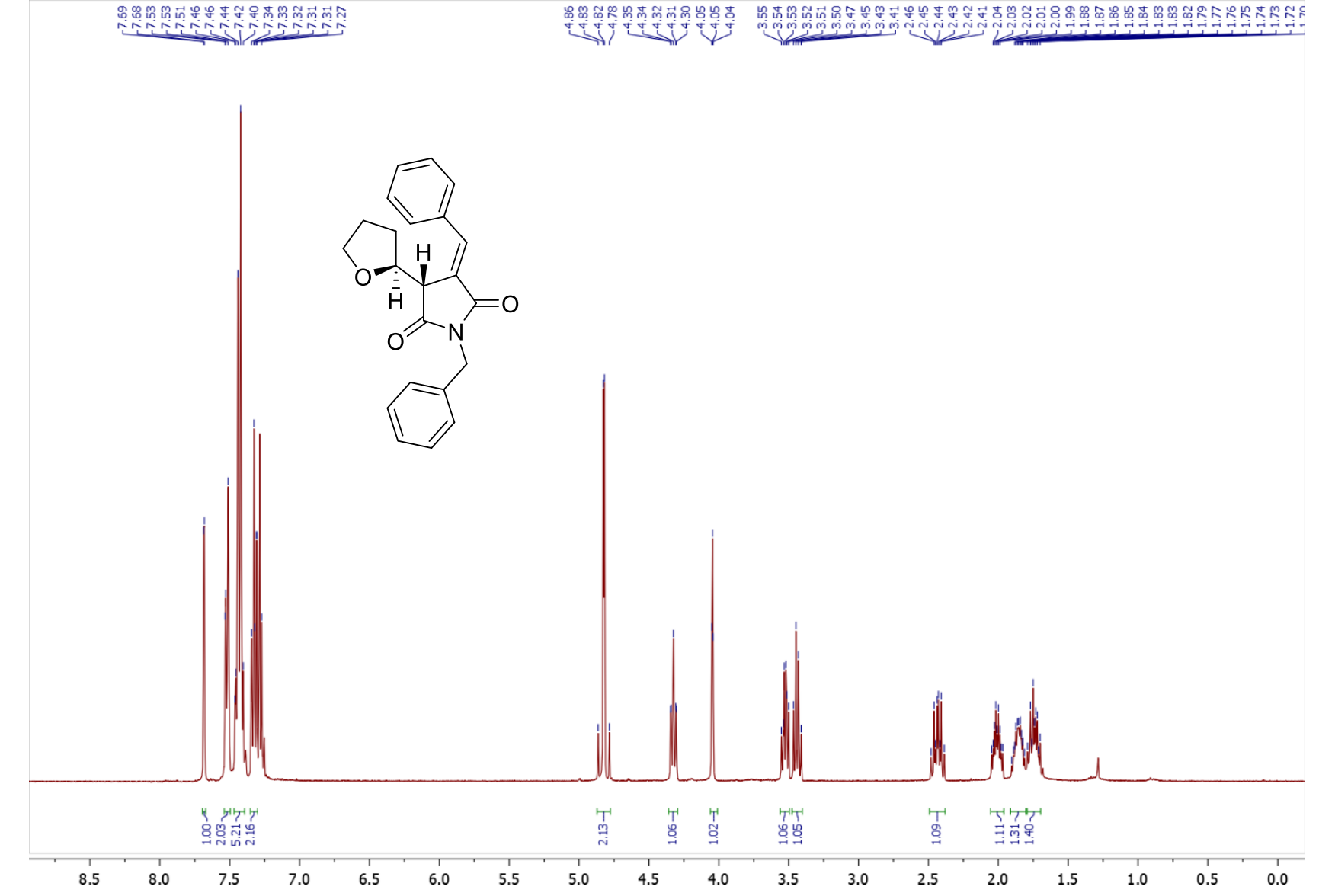

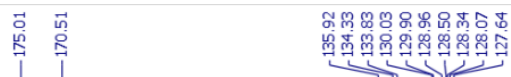

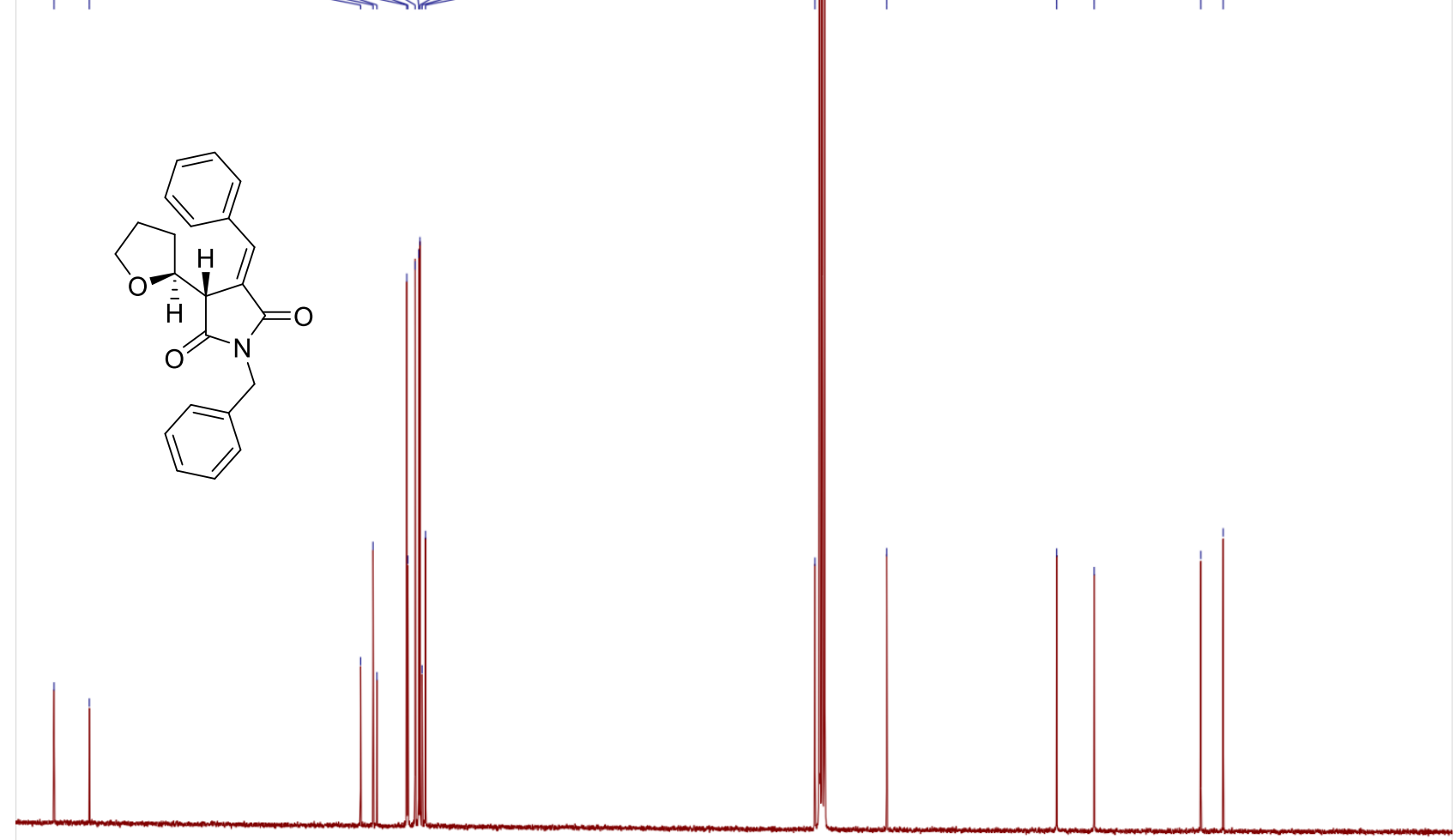

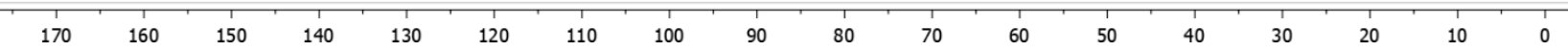


Copies of ${ }^{1} \mathrm{H}\left(400.13 \mathrm{MHz}, \mathrm{CDCl}_{3}\right)$ and ${ }^{13} \mathrm{C}\left(100.61 \mathrm{MHz}, \mathrm{CDCl}_{3}\right)$ spectra of $\mathbf{2 u}$

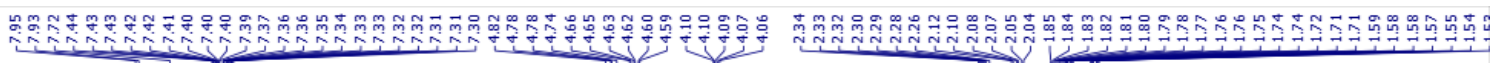

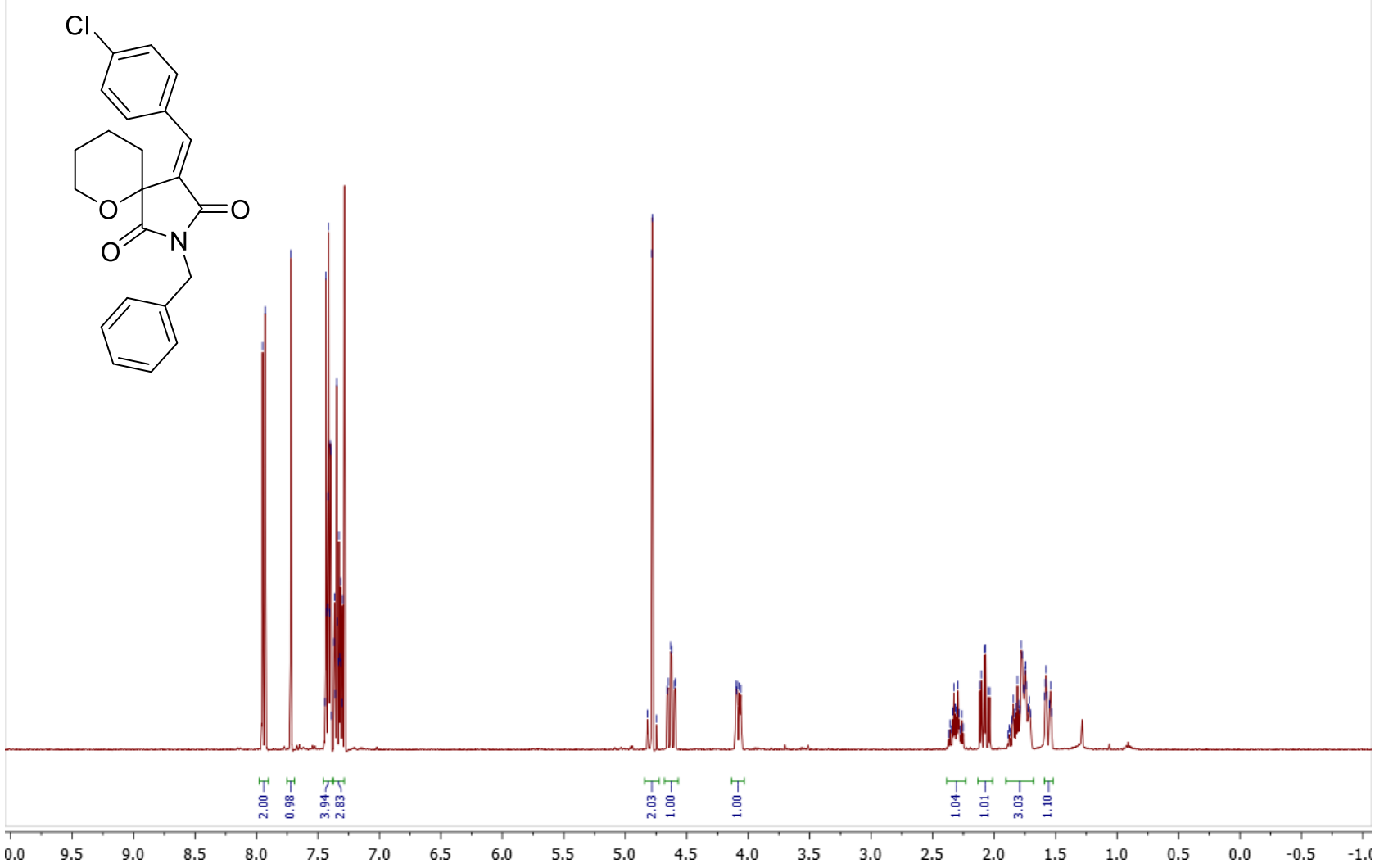

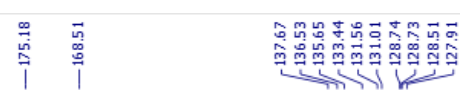

$\mathrm{Cl}$<smiles>O=C1C(=Cc2ccc(I)cc2)C(=O)C2(CCCOC2)C(=O)N1Cc1ccccc1</smiles>
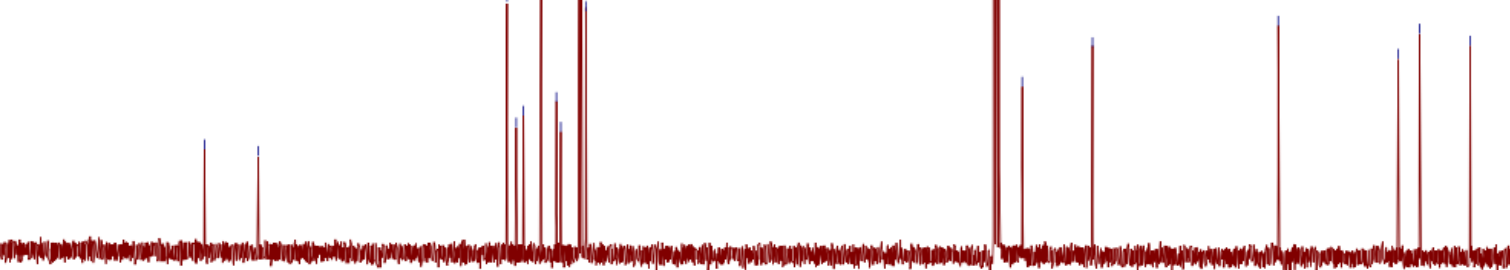
Copies of ${ }^{1} \mathrm{H}\left(400.13 \mathrm{MHz}, \mathrm{CDCl}_{3}\right)$ and ${ }^{13} \mathrm{C}\left(100.61 \mathrm{MHz}, \mathrm{CDCl}_{3}\right)$ spectra of $\mathbf{2 v}$
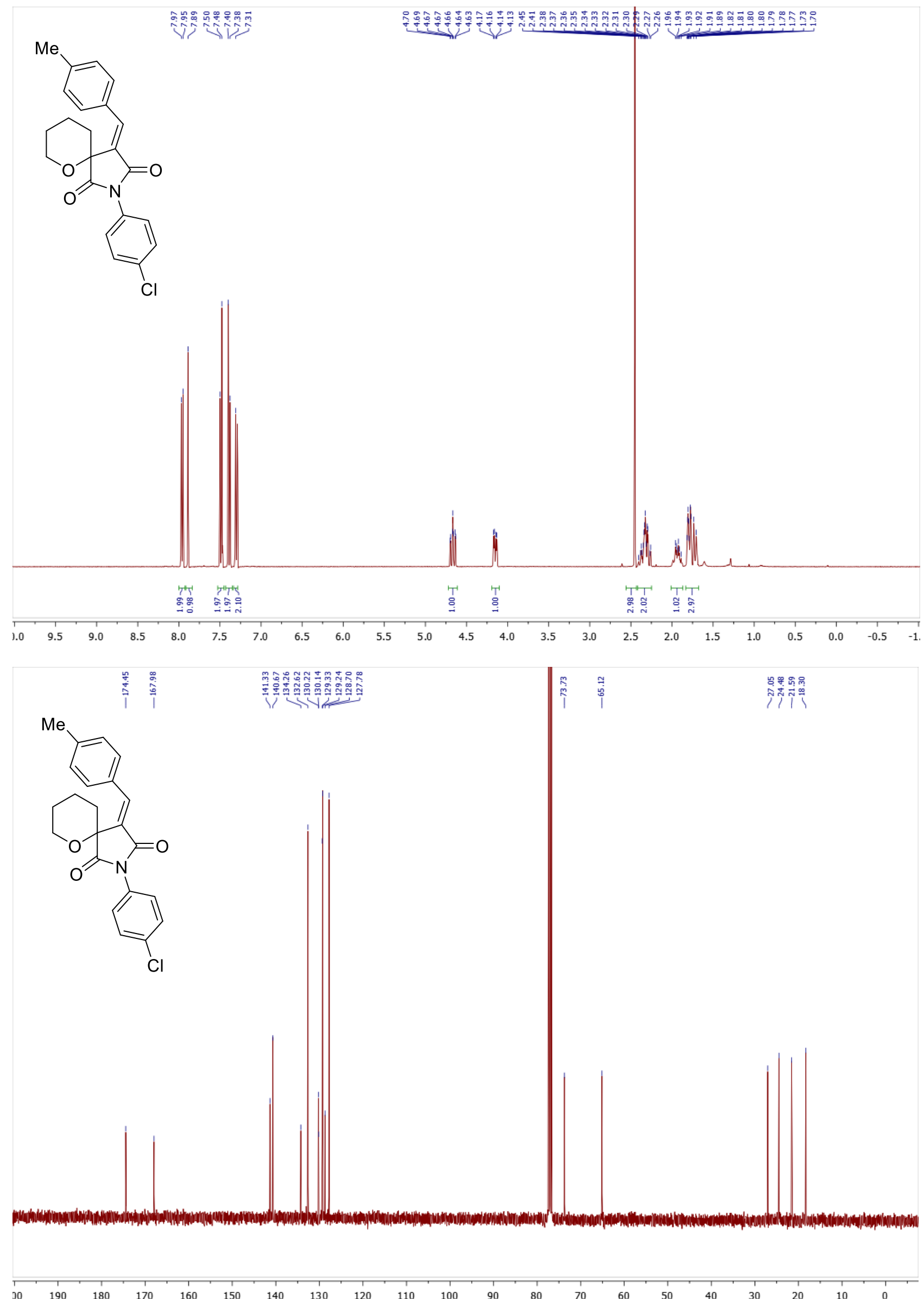
Copies of ${ }^{1} \mathrm{H}\left(400.13 \mathrm{MHz}, \mathrm{CDCl}_{3}\right)$ and ${ }^{13} \mathrm{C}\left(100.61 \mathrm{MHz}, \mathrm{CDCl}_{3}\right)$ spectra of $(\boldsymbol{R} / \mathbf{S}, \mathbf{S} / \boldsymbol{R})-\mathbf{6} \mathbf{v}^{\mathbf{m i n}}$
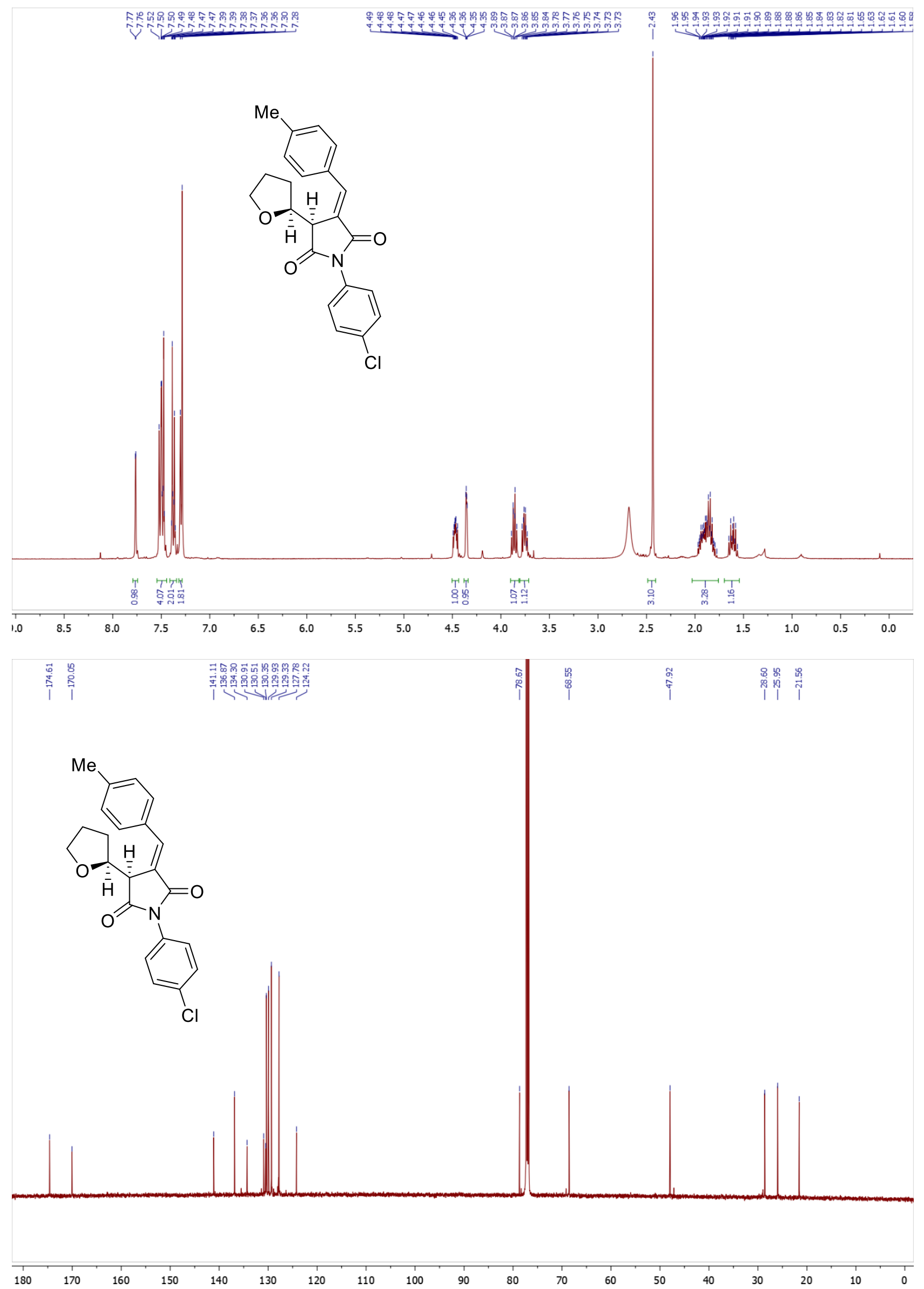
Copies of ${ }^{1} \mathrm{H}\left(400.13 \mathrm{MHz}, \mathrm{CDCl}_{3}\right)$ and ${ }^{13} \mathrm{C}\left(100.61 \mathrm{MHz}, \mathrm{CDCl}_{3}\right)$ spectra of $(\boldsymbol{S} / \boldsymbol{R}, \boldsymbol{S} / \boldsymbol{R})-\mathbf{6} \mathbf{v}^{\text {maj }}$

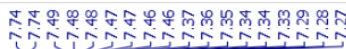

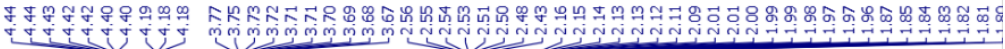

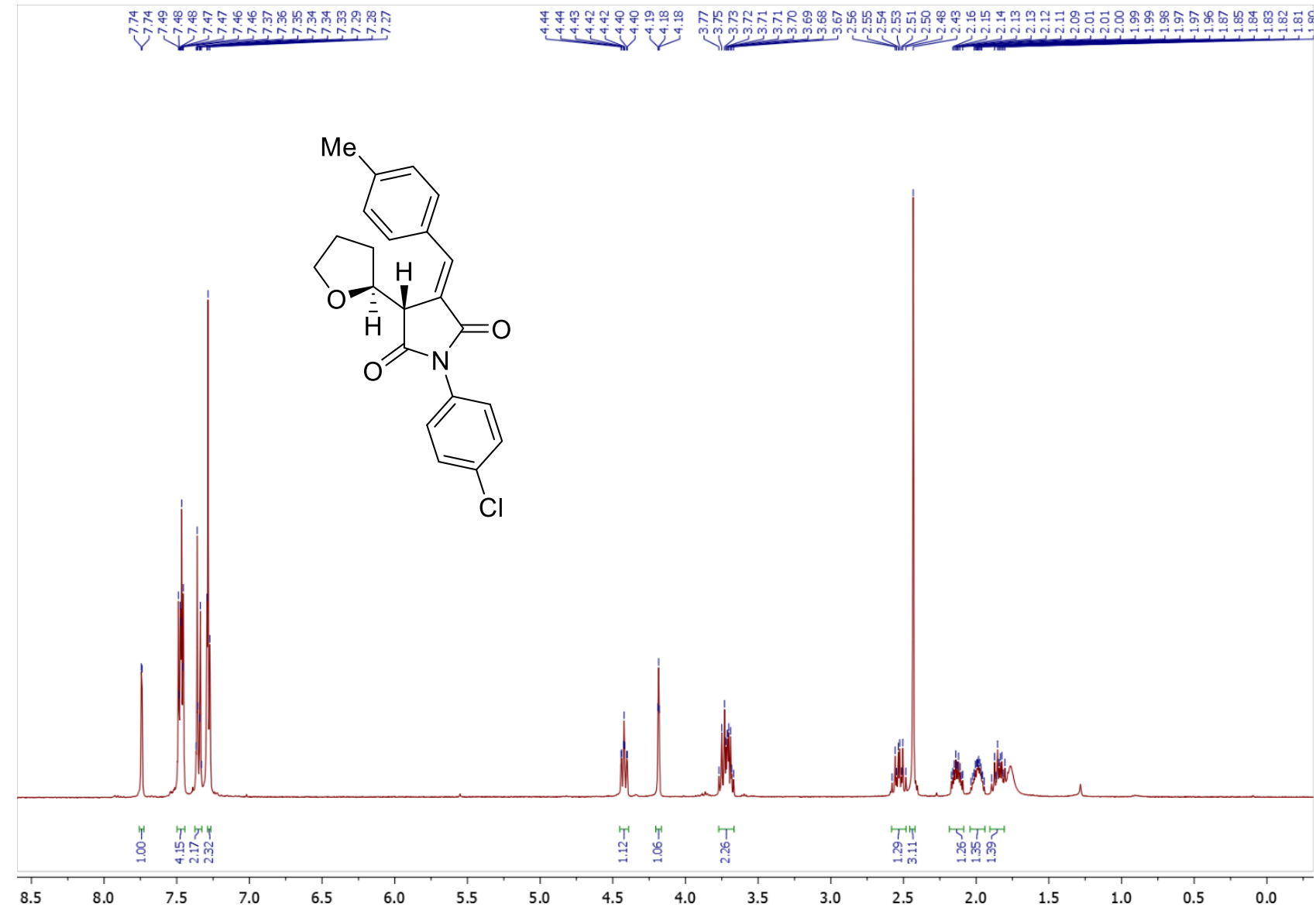

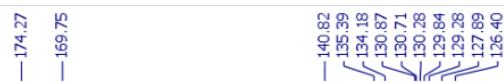<smiles></smiles>

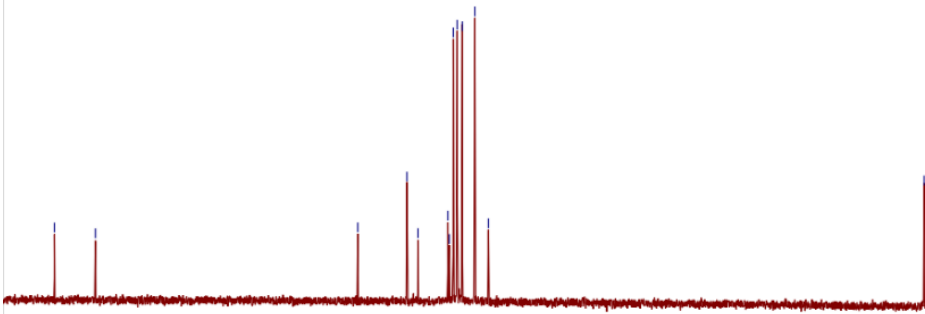

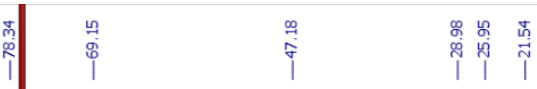


Copies of ${ }^{1} \mathrm{H}\left(400.13 \mathrm{MHz}, \mathrm{CDCl}_{3}\right)$ and ${ }^{13} \mathrm{C}\left(100.61 \mathrm{MHz}, \mathrm{CDCl}_{3}\right)$ spectra of $\mathbf{2 w}$
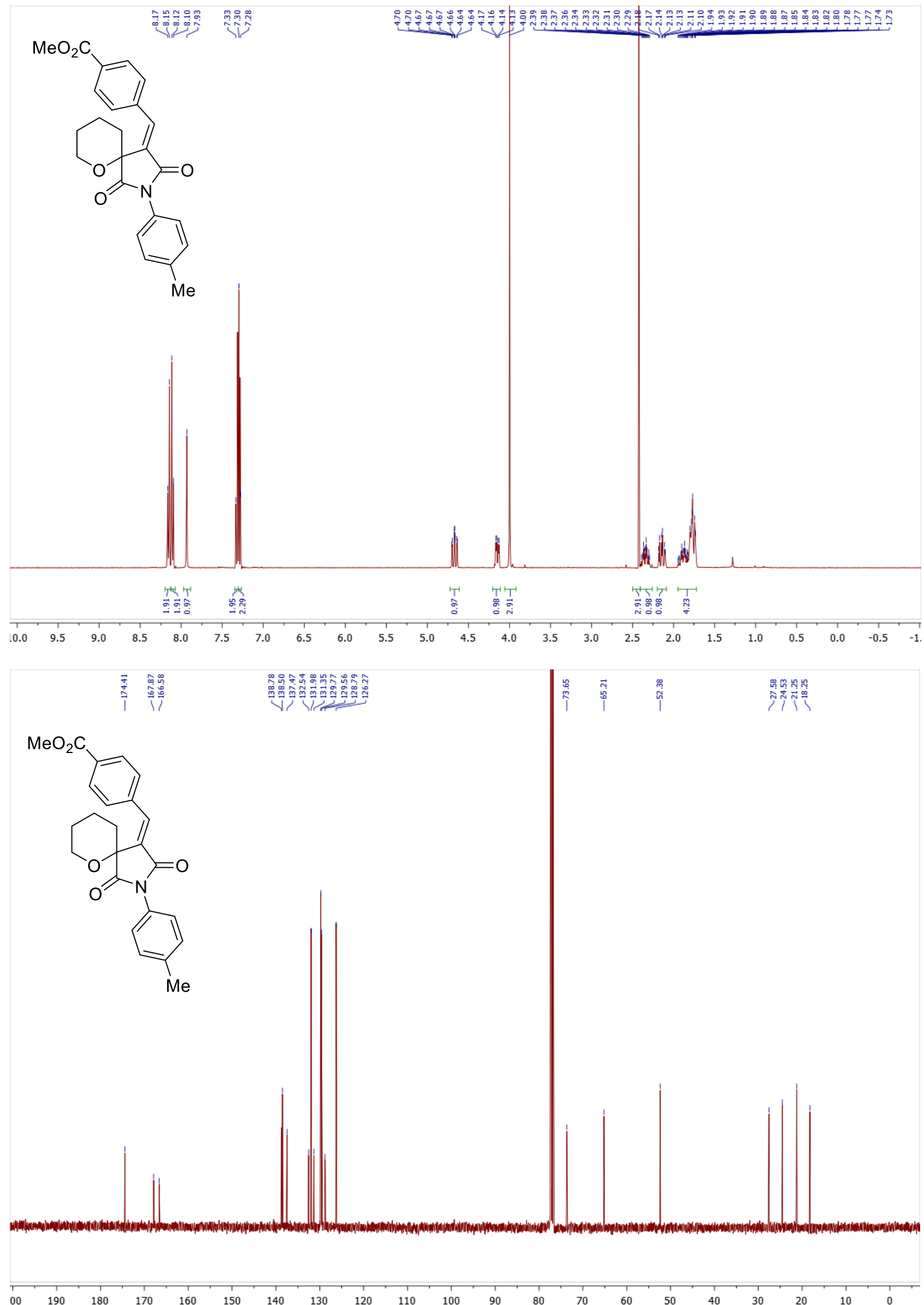
Copies of ${ }^{1} \mathrm{H}\left(400.13 \mathrm{MHz}, \mathrm{CDCl}_{3}\right)$ and ${ }^{13} \mathrm{C}\left(100.61 \mathrm{MHz}, \mathrm{CDCl}_{3}\right)$ spectra of $\mathbf{2 x}$
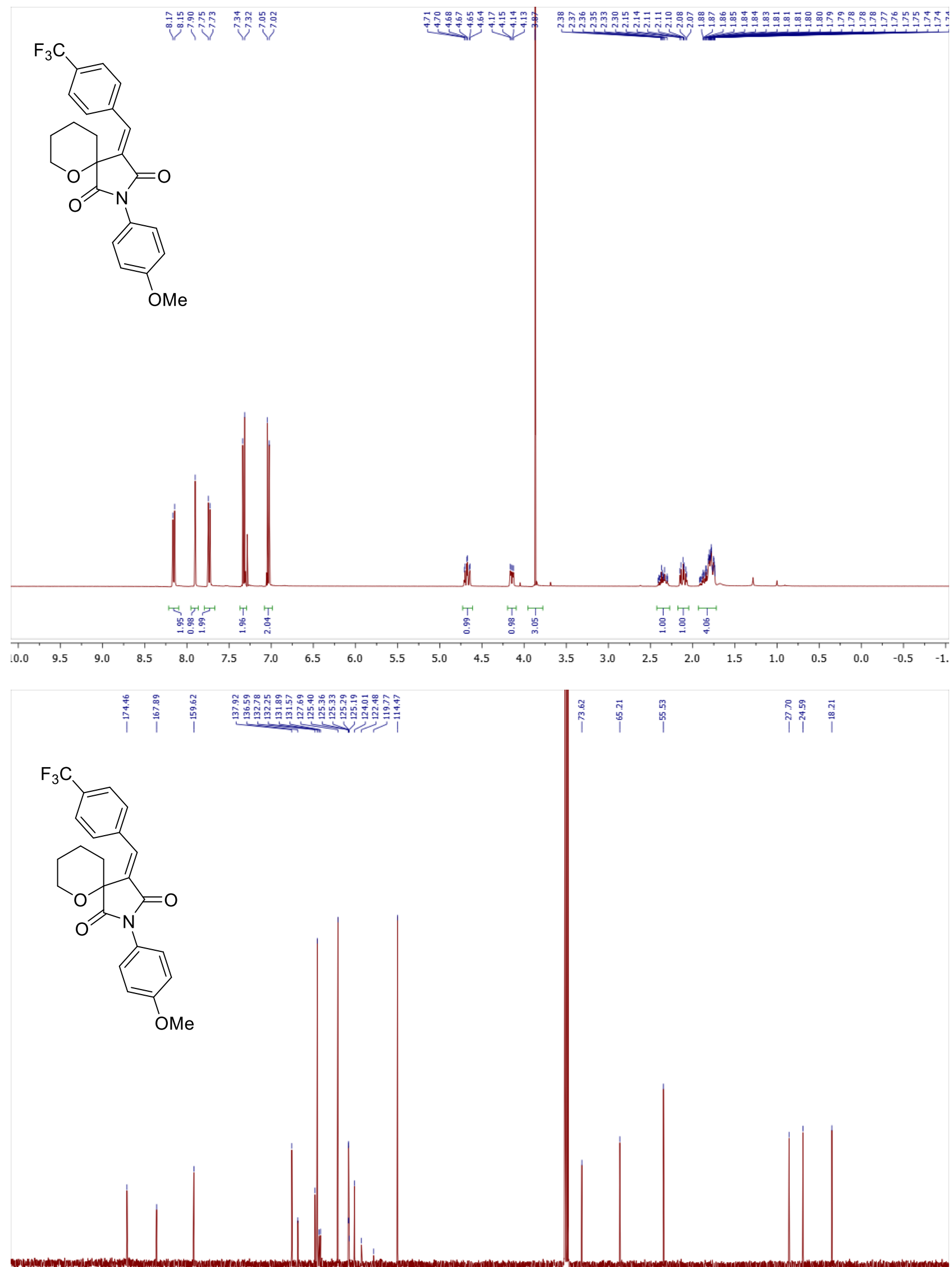

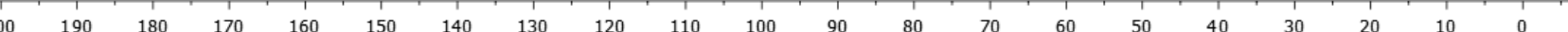


Copy of ${ }^{19} \mathrm{~F}\left(376.50 \mathrm{MHz}, \mathrm{CDCl}_{3}\right)$ spectrum of $\mathbf{2 x}$

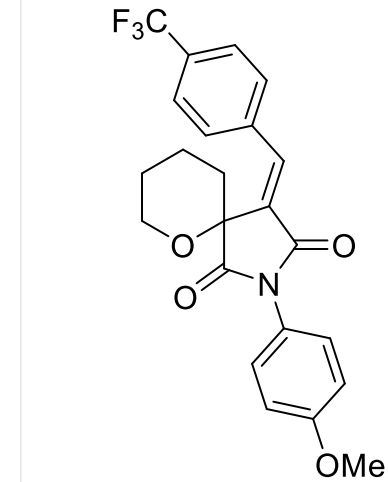

范

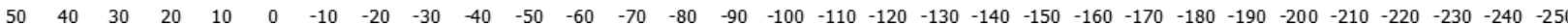


Copies of ${ }^{1} \mathrm{H}\left(400.13 \mathrm{MHz}, \mathrm{CDCl}_{3}\right)$ and ${ }^{13} \mathrm{C}\left(100.61 \mathrm{MHz}, \mathrm{CDCl}_{3}\right)$ spectra of $\mathbf{2 y}$
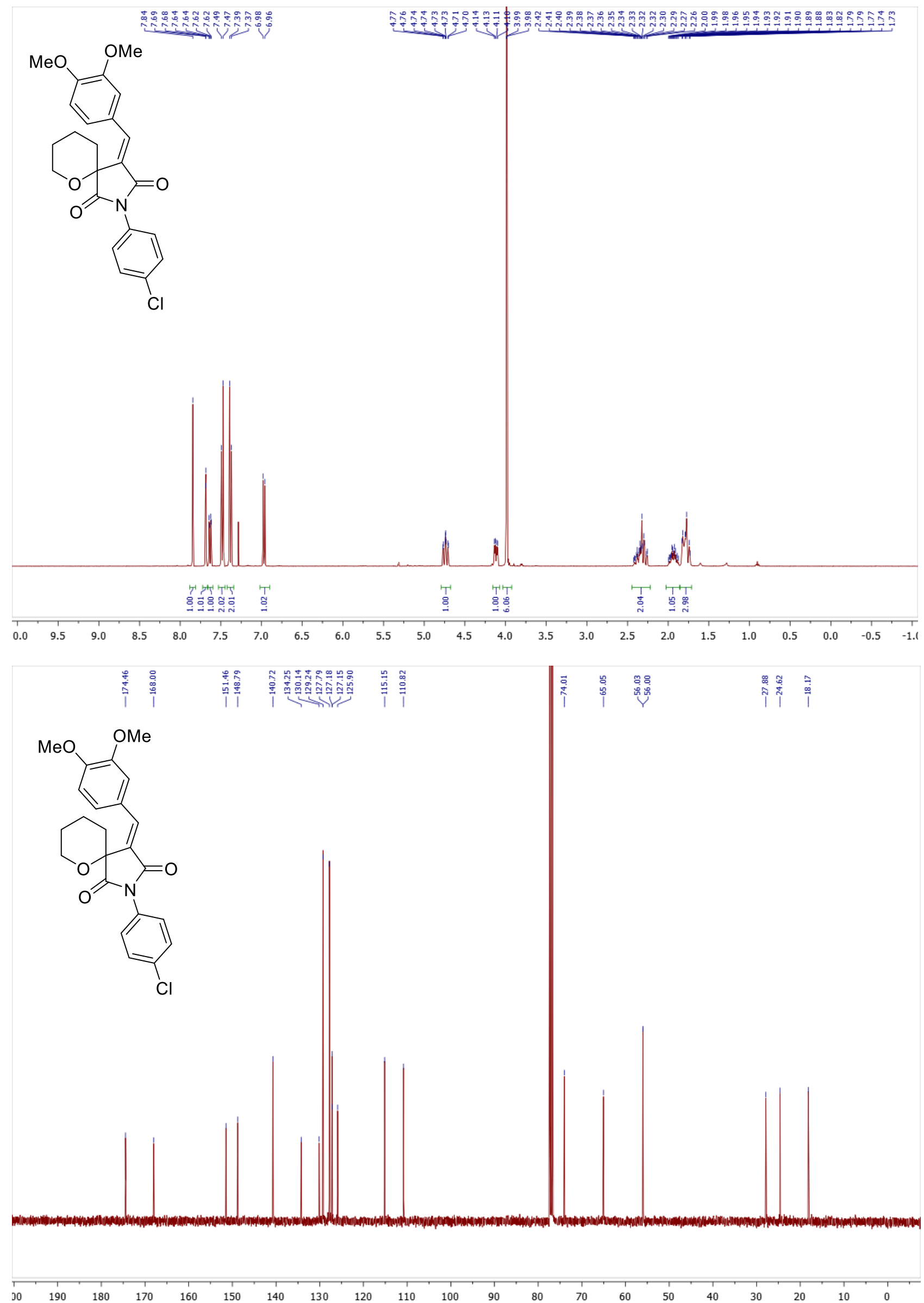
Copies of ${ }^{1} \mathrm{H}\left(400.13 \mathrm{MHz}, \mathrm{CDCl}_{3}\right)$ and ${ }^{13} \mathrm{C}\left(100.61 \mathrm{MHz}, \mathrm{CDCl}_{3}\right)$ spectra of $\mathbf{2 z}$
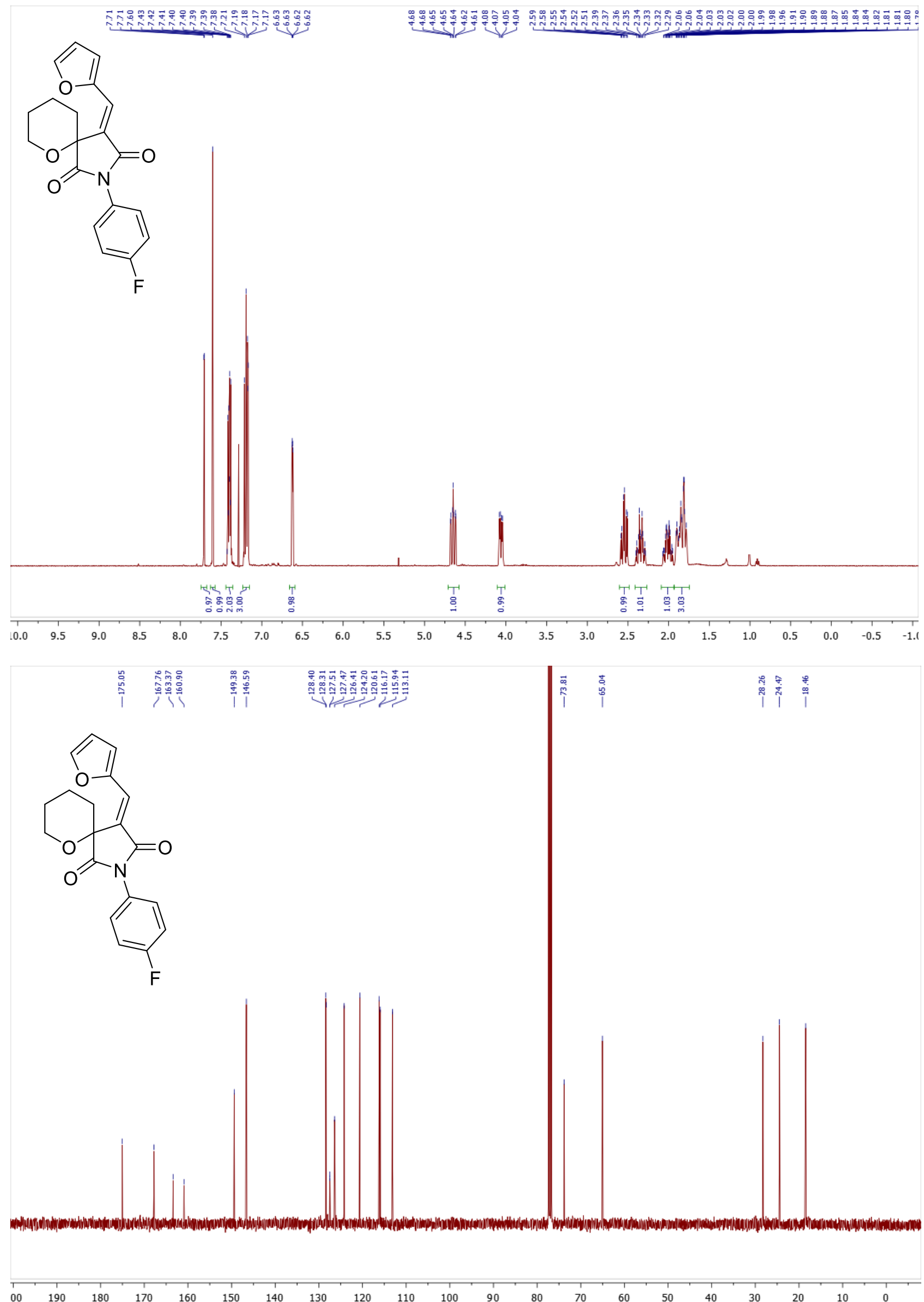
Copy of ${ }^{19} \mathrm{~F}\left(376.50 \mathrm{MHz}, \mathrm{CDCl}_{3}\right)$ spectrum of $\mathbf{2 z}$

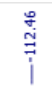<smiles>O=C1/C(=C/c2ccco2)C2(CCCCO2)C(=O)N1c1ccc(F)cc1</smiles>

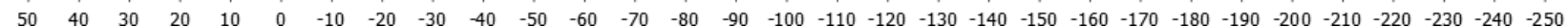


Copies of ${ }^{1} \mathrm{H}\left(400.13 \mathrm{MHz}, \mathrm{CDCl}_{3}\right)$ and ${ }^{13} \mathrm{C}\left(100.61 \mathrm{MHz}, \mathrm{CDCl}_{3}\right)$ spectra of 2aa
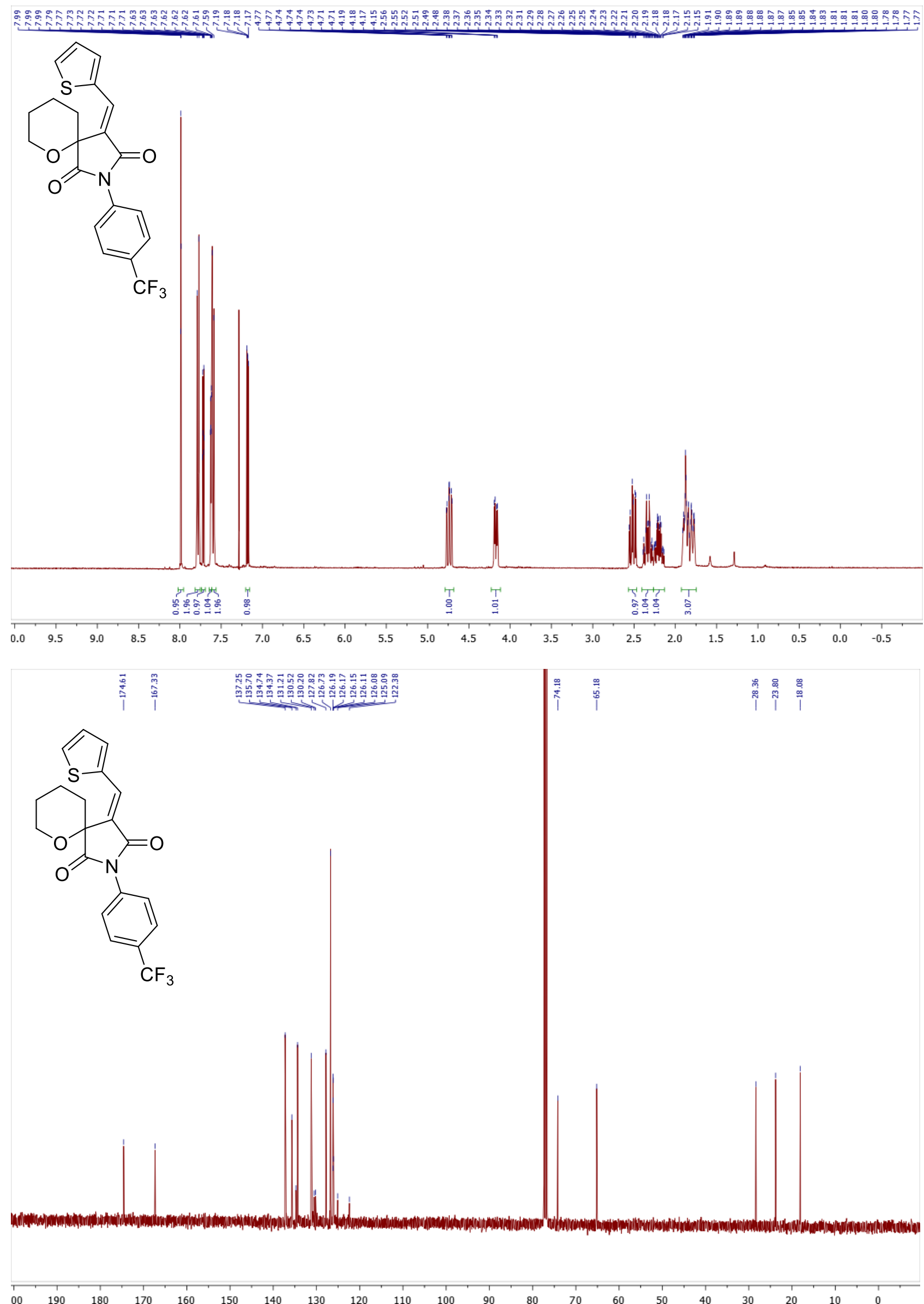
Copy of ${ }^{19} \mathrm{~F}\left(376.50 \mathrm{MHz}, \mathrm{CDCl}_{3}\right)$ spectrum of $\mathbf{2 a a}$

Nิ
în<smiles>O=C1C(=Cc2cccs2)C2(OCCCO2)C(=O)N1c1ccc(C(F)(F)F)cc1</smiles> 
Copies of ${ }^{1} \mathrm{H}\left(400.13 \mathrm{MHz}, \mathrm{CDCl}_{3}\right)$ and ${ }^{13} \mathrm{C}\left(100.61 \mathrm{MHz}, \mathrm{CDCl}_{3}\right)$ spectra of 2ab
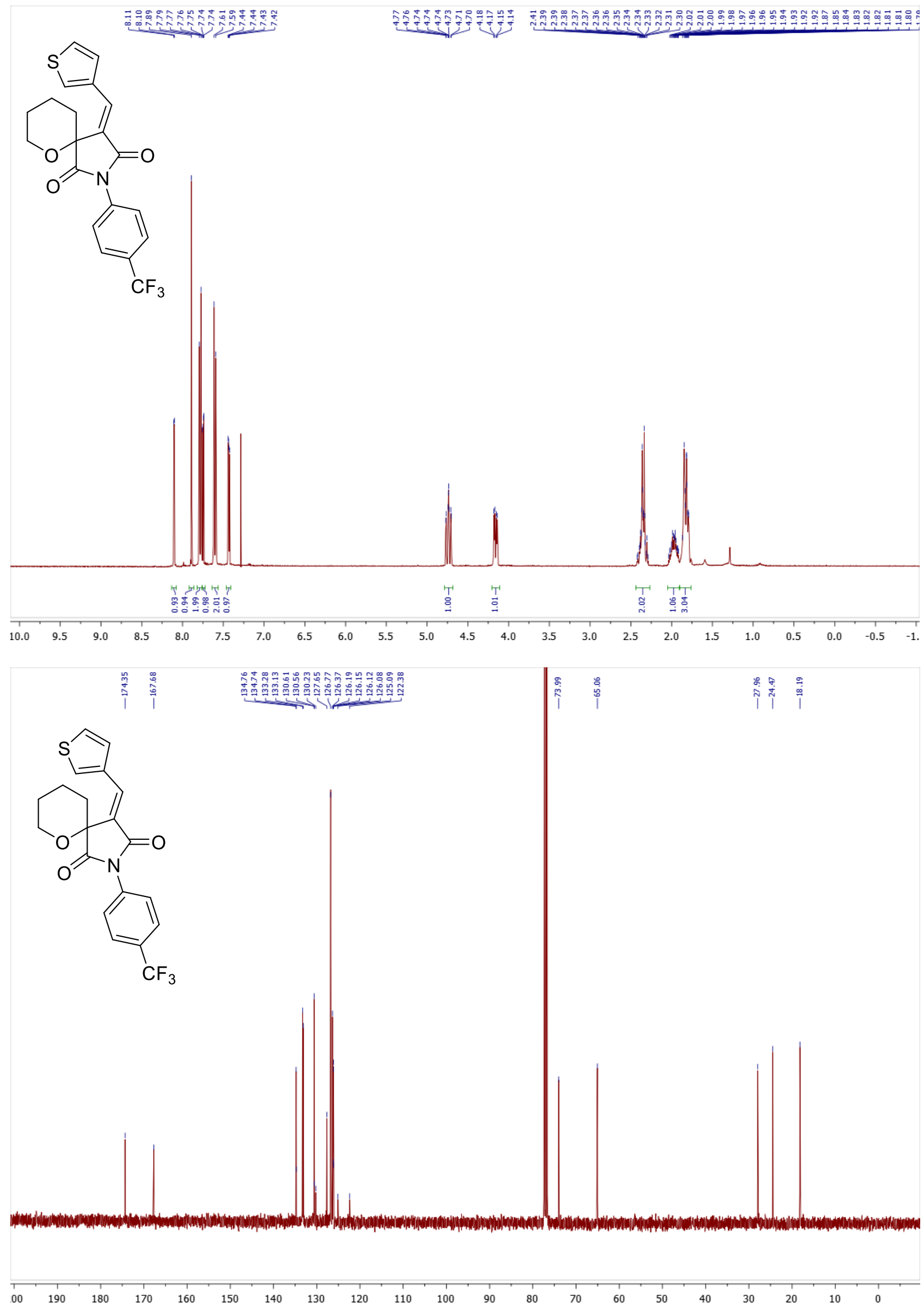
Copy of ${ }^{19} \mathrm{~F}\left(376.50 \mathrm{MHz}, \mathrm{CDCl}_{3}\right)$ spectrum of $\mathbf{2 a b}$<smiles>O=C1/C(=C/c2ccsc2)C2(CCCCO2)C(=O)N1c1ccc(C(F)(F)F)cc1</smiles> 
Copies of ${ }^{1} \mathrm{H}\left(400.13 \mathrm{MHz}, \mathrm{CDCl}_{3}\right)$ and ${ }^{13} \mathrm{C}\left(100.61 \mathrm{MHz}, \mathrm{CDCl}_{3}\right)$ spectra of $(\boldsymbol{S} / \boldsymbol{R}, \boldsymbol{S} / \boldsymbol{R})-\mathbf{6} \mathbf{b}^{\text {maj }}$
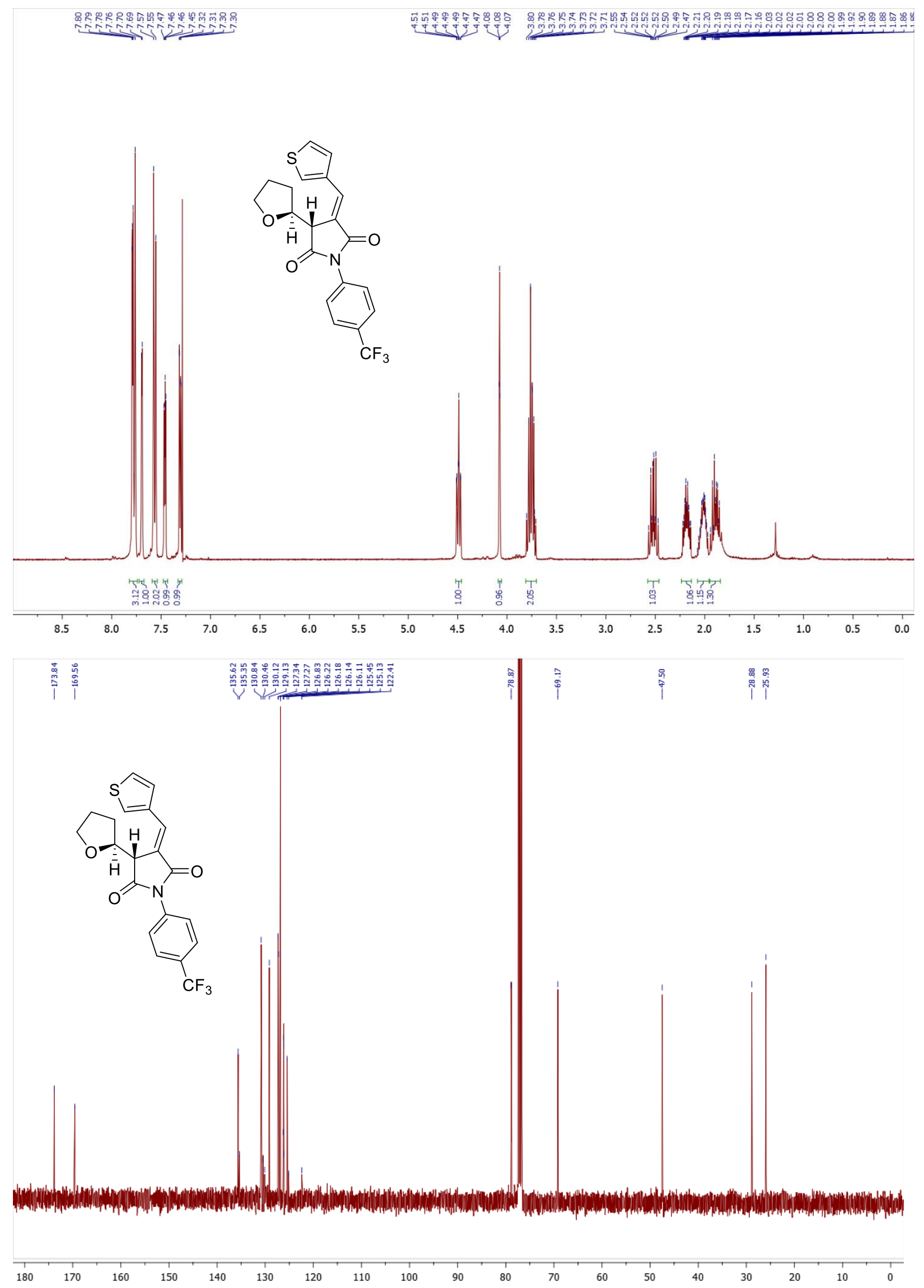
Copy of ${ }^{19} \mathrm{~F}\left(376.50 \mathrm{MHz}, \mathrm{CDCl}_{3}\right)$ spectrum of $(\boldsymbol{S} / \boldsymbol{R}, \mathbf{S} / \boldsymbol{R})-\mathbf{6} \mathbf{a} \mathbf{b}^{\text {maj }}$

iัฺ<smiles>O=C1C(=O)[C@@H]2OCCO[C@@H]2C1=Cc1ccsc1</smiles>

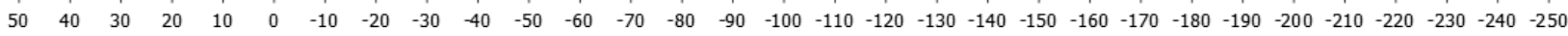


Copies of ${ }^{1} \mathrm{H}\left(400.13 \mathrm{MHz}, \mathrm{CDCl}_{3}\right)$ and ${ }^{13} \mathrm{C}\left(100.61 \mathrm{MHz}, \mathrm{CDCl}_{3}\right)$ spectra of $\mathbf{2 a c}$

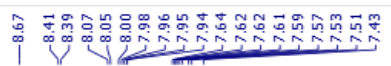

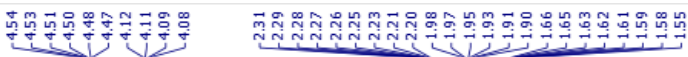
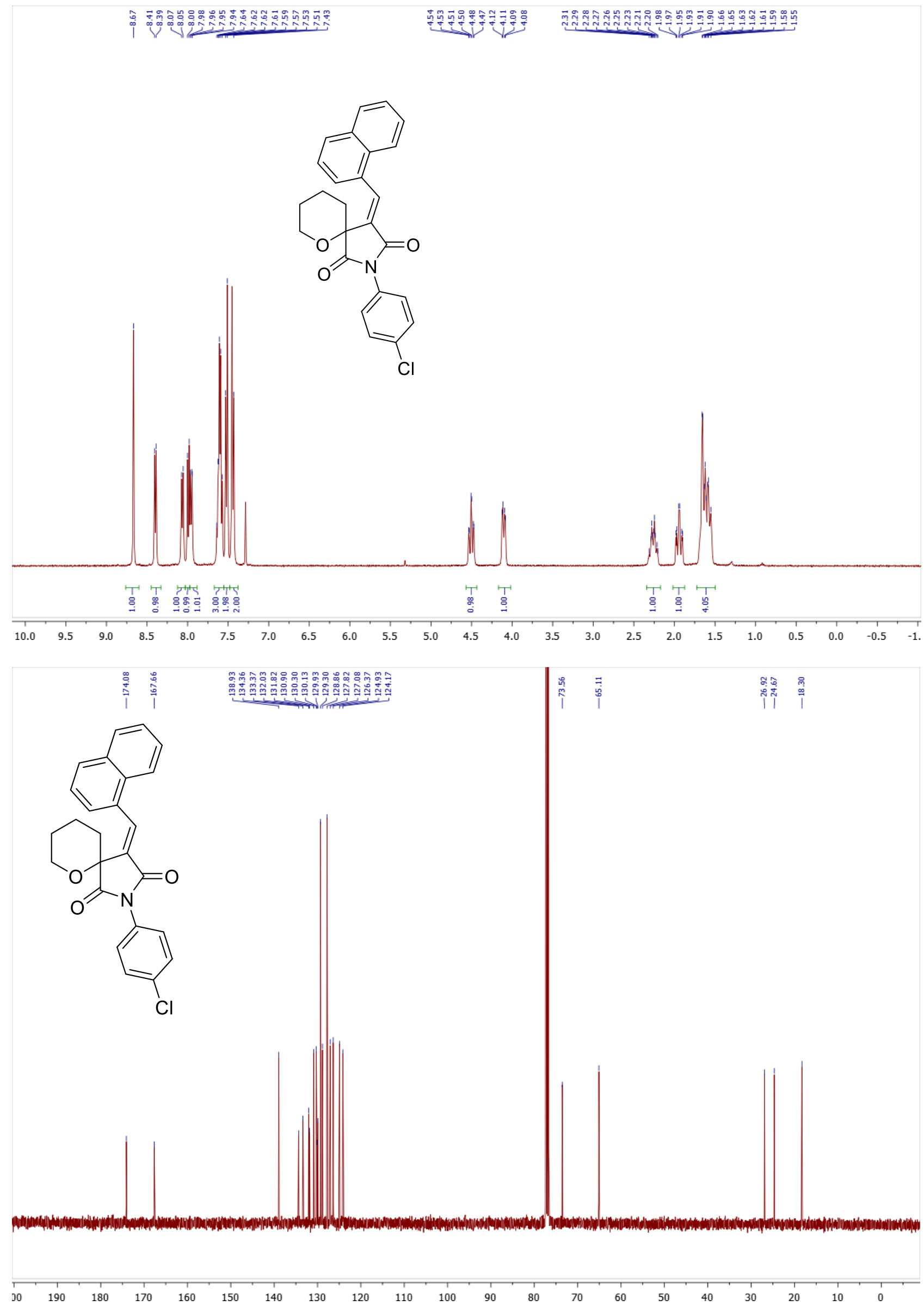
Copies of ${ }^{1} \mathrm{H}\left(400.13 \mathrm{MHz}, \mathrm{CDCl}_{3}\right)$ and ${ }^{13} \mathrm{C}\left(100.61 \mathrm{MHz}, \mathrm{CDCl}_{3}\right)$ spectra of $2 \mathbf{a d}$
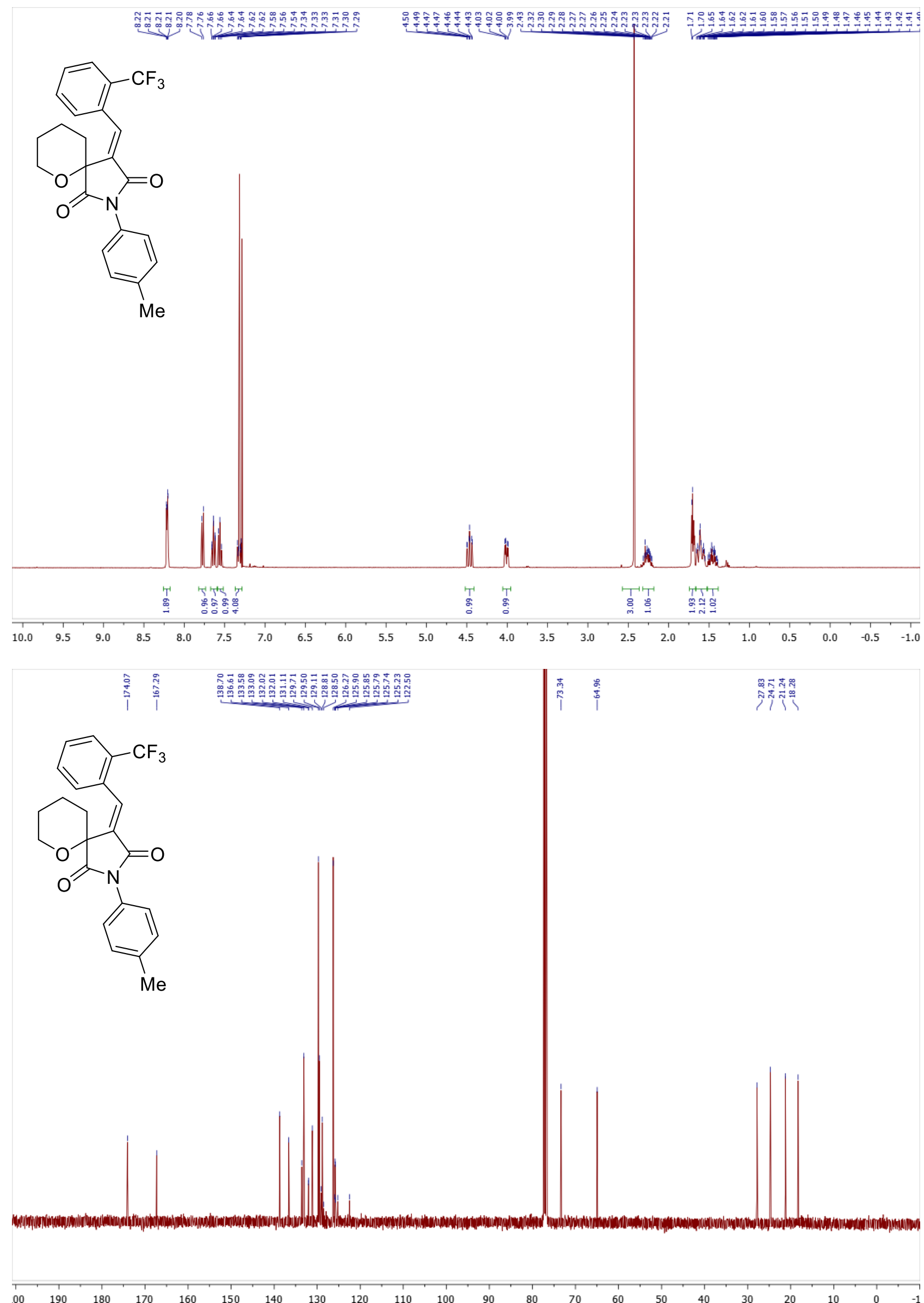
Copy of ${ }^{19} \mathrm{~F}\left(376.50 \mathrm{MHz}, \mathrm{CDCl}_{3}\right)$ spectrum of $\mathbf{2 a d}$

ìn<smiles>Cc1ccc(N2OC3(CCCCO3)/C(=C\c3ccccc3C(F)(F)F)C2=O)cc1</smiles>

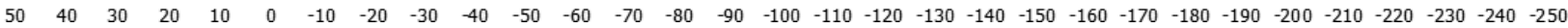


Copies of ${ }^{1} \mathrm{H}\left(400.13 \mathrm{MHz}, \mathrm{CDCl}_{3}\right)$ and ${ }^{13} \mathrm{C}\left(100.61 \mathrm{MHz}, \mathrm{CDCl}_{3}\right)$ spectra of $\mathbf{1 0 g}$
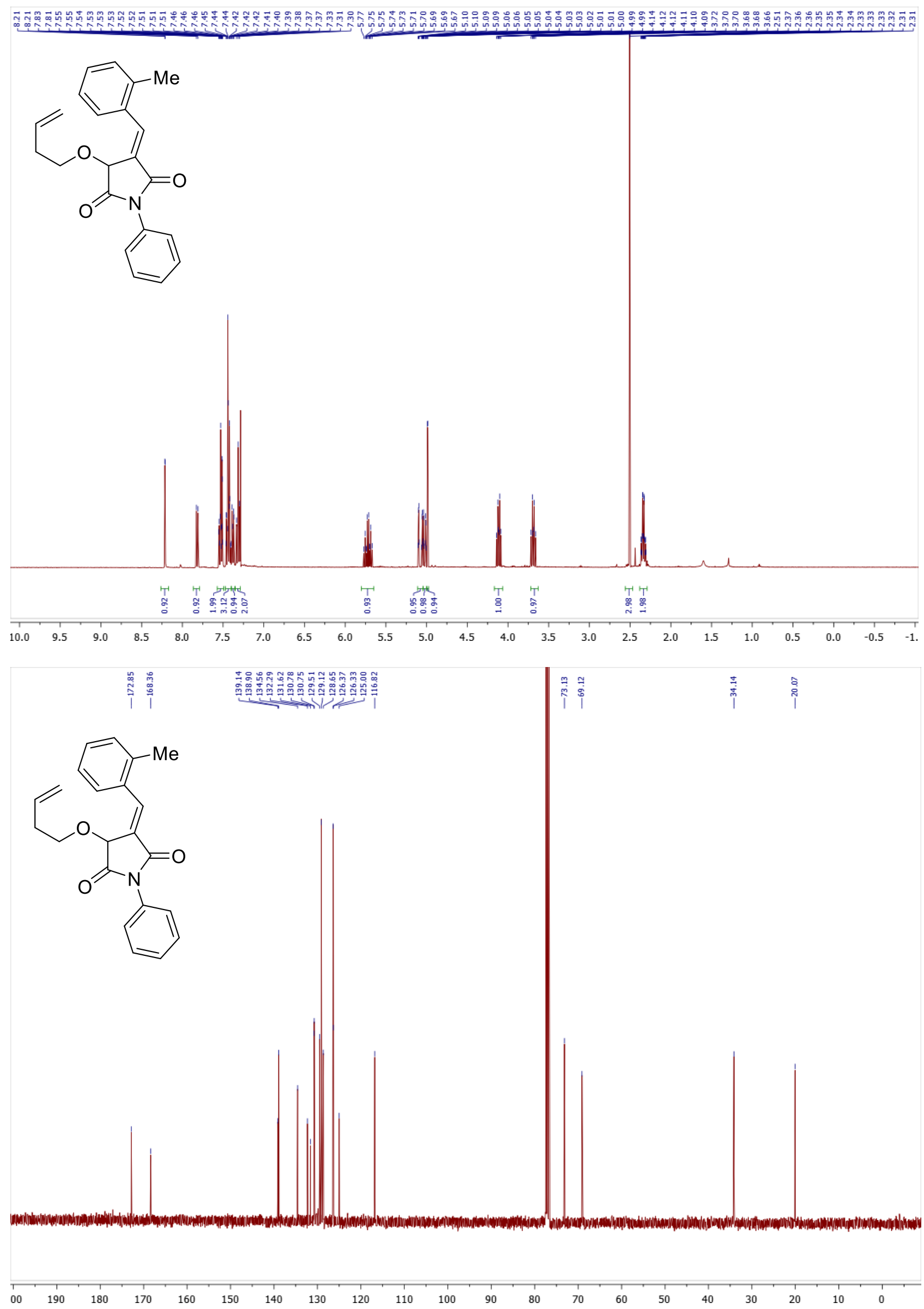
Copies of ${ }^{1} \mathrm{H}\left(400.13 \mathrm{MHz}, \mathrm{CDCl}_{3}\right)$ and ${ }^{13} \mathrm{C}\left(100.61 \mathrm{MHz}, \mathrm{CDCl}_{3}\right)$ spectra of $(\boldsymbol{R} / \boldsymbol{S}, \boldsymbol{R} / \boldsymbol{S})-\mathbf{1 7} \mathbf{a}$

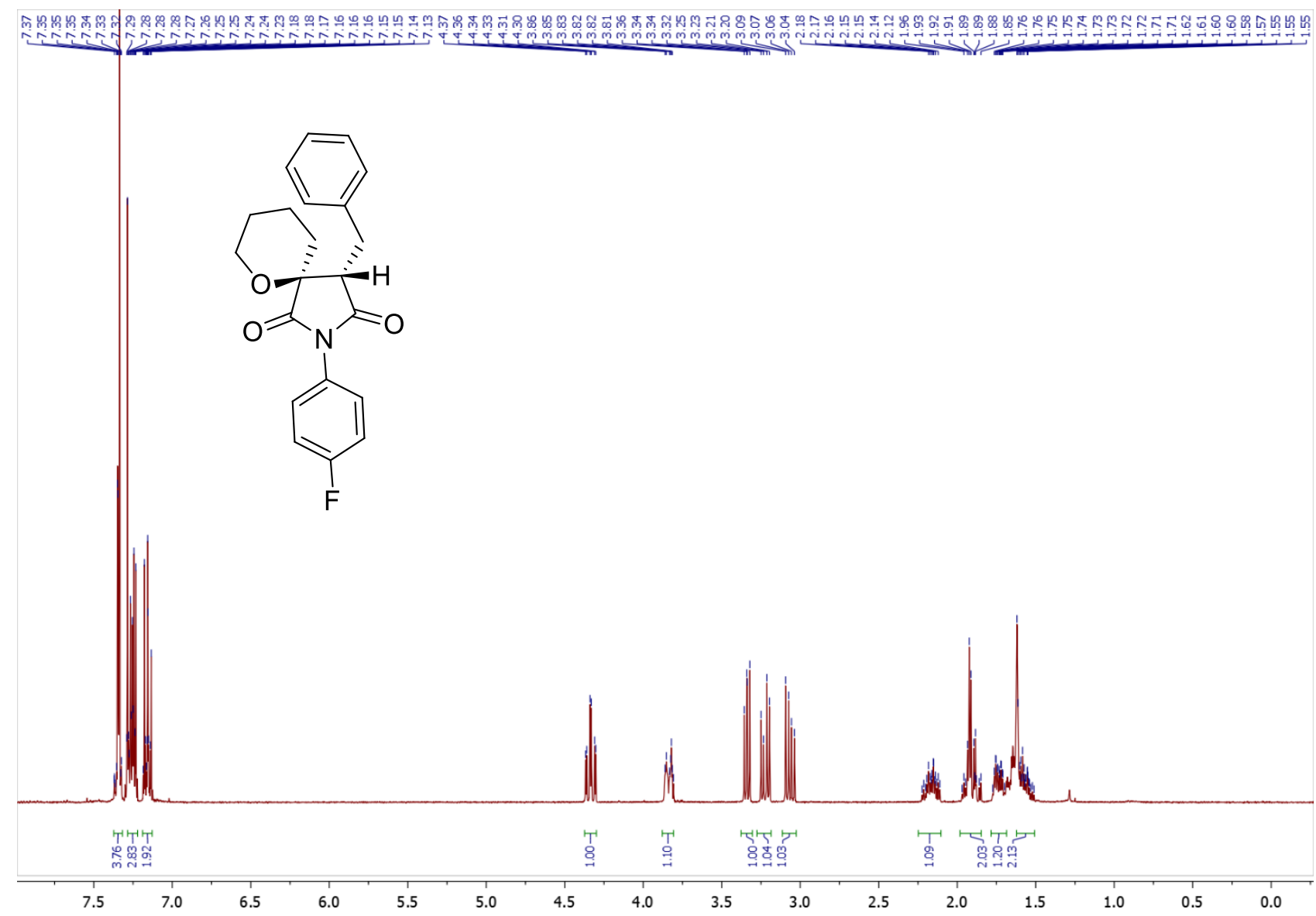

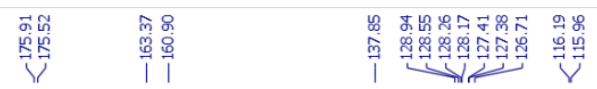

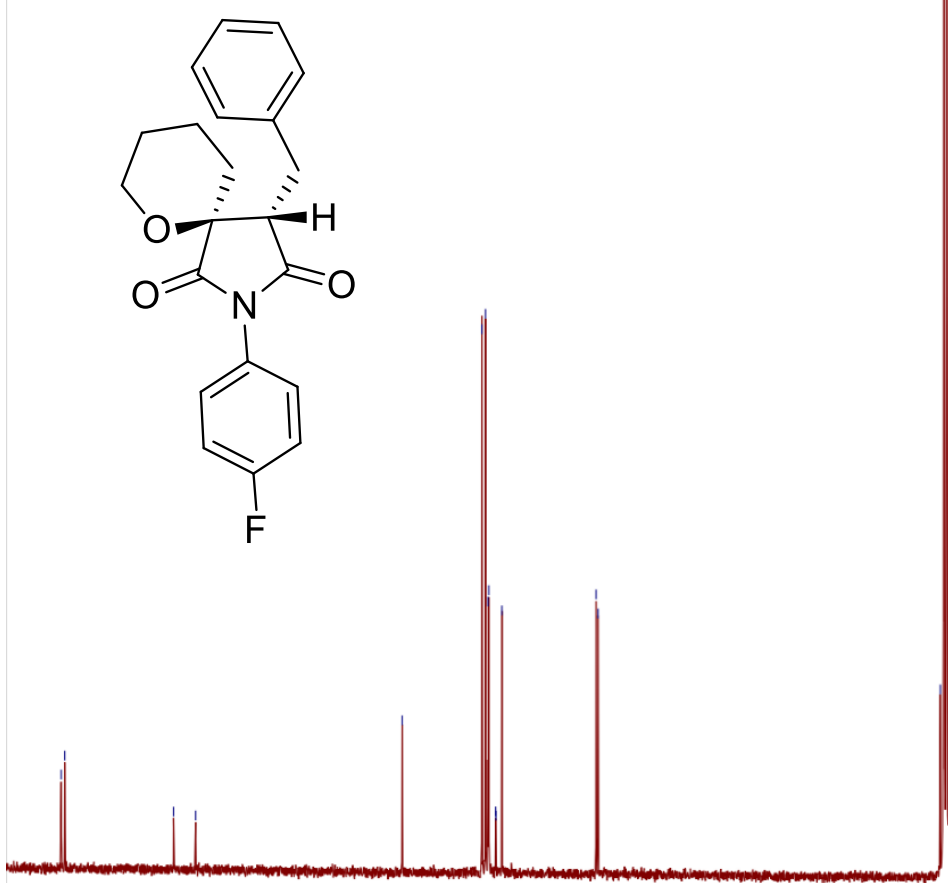

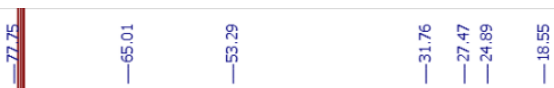


Copy of ${ }^{19} \mathrm{~F}\left(376.50 \mathrm{MHz}, \mathrm{CDCl}_{3}\right)$ spectrum of $(\boldsymbol{R} / \boldsymbol{S}, \boldsymbol{R} / \boldsymbol{S})-\mathbf{1 7} \mathbf{a}$<smiles>Cc1ccccc1C1C(=O)N(c2ccc(F)cc2)C(=O)C12CCCOC2</smiles>

NOESY (400.13 MHz, $\left.\mathrm{CDCl}_{3}\right)$ spectrum of compound $(\boldsymbol{R} / \mathbf{S}, \boldsymbol{R} / \boldsymbol{S})-\mathbf{1 7} \mathbf{a}$

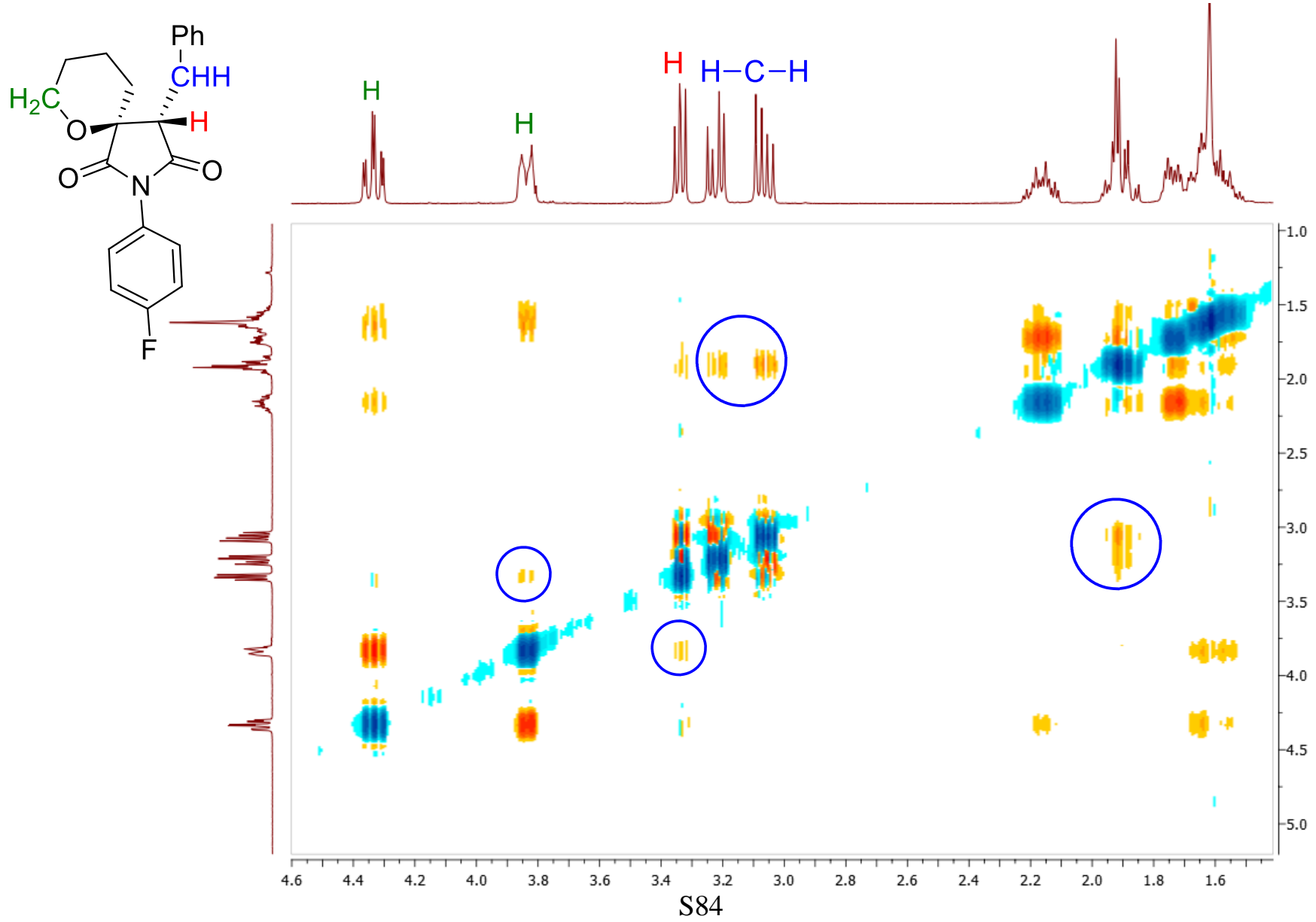


Copies of ${ }^{1} \mathrm{H}\left(400.13 \mathrm{MHz}, \mathrm{CDCl}_{3}\right)$ and ${ }^{13} \mathrm{C}\left(100.61 \mathrm{MHz}, \mathrm{CDCl}_{3}\right)$ spectra of $(\boldsymbol{R} / \boldsymbol{S}, \boldsymbol{S} / \boldsymbol{R})-\mathbf{1 7 a}$

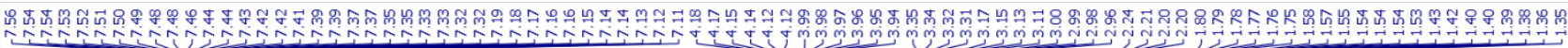
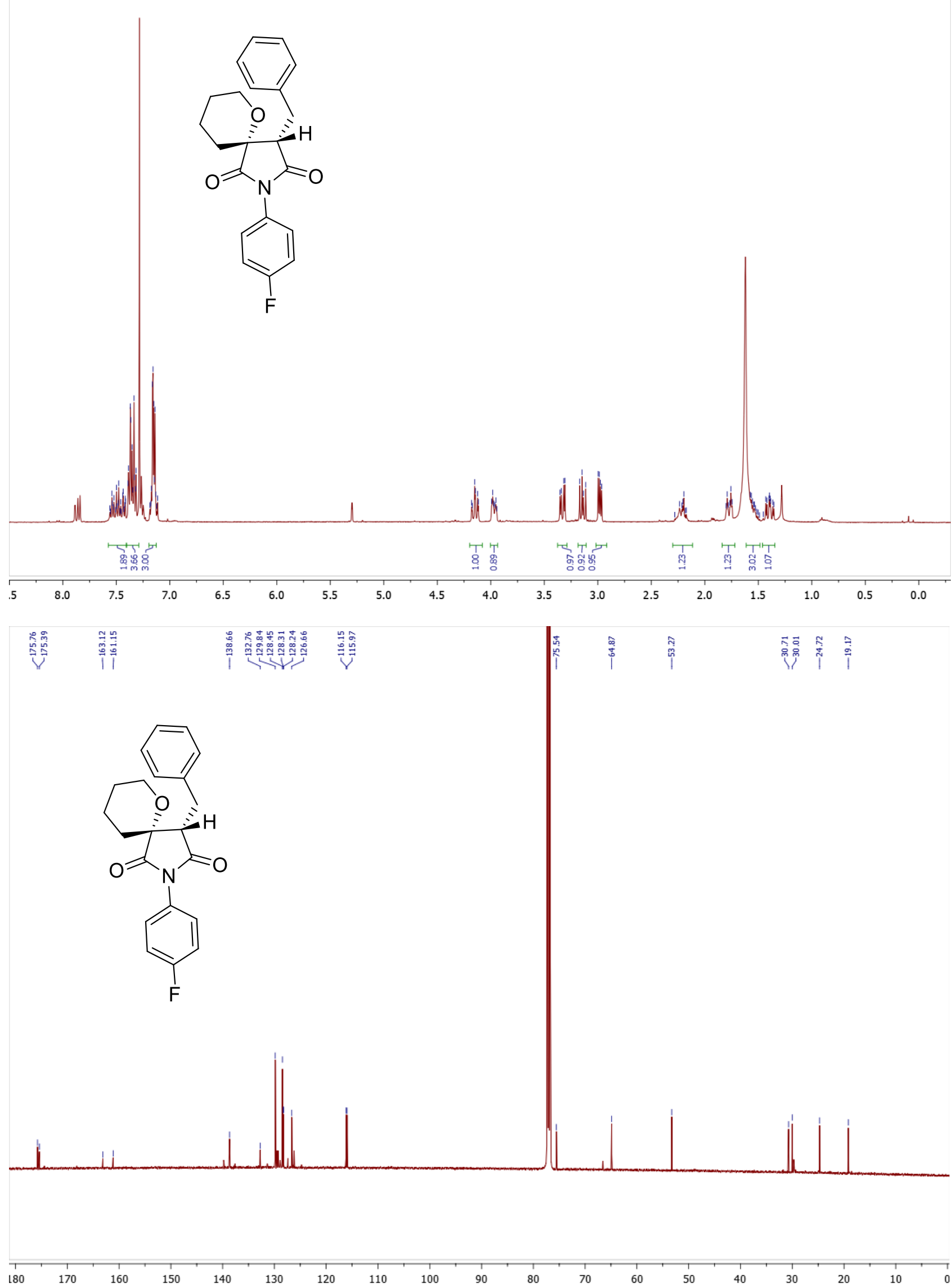
Copy of ${ }^{19} \mathrm{~F}\left(376.50 \mathrm{MHz}, \mathrm{CDCl}_{3}\right)$ spectrum of $(\boldsymbol{R} / \boldsymbol{S}, \mathbf{S} / \boldsymbol{R})-\mathbf{1 7} \mathbf{a}$<smiles>O=C1[C@H](c2ccccc2)[C@]2(CCCC[C@H]2O)C(=O)N1c1ccc(F)cc1</smiles>

NOESY $\left(400.13 \mathrm{MHz}, \mathrm{CDCl}_{3}\right)$ spectrum of compound $(\boldsymbol{R} / \boldsymbol{S}, \boldsymbol{S} / \boldsymbol{R})$-17a

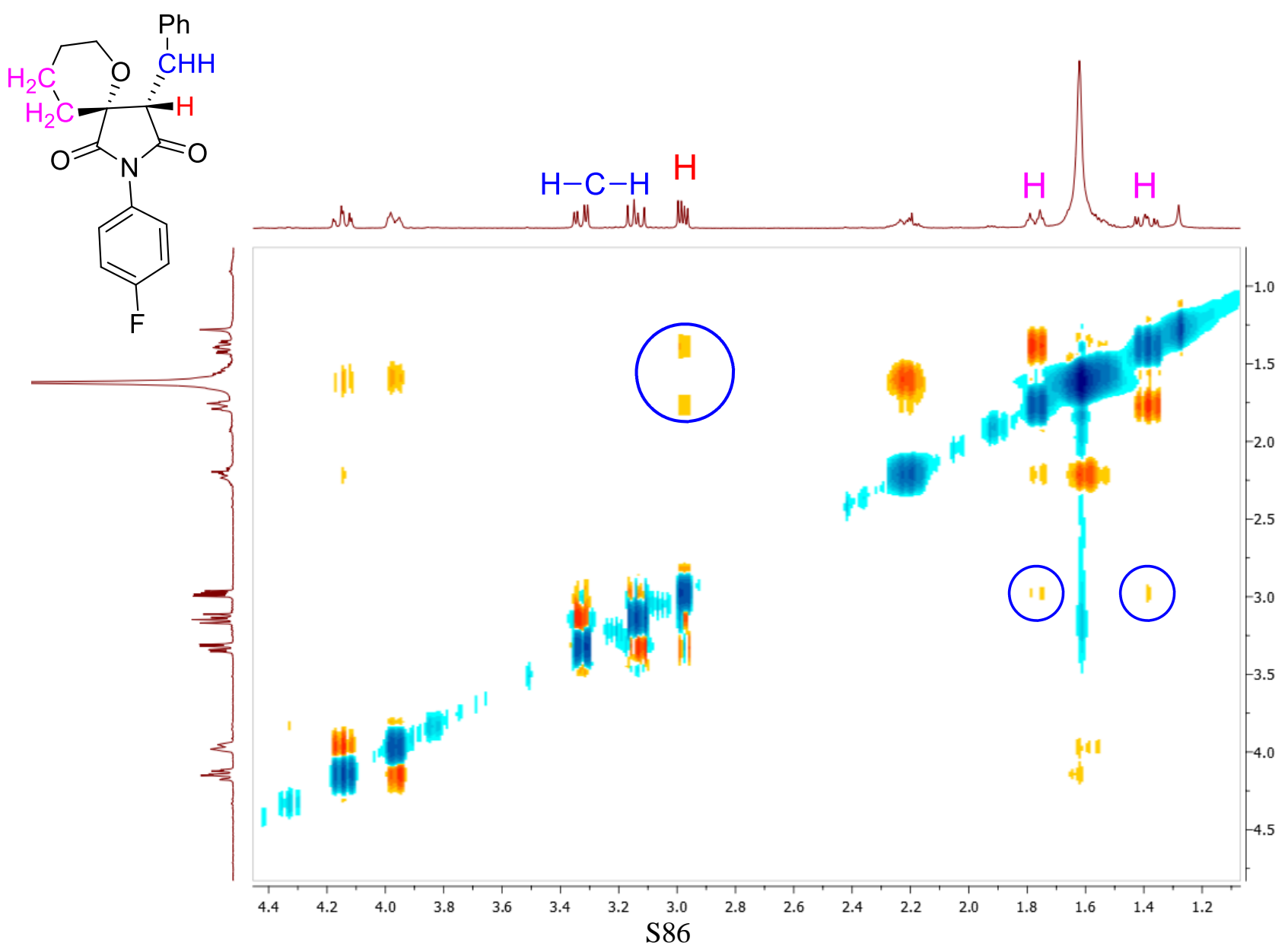


Copies of ${ }^{1} \mathrm{H}\left(400.13 \mathrm{MHz}, \mathrm{CDCl}_{3}\right)$ and ${ }^{13} \mathrm{C}\left(100.61 \mathrm{MHz}, \mathrm{CDCl}_{3}\right)$ spectra of $(\boldsymbol{R} / \boldsymbol{S}, \boldsymbol{R} / \boldsymbol{S})-\mathbf{1 7} \mathbf{g}$
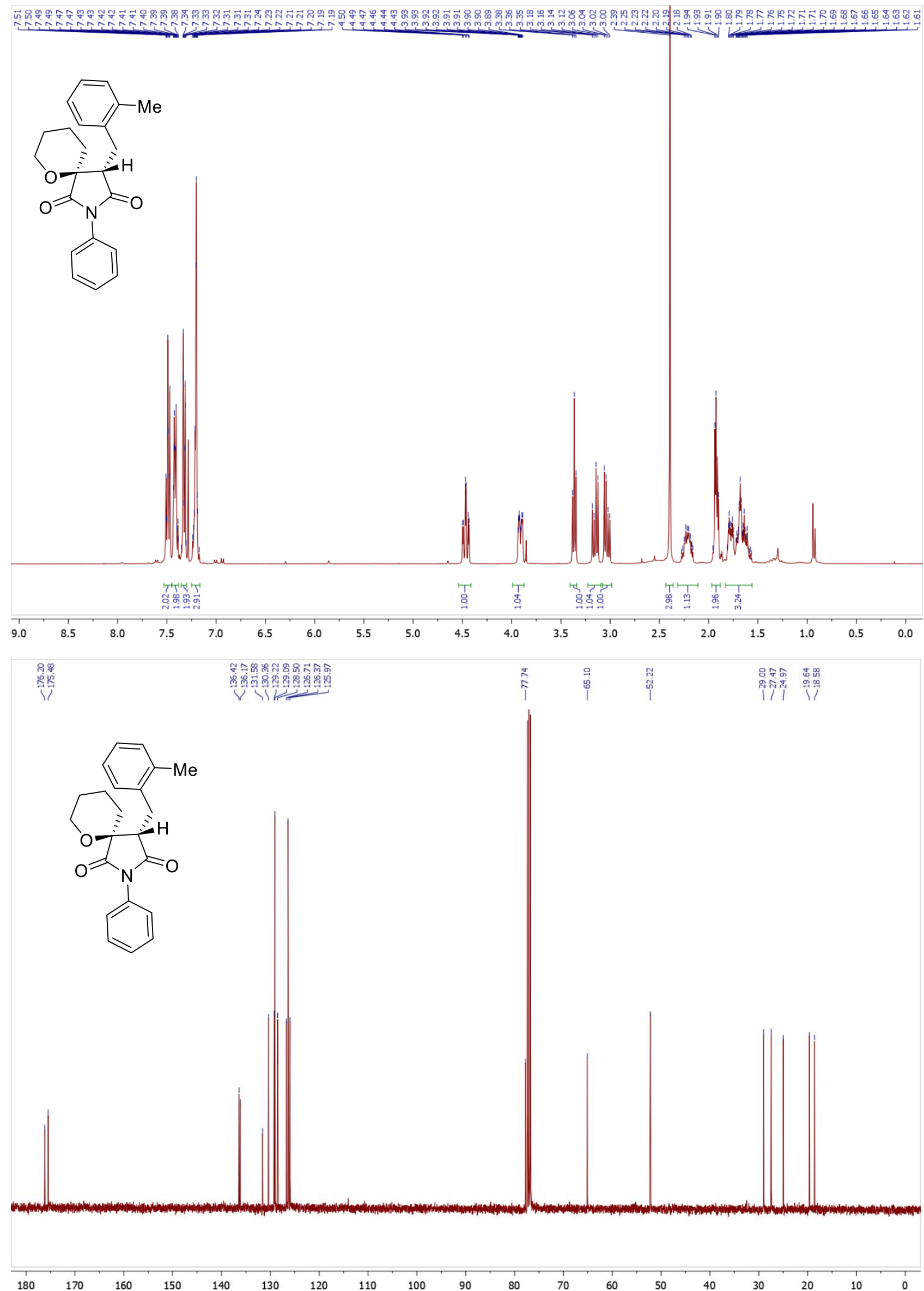
NOESY (400.13 MHz, $\left.\mathrm{CDCl}_{3}\right)$ spectrum of compound $(\boldsymbol{R} / \boldsymbol{S}, \boldsymbol{R} / \boldsymbol{S}) \mathbf{- 1 7} \mathbf{g}$

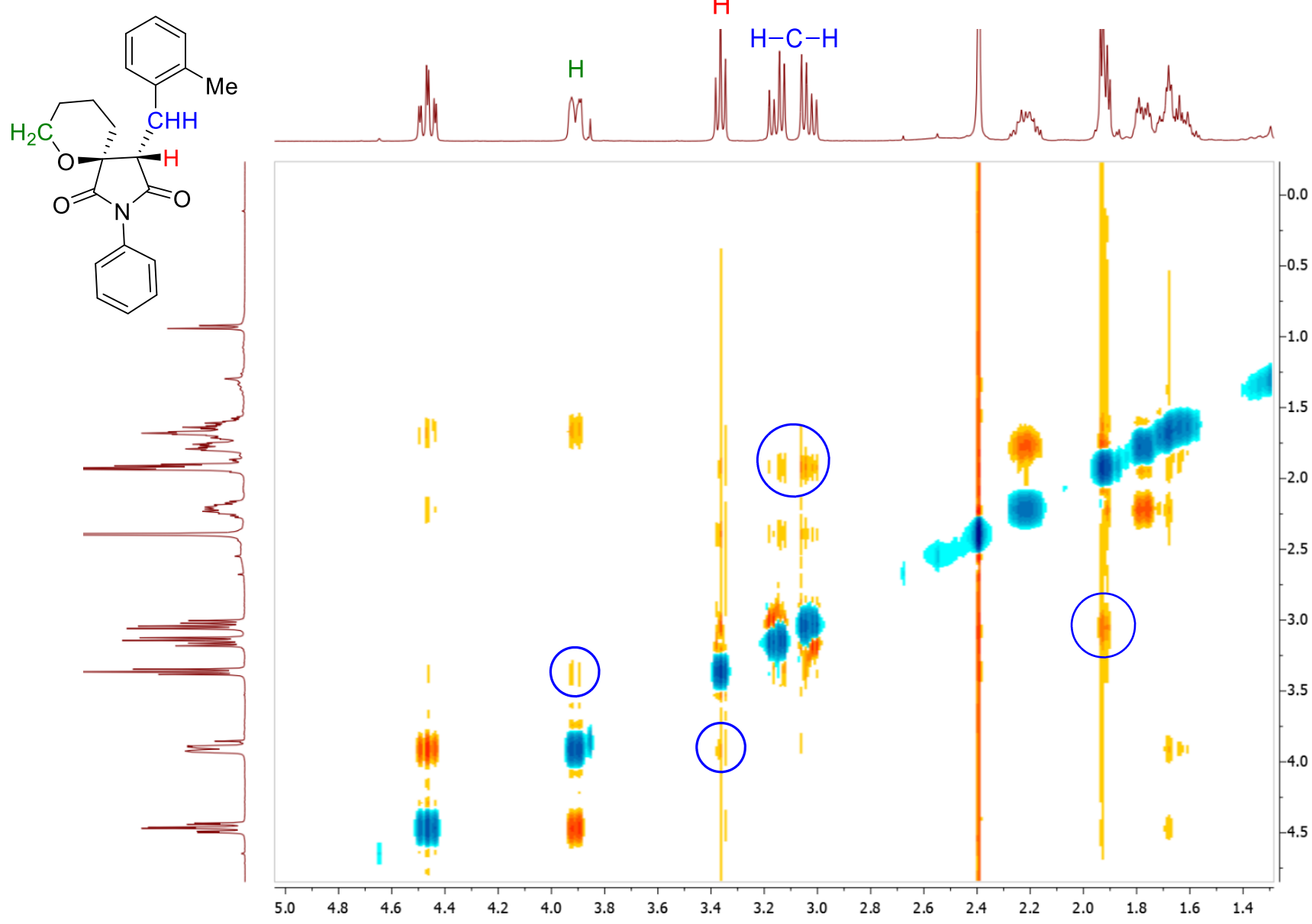


Copies of ${ }^{1} \mathrm{H}\left(400.13 \mathrm{MHz}, \mathrm{CDCl}_{3}\right)$ and ${ }^{13} \mathrm{C}\left(100.61 \mathrm{MHz}, \mathrm{CDCl}_{3}\right)$ spectra of $(\boldsymbol{R} / \boldsymbol{S}, \boldsymbol{S} / \boldsymbol{R})-\mathbf{1 7} \mathbf{g}$
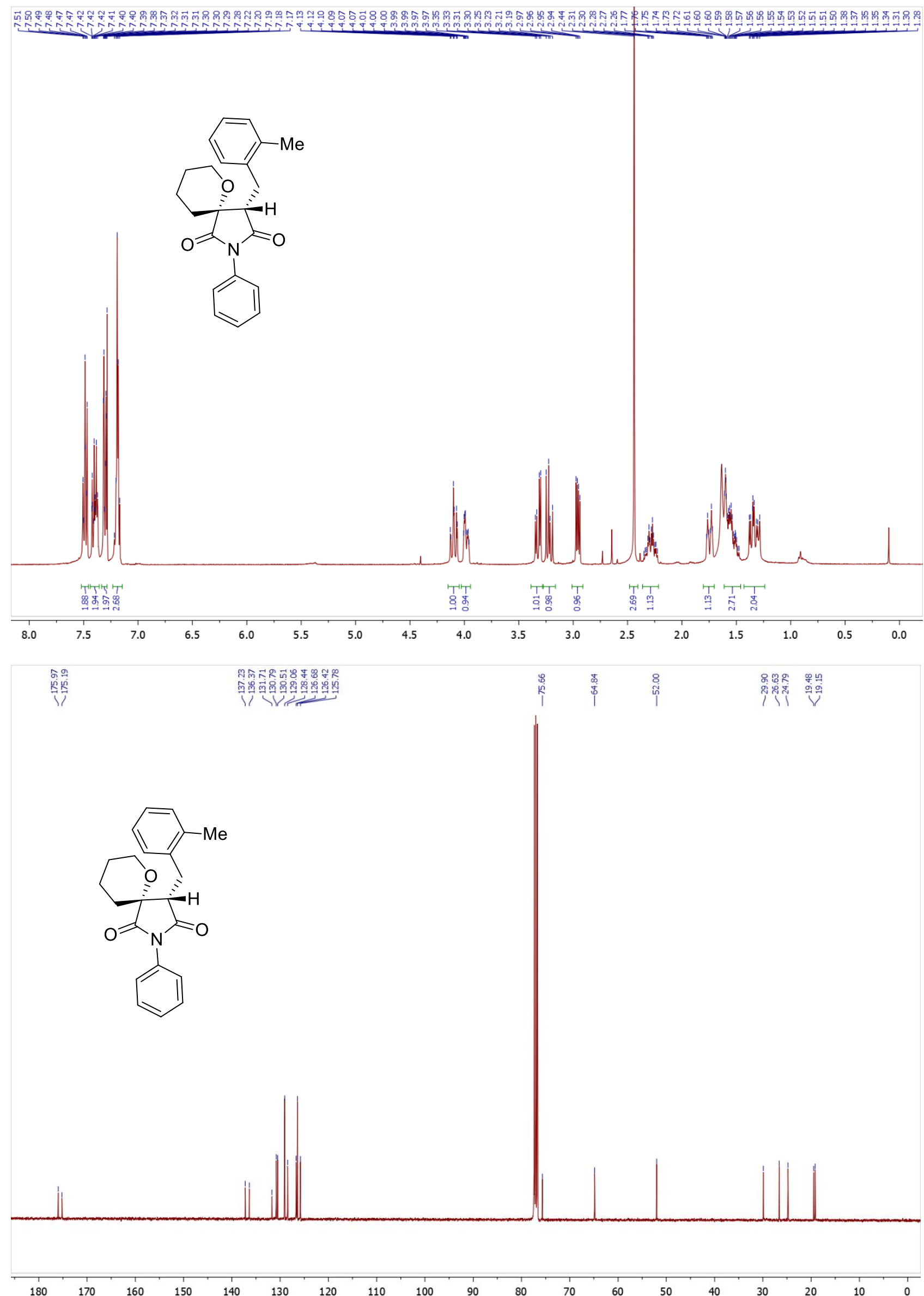
NOESY (400.13 MHz, $\left.\mathrm{CDCl}_{3}\right)$ spectrum of compound $(\boldsymbol{R} / \boldsymbol{S}, \boldsymbol{S} / \boldsymbol{R}) \mathbf{- 1 7} \mathbf{g}$

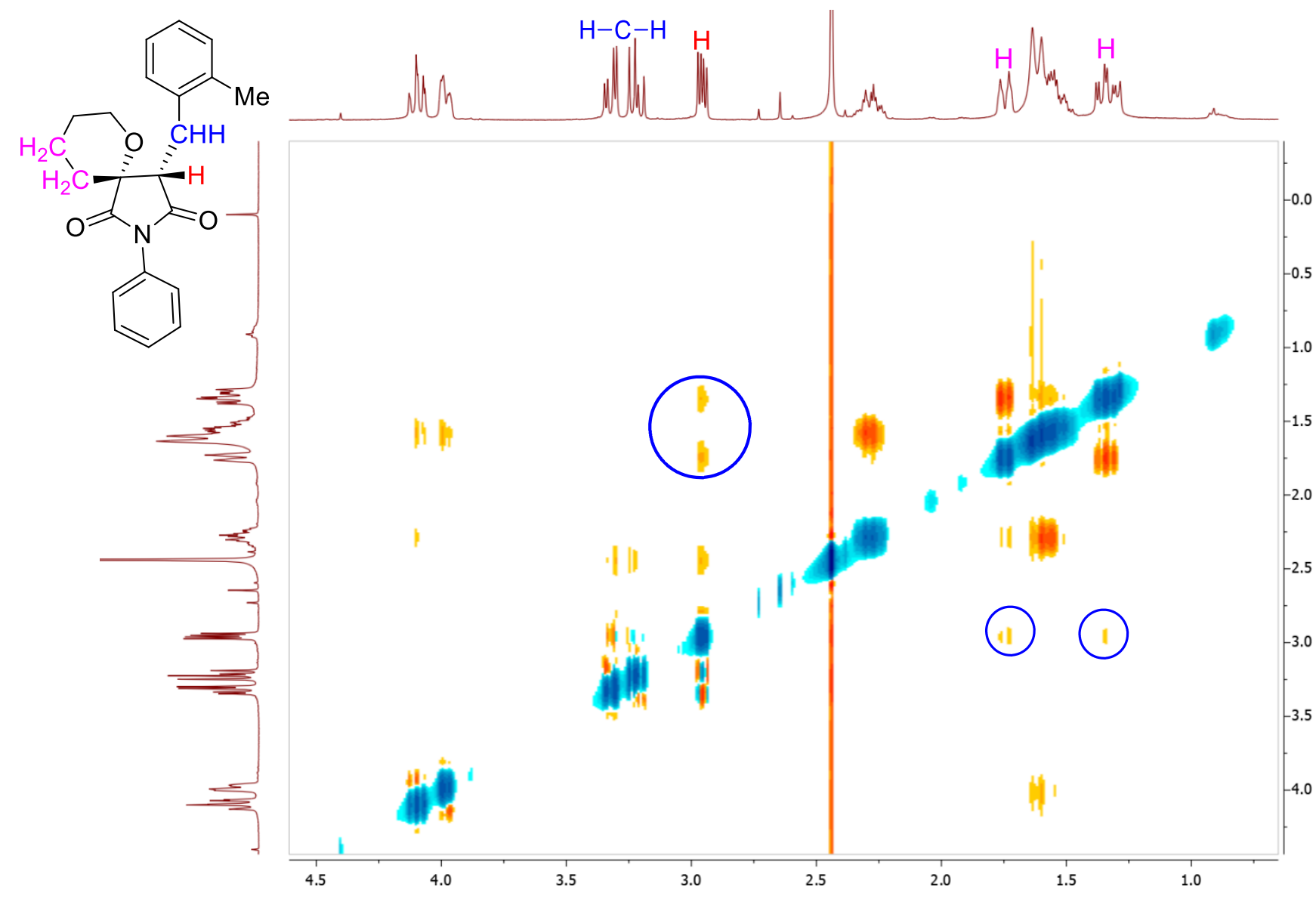


Copies of ${ }^{1} \mathrm{H}\left(400.13 \mathrm{MHz}, \mathrm{CDCl}_{3}\right)$ and ${ }^{13} \mathrm{C}\left(100.61 \mathrm{MHz}, \mathrm{CDCl}_{3}\right)$ spectra of $(\boldsymbol{R} / \mathbf{S}, \boldsymbol{R} / \boldsymbol{S})-\mathbf{1 7} \mathbf{x}$

它员员是 영
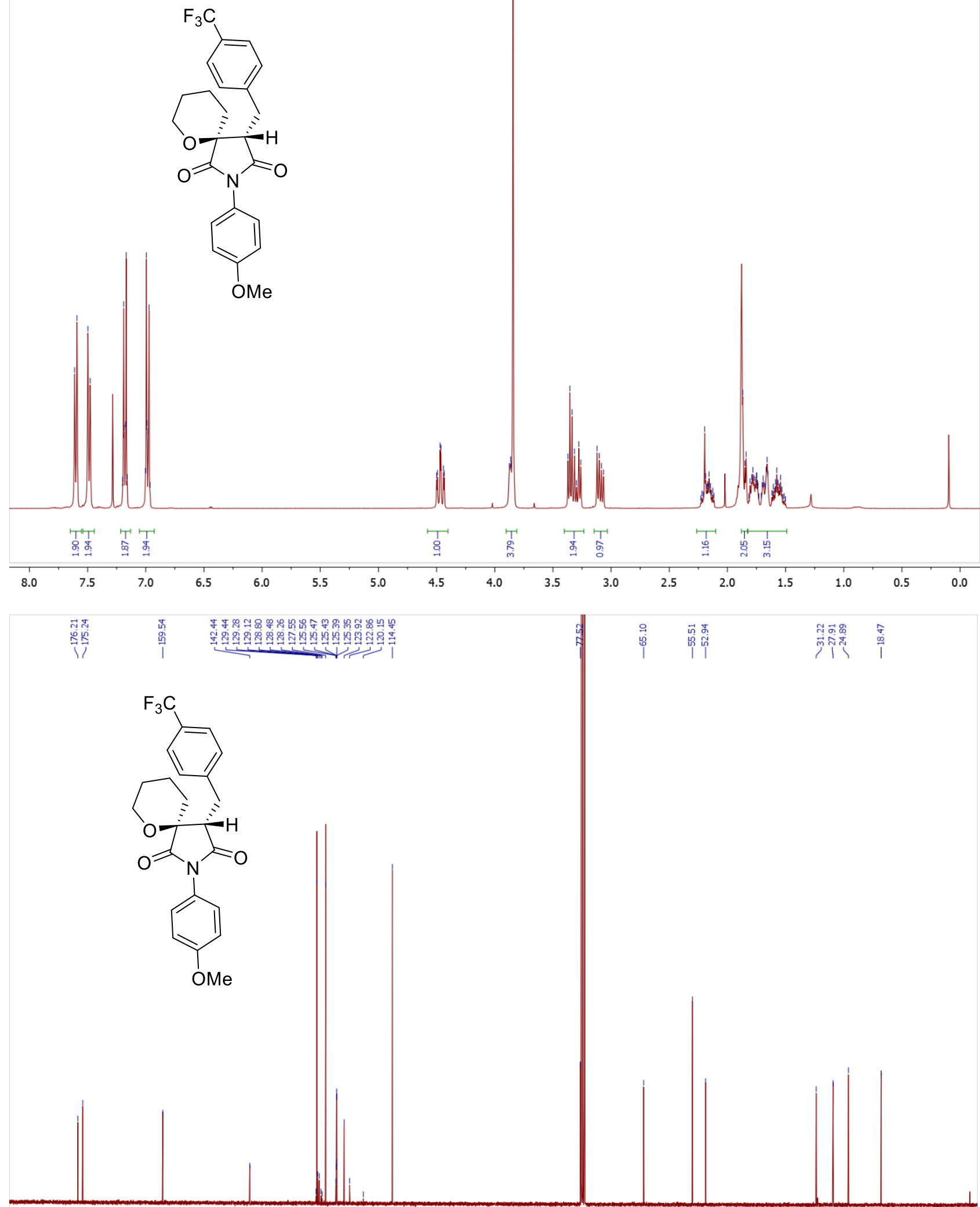

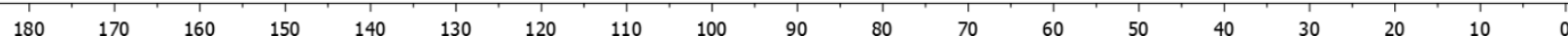


Copy of ${ }^{19} \mathrm{~F}\left(376.50 \mathrm{MHz}, \mathrm{CDCl}_{3}\right)$ spectrum of $(\boldsymbol{R} / \boldsymbol{S}, \boldsymbol{R} / \boldsymbol{S})-\mathbf{1 7} \mathbf{x}$

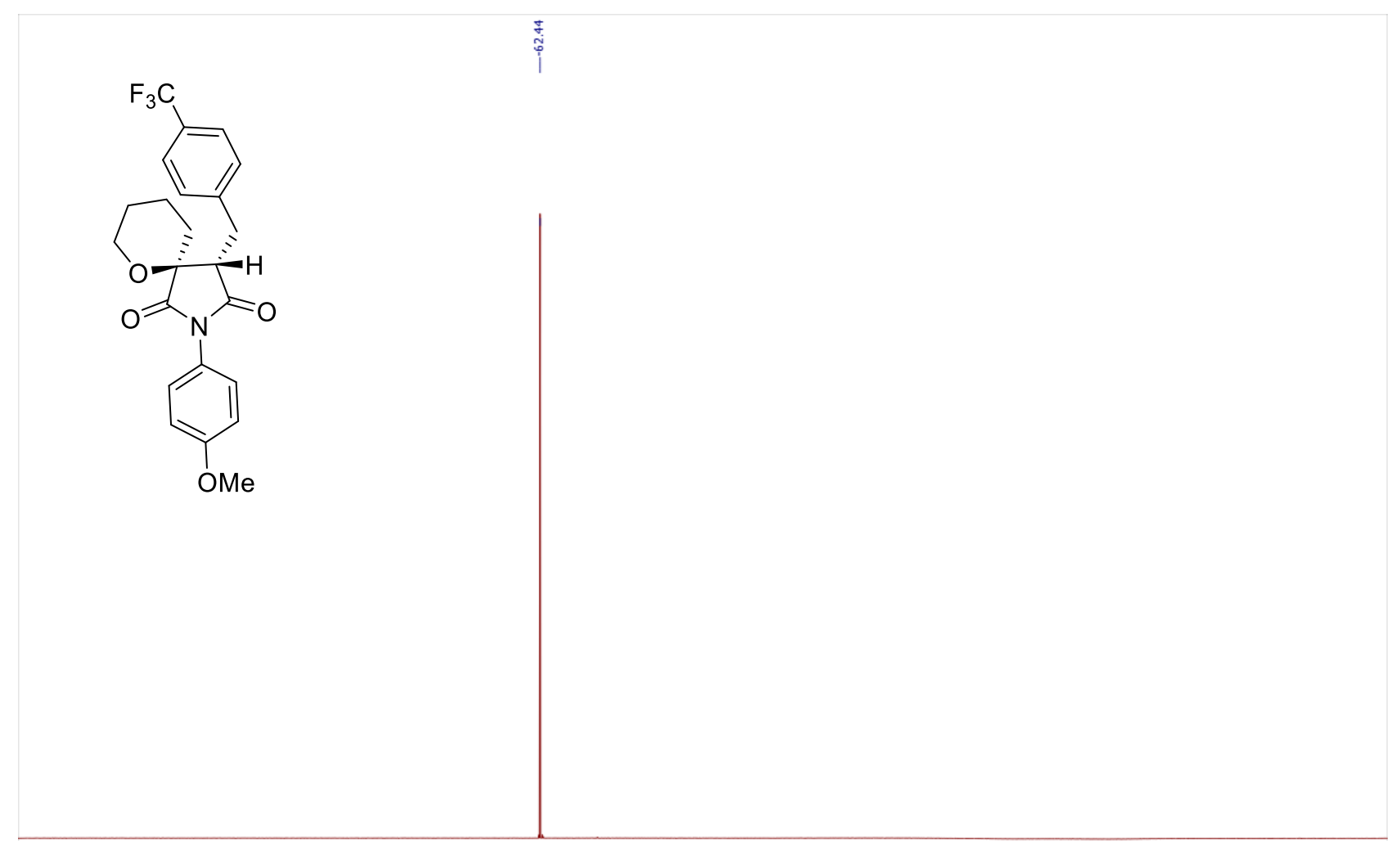

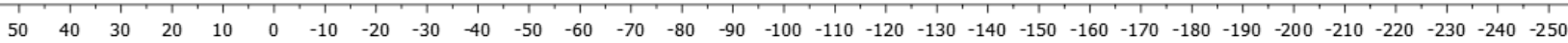

NOESY (400.13 MHz, $\left.\mathrm{CDCl}_{3}\right)$ spectrum of compound $(\boldsymbol{R} / \boldsymbol{S}, \boldsymbol{R} / \boldsymbol{S})-\mathbf{1 7} \mathbf{x}$

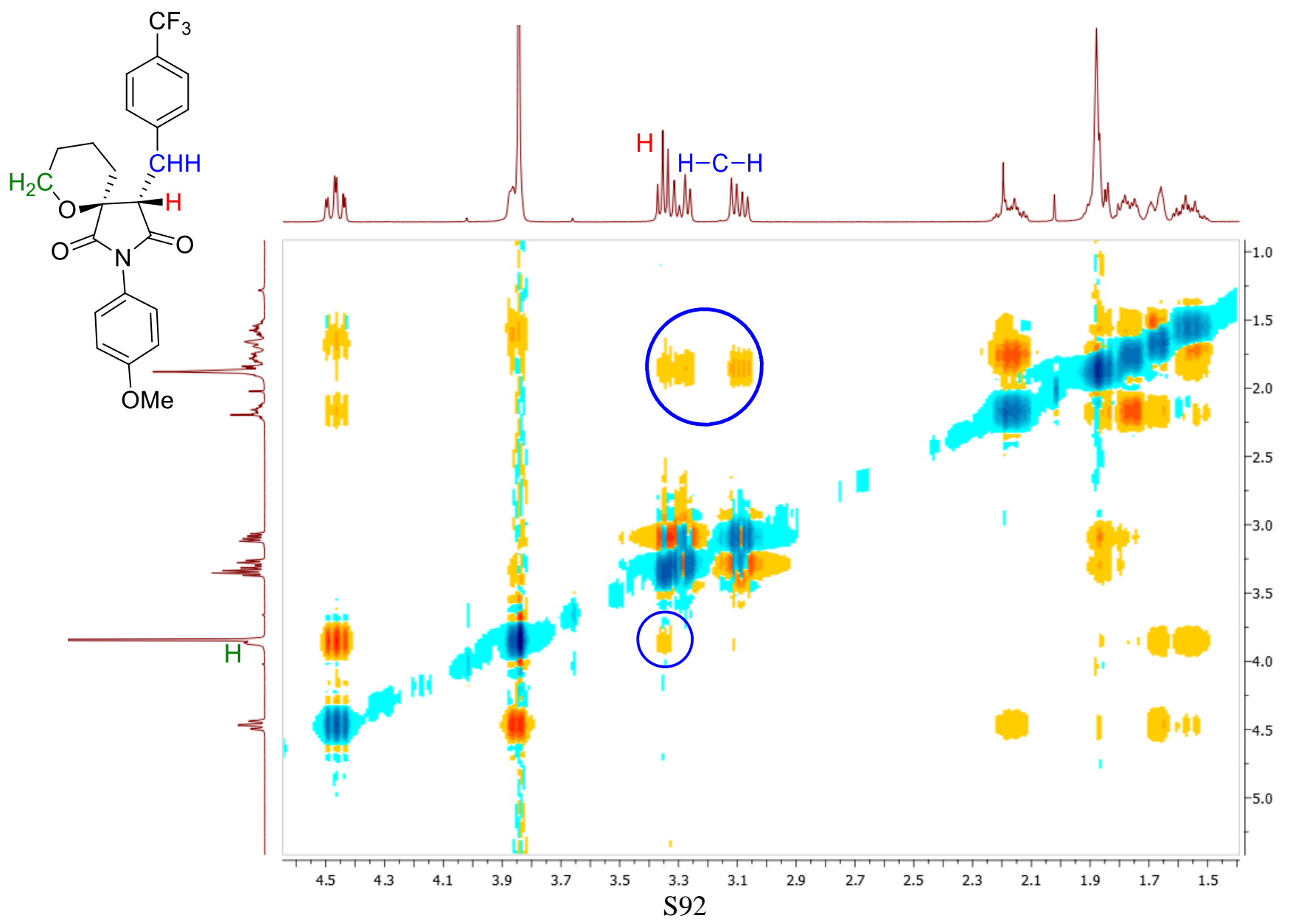


Copies of ${ }^{1} \mathrm{H}\left(400.13 \mathrm{MHz}, \mathrm{CDCl}_{3}\right)$ and ${ }^{13} \mathrm{C}\left(100.61 \mathrm{MHz}, \mathrm{CDCl}_{3}\right)$ spectra of $(\boldsymbol{R} / \mathbf{S}, \mathbf{S} / \boldsymbol{R})-\mathbf{1 7} \mathbf{x}$

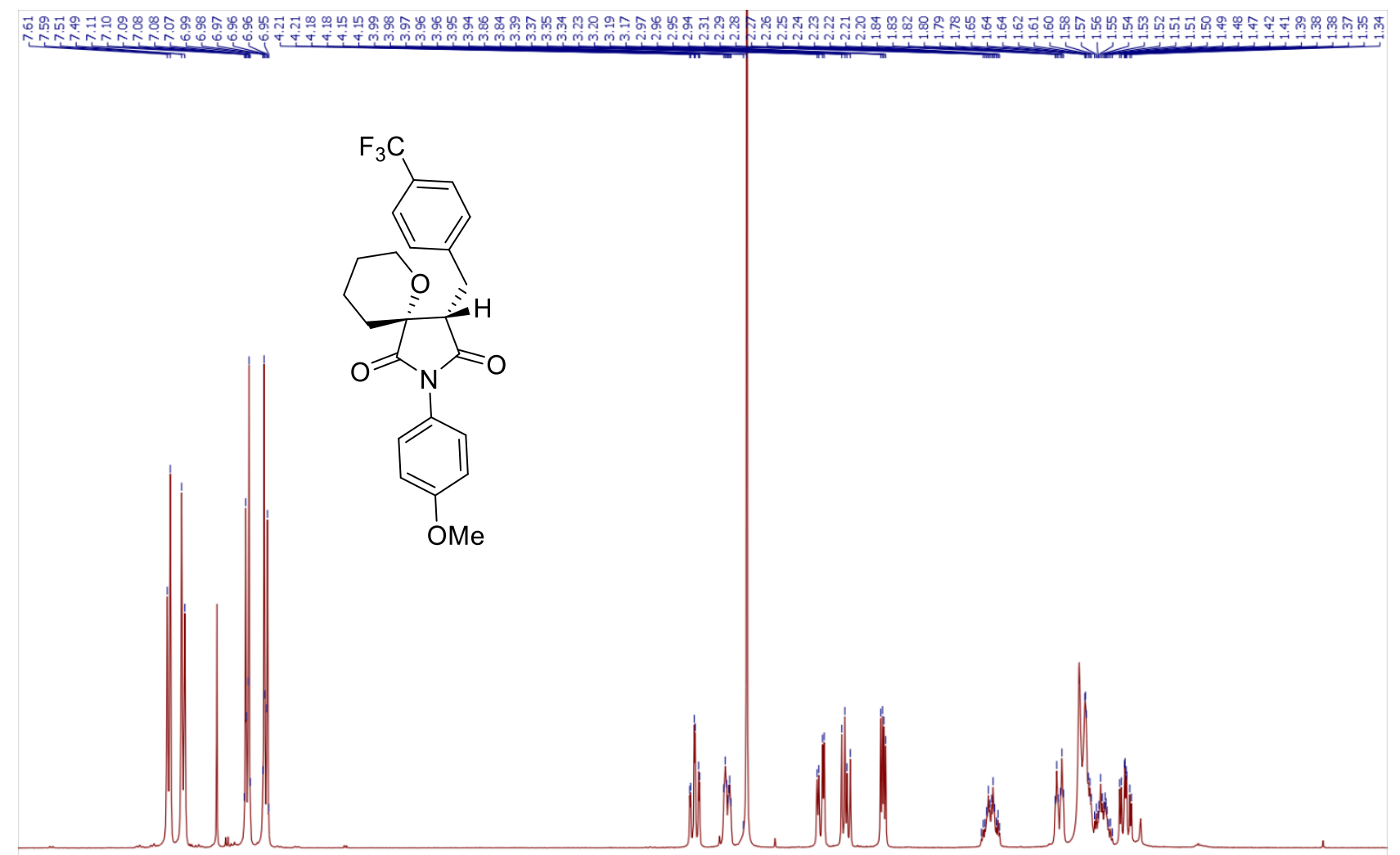

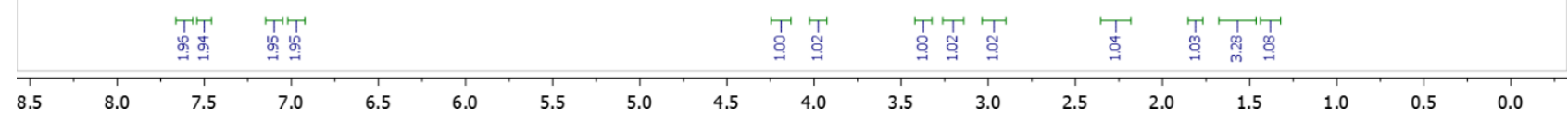

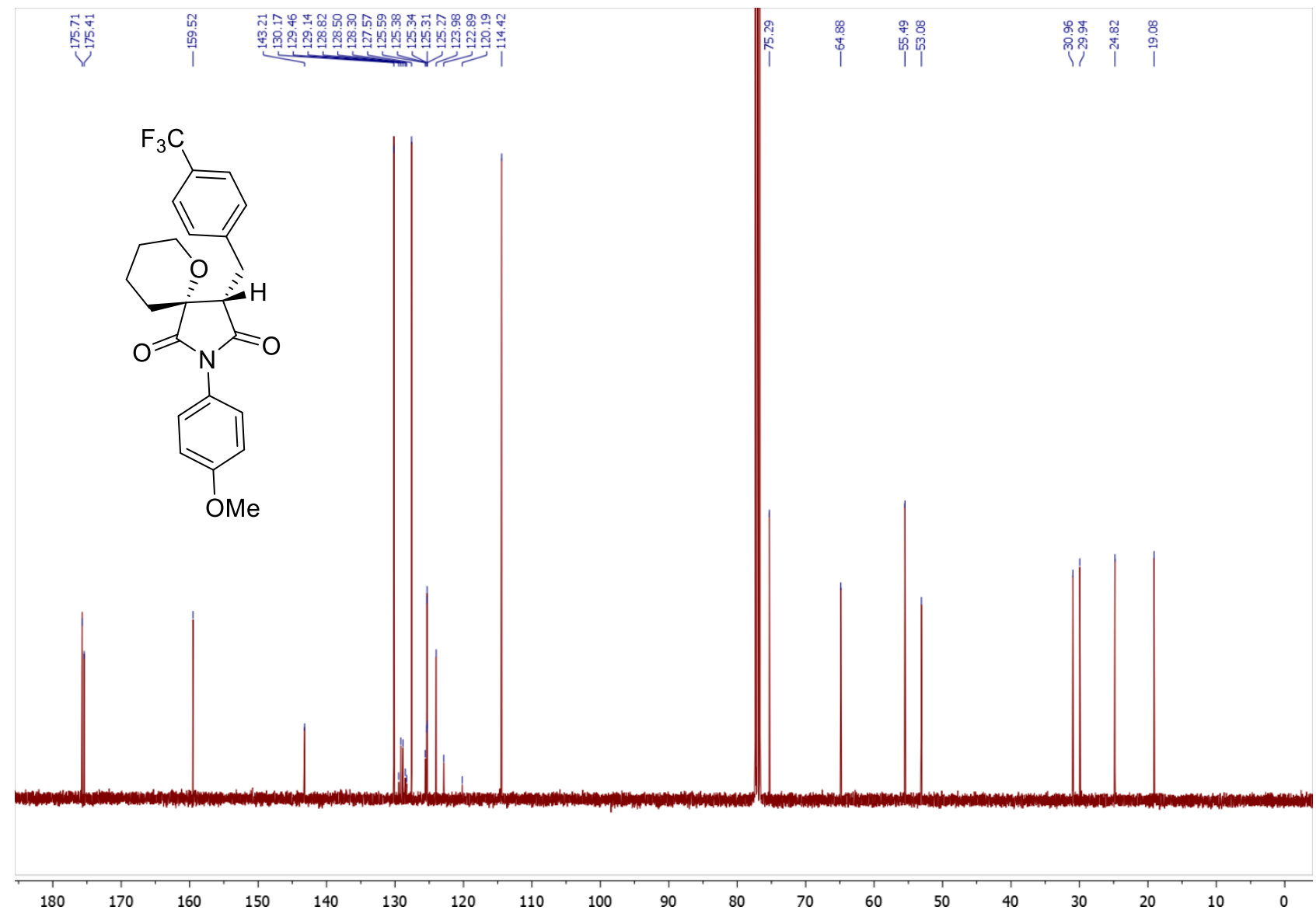


Copy of ${ }^{19} \mathrm{~F}\left(376.50 \mathrm{MHz}, \mathrm{CDCl}_{3}\right)$ spectrum of $(\boldsymbol{R} / \mathbf{S}, \mathbf{S} / \boldsymbol{R})-\mathbf{1 7} \mathbf{x}$

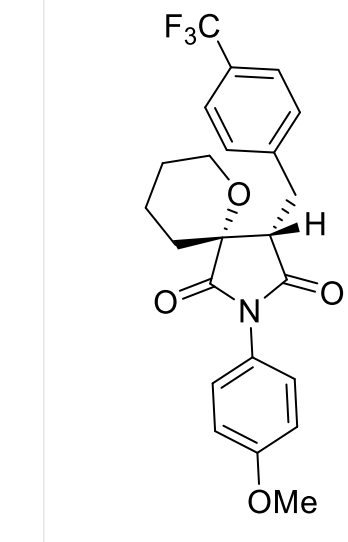

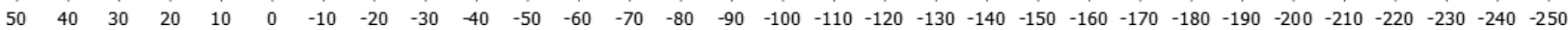

NOESY $\left(400.13 \mathrm{MHz}, \mathrm{CDCl}_{3}\right)$ spectrum of compound $(\boldsymbol{R} / \mathbf{S}, \mathbf{S} / \boldsymbol{R})-\mathbf{1 7} \mathbf{x}$

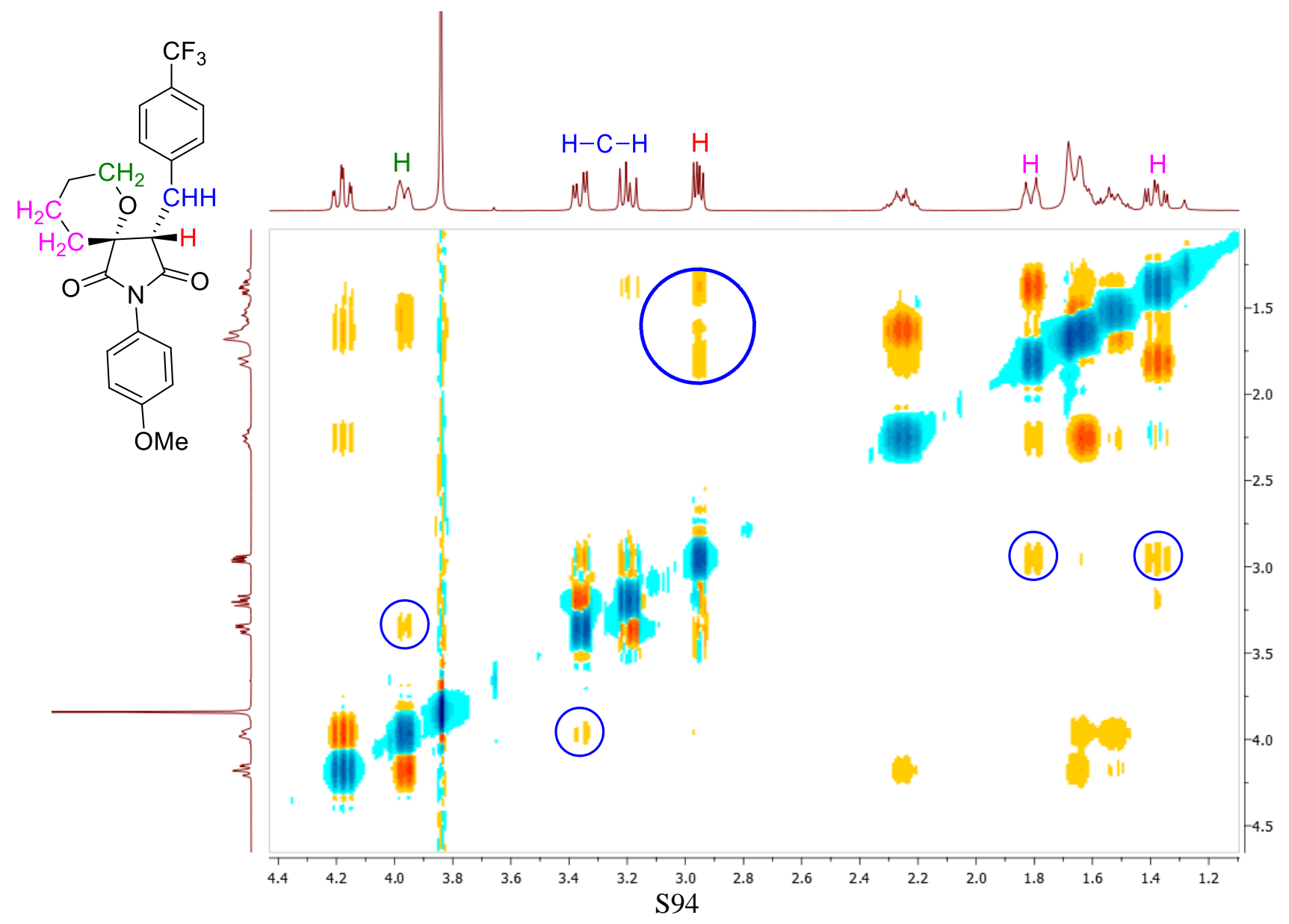

